Portland State University

PDXScholar

$1-1-1985$

\title{
Collective bargaining: a process adopted by Oregon's four-year institutions of higher education to support faculty members' participation in institutional governance
}

Patricia Lillian Chadwick

Portland State University

Follow this and additional works at: https://pdxscholar.library.pdx.edu/open_access_etds Let us know how access to this document benefits you.

\section{Recommended Citation}

Chadwick, Patricia Lillian, "Collective bargaining: a process adopted by Oregon's four-year institutions of higher education to support faculty members' participation in institutional governance" (1985).

Dissertations and Theses. Paper 457.

https://doi.org/10.15760/etd.457

This Dissertation is brought to you for free and open access. It has been accepted for inclusion in Dissertations and Theses by an authorized administrator of PDXScholar. Please contact us if we can make this document more accessible: pdxscholar@pdx.edu. 


\section{COLLECTIVE PARGAINING: A PROCESS ADOPTED BY OREGON'S FOUR-YEAR INSTITUTIONS OF HIGHER EDUCATION TO SUPPORT FACULTY MEMBERS' PARTICIPATION IN INSTITUTIONAL GOVERNANCE}

by

PATRICIA LILLIAN CHADWICK

A dissertation submitted in partial fulfillment of the requirements for the degree of

DOCTOR OF EDUCATION

in

PUBLIC SCHOOL ADMINISTRATION AND SUPERVISION

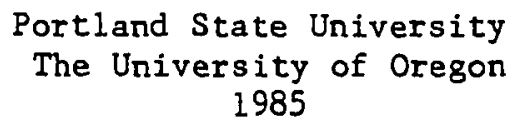

(c) 1985 Patricia L. Chadwick 
TO IIHE OFFICE OF GRADUATE STUDIES AND RESEARCH:

The members of the Committee approve the dissertation of Patricia Lillian Chadwick presented May 22, 1985.

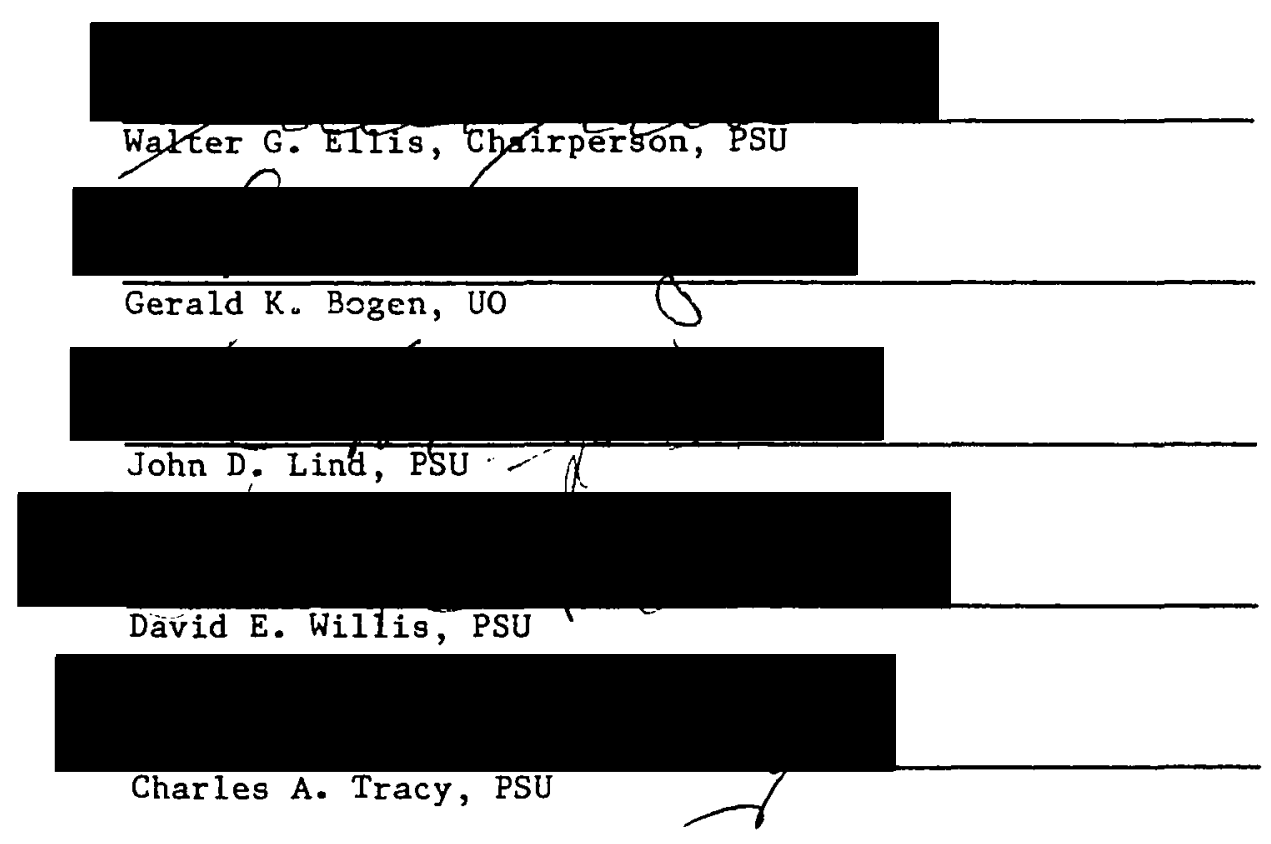

APPROVED

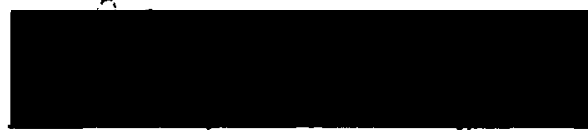

George V. Guy, Bi-University Program Coordinator, Portland State University

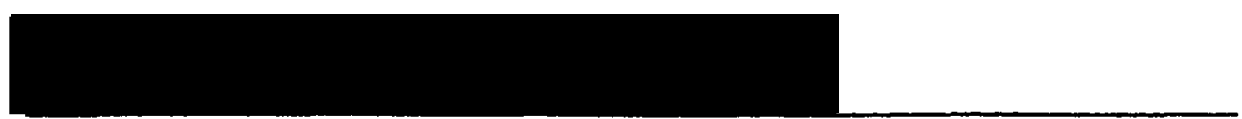

Richard A. Schmuck, Bi-University Program Coordinator, University of Oregon

Donald J. Leu, fean of the School of Education, Portland State University

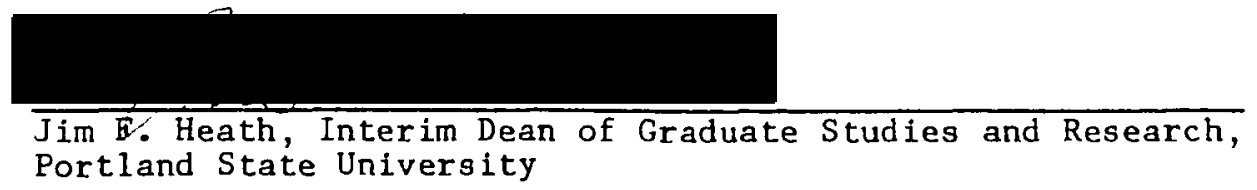


AN ABSTRACT OF THE DISSERTATION OF Patricia Lillian Chadwick for the Doctor of Education in Public School Administration and Supervision presented May 22, 1985.

Title: Collective Bargaining: A Process Adopted by Oregon's Four-Year Institutions of Higher Education To Support Faculty Members' Participation in Institutional Governance

APPROVED BY MEMBERS OF THE DISSERTATION COMMITTEE:

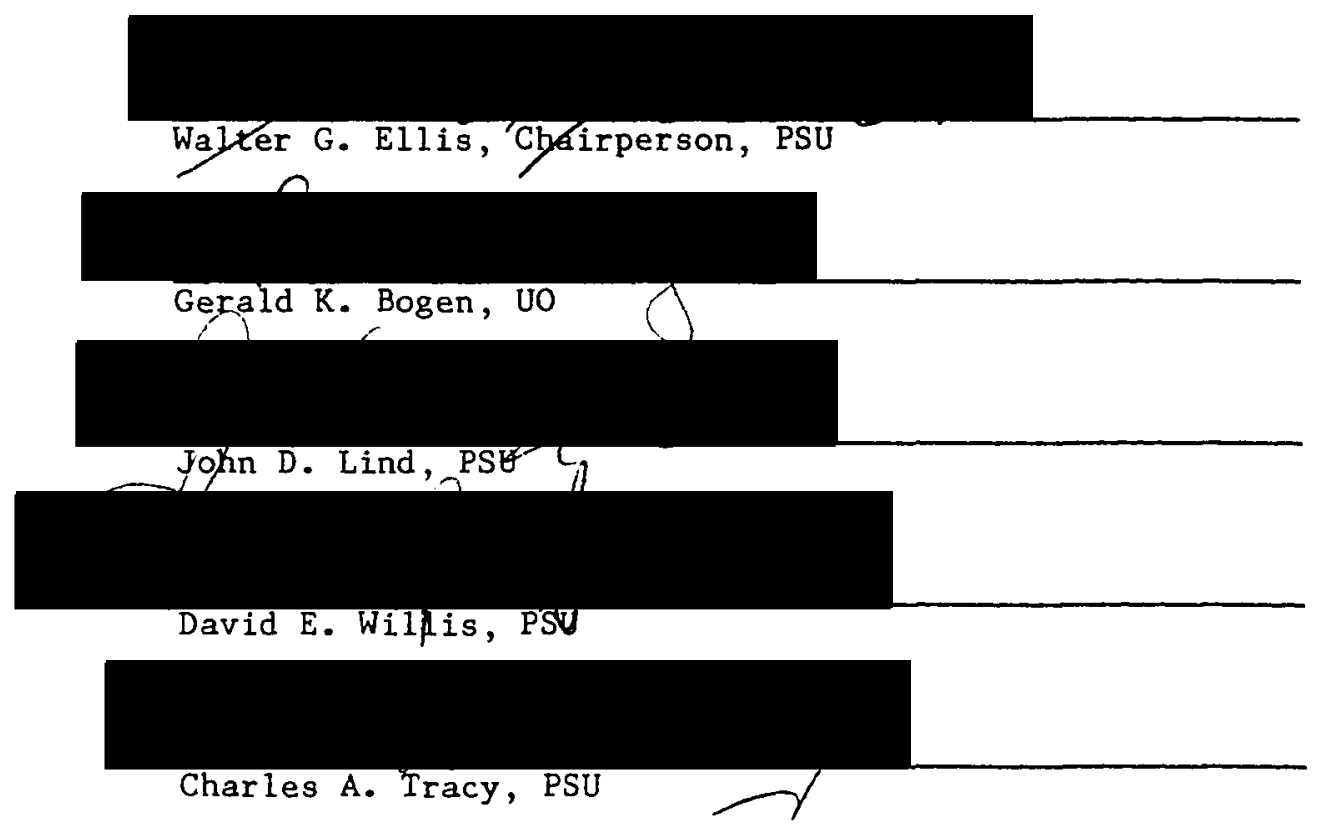

In 1966, amid hostile concerns and myths, the process of collective bargaining entered the university system of higher education. A dynamic social process grounded in the labor movement dating from the industrial revolution, it was intended not as an alternative to the traditional governance mode of the academy, but rather as a supplemental mode to support the advancement of faculty rights (Polishook, 1982). 
The purpose of this survey was to study select faculty members with an academic appointment in Oregon's 4-year unionized institutions of higher education to evaluate whether or not they perceive the process of collective bargaining as supportive of faculty members' rights to participate in institutional governance.

The population of the study consisted of 694 faculty members holding an academic appointment in one of Oregon's 4-year unionized institutions during the spring of 1984. Those faculty members selected for the study must (1) have held a full-time faculty appointment during the academic year, (2) have been employed in the present institution for a minimum of five years, and (3) have or be on a tenure track appointment in the department.

The research instrument "A Questionnaire to Study Collective Bargaining As a Process Adopted In Oregon's 4-Year Institutions of Higher Education to Provide for Faculty Members' Participation in Institutional Governance" was used to measure for faculty members' perception of collective bargaining as a supplemental governance mode in their university system in three major areas: (1) Respondent Information, (2) Institutional Information, and (3) Institutional Governance Information.

For this study, it was hypothesized that collective bargaining would support the rights of faculty members with academic appointments in Oregon's 4-year institutions of higher education to participate in institutional governance. The four hypotheses were: 
H:I The collective bargaining process has affirmed the professional interests of the academician with an appointment in Oregon's 4-year institutions of higher education.

$\mathrm{H}: 2$ Collective bargaining, as implemented in Oregon's 4-year institutions of higher education, has provided for the academicians' participation in the planning and policy-making process related to the economic interests of the institution.

H:3 Faculty members with an academic appointment in Oregon's 4-year unionized institutions of higher education participate in determining the institution's educational policy on academic issues.

H:4 Collective bargaining has provided the faculty members in Oregon's 4-year institutions of higher education with the opportunity to participate in determining the academic and personnel policies of their employment.

The Kruskal-Wallis one-way analysis of variance was used to test each of the four hypotheses of the study. Although statistically significant differences at the 0.05 level were found within each dependent variable subset of data: (1) professional interests, (2) economic interests, (3) educational policies, and (4) academic/personnel policies, the four hypotheses of the study were rejected. The data, however, suggest that the respondents at all three of the subject institutions perceive collective bargaining to have provided for (1) a formalized structure and process for institutional decision-making and (2) the opportunity to make policy decisions for the two important issues of (a) dismissal for cause and (b) grievance procedures. 
These are important results, even though the aggregate data suggest that academic collective bargaining in Oregon's 4-year institutions of higher education has not been perceived as having provided faculty members with the right to participate in many institutional governance issues. 
Dedication

This dissertation is dedicated to my father, Mr. Virgil James Clark, and to my niece, Deanna Marie Duyck 
ACKNOWLEDGMENTS

I would like to express my sincere gratitude to the members of my dissertation committee, Dr. Walter G. Ellis, Chairperson, Dr. Gerald K. Bogen, Dr. John D. Lind, Dr. David E. Willis and to Dr. Charles A. Tracy, the Graduate School Representative to the committee. Throughout the process of completing the dissertation, as well as at my oral examination and defense, they so generously shared their expertise as educators and scholars.

I will always be particularly grateful to my chairperson, Dr. Walter G. Ellis, for the excellent guidance and support that he provided me as I worked to reach this important professional goal. 
TABLE OF CONTENTS

PAGE

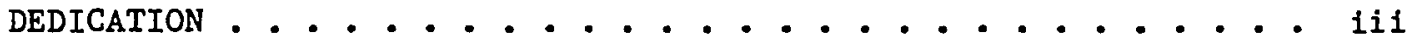

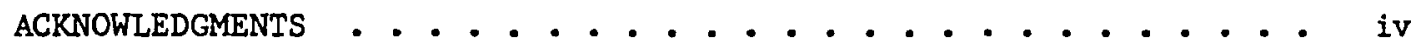

LIST OF TABLES . . . . . . . . . . . . . . . . . . . . . . viil

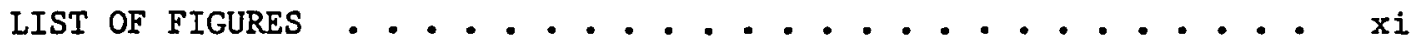

LIST OF APPENDICES . . . . . . . . . . . . . . . . . . . . . . xii

CHAPTER

I. INTRODUCTION • . . . . . . . . . . . . . . . . 1

Purpose and Problems of the Study ............ 5

Hypotheses of the Study . . . . . . . . . . . . 6

Scope of the Study ..................... 7

Definition of Terms . . . . . . . . . . . . . . . 8

II. REVIEW OF THE LITERATURE . . . . . . . . . . . . . 10

The University Enterprise . . . . . . . . . . . 10

The Contemporary University Setting . . . . . . . . 10

Academic Professionalism . . . . . . . . . . . . 11

Academic Governance . . . . . . . . . . . . . . 12

A Conceptual Framework for the Traditional Mode of

Academic Governance . . . . . . . . . . 15

The Concept of Authority . . . . . . . . . . . 16

The Concept of Power . . . . . . . . . . . . 16

The Concepts of Authority and Power in Academia . . . 18

A Supplemental Governance Mode for the University . . . . 19 System

A Definition of Collective Bargaining . . . . . . . . 19

The Purpose of Collective Bargaining in Academia . . . 22

A Model for Academic Collective Bargaining . . . . . . 22

Patterns of Relationships in Academic Collective

Bargaining .. . . . . . . . . . . . . . 24

The Legal Framework for the Establishment of Academic

Collective Bargaining . . . . . . . . . . . 25

The Federal Sectors . . . . . . . . . . . . . 25

The Public Sectors . . . . . . . . . . . . . 29

State Labor Laws . . . . . . . . . . . . . . 29

Collective Bargaining and the University System . . . . . 31

The Entrance of Academic Bargaining into the

University System . . . . . . . . . . . . 31 
The Scope of Academic Collective Bargaining . . . . . 34 Academic Collective Bargaining Agents/Agreements . . 35 The Subject of Contract Negotiations in Academic

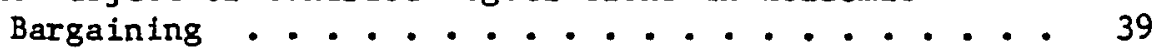
Collective Bargaining in the Oregon System of Higher Education: Focus on the 4-Year Institutions.... 44 The Effects of Academic Collective Bargaining in the University System ............. 45

III. RESEARCH METHODOLOGY AND PROCEDURES . . . . . . . . 50

Introduction . . . . . . . . . . . . . . 50

The Research Model: Synthesis of Theory and Fact . . . 50

Introduction ................. 50

Demographic Factors .............. 51

Contextual Factors .............. 54

Institutional Governance ............. 54

Professional Interest ............ 55

Economic Interest ............... 56

Educational Policies............ 57

Academic and Personnel Policies ........ 58

The Research Methodology .. . . . . . . . . 59

An Evaluative Survey .............. 59

Procedures for the Study .............. 61

The Research Instrument ............ 61

The Research Population ........... 64

The Data Collection ............ 65

The Data Analysis ........... 68

IV. PRESENTATION AND ANALYSIS OF THE DATA . . . . . . 69

Introduction ................ 69

Respondent Information............. 70

Years of Full-Time Teaching In a 4-Year Institution of Higher Education............ . 70

Membership in the American Association of University Professors ............. 71

Faculty Members' Involvement in Institutional Academic Collective Bargaining ......... 72

Age of the Respondent ............... 73

University/Departmental Academic Governance Bodies . . 74

Salary ................... . 76

Institutional Influences . . . . . . . . . . 79

Introduction ............... 79

Funding ............... 80

Decision-Making Processes .......... 81

Organizational Change ........... 86

Students . . . . . . . . . . . . . . 88

Institutional Governance Information ........... 88

Introduction ................ 88

Professional Interests ........... 90 
Economic Interests - . . . . . . . . . . . . 91

Educational Policies . . . . . . . . . . . . . 94

Academic and Personnel Policies . . . . . . . . . . 95

Data Analysis Specific to the Four Dependent

Variable Subsets . . . . . . . . . . . . . . 98

Hypothesis Testing. . . . . . . . . . . . . . 100

(H: 1) .................. 102

(H:2) ........................ 104

(H:3) ....................... 107

(H:4) ...................... 110

V. SUMMARY, CONCLUSION, RECOMMENDATIONS . . . . . . . . . . . 114

Summary of the Study . . . . . . . . . . . . . . 114

Conclusions of the Study . . . . . . . . . . . . . 117

Respondent Information . . . . . . . . . . . 117

Institutional Influences . . . . . . . . . . . 117

Hypotheses of the Study . . . . . . . . . . . . . 118

Professional Interests . . . . . . . . . . . 120

Economic Interests . . . . . . . . . . . . 120

Educational Policies . . . . . . . . . . . . 121

Academic and Personnel Pollcies... . . . . . . . 122

Recommendations . . . . . . . . . . . . . . . 122

Suggested Further Research . . . . . . . . . . . 122

Oregon System of Higher Education . . . . . . . . . 123

An Expanded Population . . . . . . . . . . . . 125

Closing Summary . . . . . . . . . . . . . 126

VI. REFERENCES . . . . . . . . . . . . . . . . . . 127 
I. A Comparison of the Three Basic Contingency Models . . . 18 of Academic Governance

II. A Summary of the Major Executive Orders Related to . - . 28 Labor-Management Relationship in Federal Unions and Agency Management

III. A Sumnary of the Characteristics of the Major Laws . . 32 Enacted in the Public Sector by 1978

IV. Growth of Unionization in Higher Education the . . . . 35 Public and Private Sector, 1974-1983

v. Recognized Bargaining Agents January, 1984 . . . . . 36

VI. Academic Agreement, January, 1984 . . . . . . 36

VII. The Major National Organizations As Representatives . - 38 of 4-Year Institutions in Collective Bargaining Negotiations

VIII. Analysis of Bargaining Agents and Collective Bar- .. • 39 gaining Agreements

IX. The Specific Issues Relative to the Five Major Cate- . 43 gories of Academic Contract Negotiations

X. Distribution of Identified Population for the Re- . . 65 search Study in Oregon's Three Unionized 4-Year Institutions of Higher Education

XI. Distribution of Questionnaire Responses Received Ac- . . 67 cording to Each Wave By Employing 4-Year Unionized Institutions of Higher Education in Oregon

XII. Distribution of the Profile Characteristic Data . . . 68 of the Non-Respondents

XIII. Distribution of Respondents by Employing Institution . . 71 and Years of Full-Time Teaching In a 4-Year Institution of Higher Education.

XIV. Distribution of Respondents by Employing Unionized . . . 72 Institution and Membership in (AAUP) American Association of University Professors 
$\mathrm{XV}$. Levels of Involvement in the Collestive Bargaining . . 72 Process by Institution

XVI. Institutional Distribution of Respondents by Age . . . 73 Range

XVII. Distribution of Respondents by Academic Rank and Age . . 74 Range

XVIII. Distribution of Respondents by University/Depart- . . 75 mental Governance Bodies and the Employing Institution

XIX. Distribution of Respondents by Academic Rank and . . . 76 University/Departmental Academic Governance Committees

XX. Distribution of Faculty Salaries . . . . . . . 77

XXI. Salary Distribution for Faculty Respondents by . . . 78 Employing Academic Institution

XXII. Distribution of Salary by Academic Ares for . . . . 78 Faculty Respondents

XXIII. Salary Interval Distribution of Faculty Respondents . . 79 by Academic Rank

XXIV. Faculty Members' Perceptions of Institutional . . . 165 Influences Related to their Decision-Making to Vote for a 1983 Contract Renewal

XXV. Distribution of Respondents' Answers to Questions . . 82 8 and 11 of the Research Instrument by the Employing Academic Setting

XXVI. Distribution of Respondents' Answers According to . . 84 Questions 14 and 16 of the Research Instrument by Employing Academic Institution

XXVII. Distribution of Faculty Responses to Questions 13 . . 85 and 15 of the Research Instrument by Employing Academic Institution

XXVIII. Distribution of Faculty Responses to Questions . . . . 86 10,18 and 19 of the Research Instrument by Employing Academic Institution

XXIX. Distribution of Faculty Responses to Questions 7 and .. 17 of the Research Instrument by Employing Academic Institution. 
XXX. Faculty Members' Perception of the Impact of . . . . 168 Academic Collective Bargaining on Their Professional Interests In Institutional Governance

XXXI. Faculty Members' Perceptions of the Impact of . . . . 92 Academic Collective Bargaining on Institutional Structure/Process

XXXII. Faculty Members' Perceptions of the Impact of . . . . 170 Academic Collective Bargaining on Economic Interests in Institutional Governance

XXXIII. Institutional Respondents' Perception to Selected . . 93 $(29,30,31$ or 34$)$ Statements Related to Economic Interest in Academic Governance

XXXIV. Faculty Members' Perceptions of the Impact of Aca- . . 96 demic Collective Bargaining on Educational Policy Determinants in Institutional Governance

XXXV. Faculty Respondents' Perception of the Impact of . . . . 97 Collective Bargaining on Academic and Personnel Policies of Institutional Governance

XXXVI. Population Values for the Sum Scores......... 99

XXXVII. Characteristics For the Dependent Variable Sub-Sets . . 100 According to Sun Score

XXXVIII. Kruskal-Wallis Statistic P-values for the ...... 101 Variables

XXXIX. Simultaneous Comparisons of Sub-Group Means for . . . 102 Faculty Respondents' Perceptions of Academic Collective Bargaining and Professional Interest Issues.

XL. Simultaneous Comparisons of Sub-Group Means for . . . 105 Faculty Respondents' Perception of Academic Collective Bargaining and Economic Interest Issues

XLI. Simultaneous Comparisons of Sub-Group Means for . . . 108 Faculty Respondents' Perception of Academic Collective Bargaining and Educational Interest Issues

XLII. Simultaneous Comparisons of Sub-Group Means for . . . 111 Faculty Respondents' Perception of Academic Collective Bargaining and Academic/Personnel Interest Issues 


\section{LIST OF FIGURES}

FIGURE

PAGE

1. The General Labor-Relations Model ... . . . . . 23

2. The General Patterns of Labor-Management Relationships . . 24

3. The Research Model ............... 52

4. The Dependent Variable Set of the Research Mode1 . . . . 55 
Findings Specific to the 1969 Carnegie Commission • 147 on Higher Education Survey

C Human Subjects Research Review Committee Approval • 149 Letter

D Data Collection Information Letter from the Office . . 151 of Institutional Research Office at Portland State University Institutional Approval Letter for Data Collection . 153 Collection

G Follow-Up Appeal Material to Subjects for Waves . . 158 Two and Three of the Data Collection

Respondent Codebook for the (SPSS ${ }^{\mathrm{X}}$ ) Data ...... 161 Analysis

I Table XXIV: Faculty Members' Perceptions of . . . . 166 Institutional Influences Related to the DecisionMaking to Vote for a 1983 Contract Renewal Impact of Academic Collective Bargaining on Their Professional Interests In Institutional Governance 


\section{Chapter I}

INTRODUCTION

The contemporary American university system emerged in the $1960 \mathrm{~s}$ as a powerful societal force, with economic and political influence, as well as a substantive concentration of resources and multipurpose capacity (Sherman \& Loeffler, 1971; McHugh, 1973). As an enterprise, the university system was described by Clark Kerr in 1963 as:

A major producer, wholesaler and retailer in the knowledge industry, which was inextricably related to national growth and the well-being of society, as well as a major instrument of societal purpose (Kerr, 1963).

During the "era of growth" in the university system of higher education, the role of university teacher was professionalized. This status provided the academician with the professional autonomy required to participate in academic governance through ( 1 ) the setting of performance standards, (2) the regulation of terms and conditions of employment, and ( 3 ) the setting and regulation of academic standards and procedures for undergraduate and graduate education (Shulman, 1979). Furthermore, the academician's right to shared authority, as the traditional mode of academic governance, was developed and sustained in higher education, according to J. Victor Baldridge because:

(a) Faculty had the direct flow of its members into 
administrative positions;

(b) Departmental members developed educational programs for students and faculty, hired faculty, and set the standards of performance.

(c) Academic senates were formed to provide for influence/advice to the administration in institution-wide matters (Baldridge, 1982).

While the administration and faculty members were firmly committed to the concept of shared authority in the higher education enterprise, it was a brief golden age for the traditional mode of academic governance (Garbarino, 1973, 1975).

The mid-1960s brought a combination of contextual factors, both external and internal to the university system, which affected the governance structures and function of the academy (Garbarino, 1973). Among these factors were three major events: (1) the increase in campus size and in the number of colleges and universities, (2) increased financial problems, and (3) federal regulation that reduced the faculty members' influence in academic governance through departmental or campus-wide structures (Shulman, 1979).

By 1966 , as a consequence of these events, academic collective bargaining emerged as a supplemental governance mode for the academy. It was a mode of governance that was not intended as an alternative to the traditional governance forms of the university system but rather as a supplemental mode that would guarantee the advancement of faculty governance rights (Polishook, 1982).

A dynamic social process, grounded in a labor movement dating 
from the industrial revolution, collective bargaining has made enormous gains in higher education (Nelson, 1982). During the past 17 years, amid initial hostile concerns and myths, the process has Increased in public and private 4-year institutions of higher education. As Irwin H. Polishook (1982) stated: "The proportion of academic professionals who have voluntarily joined unions is greater than the proportion of other Americans who have joined unions (Polishook, 1982; Nelson, 1982).

In the university system, the growth of academic collective bargaining has been assured because of a well-defined legal environment, with established laws as the basis for federal and state sector employee negotiation (Hedgepeth, 1974). Although federal sector bargaining laws are an important part of the legal framework, the enactment of state regulative laws, which include comprehensive and permissive legislation, is of particular significance to education, according to Joseph W. Garbarino:

Education is a function basically of the states. While the degree of encouragement among states varies greatly, permissive state legislation is the key explanation for the burst of academic unions of the late 1960 s and early 1970 s (Garbarino, 1973).

By 1973, Oregon was among the original eight states to have enacted significant comprehensive bargaining laws for the educator as a public employee. These laws permitted faculty members with an appointment in an Oregon 4-year institution of higher education to select collective bargaining as a supplemental mode for their 
participation in institutional governance (Garbarino, 1973).

That choice has been confirmed by educational analysts such as Aussieker and Garbarino, Baldridge and Lee as the mode of governance adopted by academicians to improve or reinstate independence into their professional lives (Shulman, 1979). Furthermore, the recent scholarly works of Lee, Polishook and Kemerer/Baldridge have continued to support the position that faculty members have gained or maintained a substantive role in academic governance as a result of institutional unionization (Lee, 1979; Polishook, 1982; Baldridge, 1982). As Barbara A. Lee wrote in 1979:

Faculty as a whole gained formal governance powers through the union contract. Even on campuses where faculty have enjoyed considerable decision-making power, the contract legitimized and in many cases broadened the scope of faculty's governance rights (Lee, 1979).

In 1982, J. Victor Baldridge identified four positive trends in the formal governance rights of faculty members in university systems with academic collective bargaining. These trends, which support the formal governance powers gained by unionized faculty, are:

(1) The collective bargaining process standardized procedures in personnel practices for the academicians, with the benefits to them identified as: (a) order to the system, and (b) increased equity.

(2) The collective bargaining process helped the economic status of the profession. The bargaining process seems to have generated additional money. 
(3) The collective bargaining process resulted in the so-called

"dual track" relationship between faculty senates and unions, whereby senates serve faculty members' academic interests and unions serve their economic concerns, remaining viable at campuses that have both unions and senates.

(4) The collective bargaining process may be an incentive to the "decentralization" of administrative powers and authority (Baldridge, 1982).

Therefore, the research question arises: Has the adoption of collective bargaining as a supplemental governance mode by three of Oregon's 4-year institutions of higher education supported the rights of faculty members for participation in institutional governance?

\section{Purposes and Problems of the Study}

The purpose of this study was to investigate the faculty members with academic appointments in Oregon's 4-year unionized institutions of higher education to evaluate whether or not collective bargaining supports faculty members' rights to participate in institutional governance. To achieve the stated purpose, the following problems were investigated:

1. Have the professional interests of those academicians with an appointment in Oregon's 4-year institutions of higher education been affirmed through the collective bargaining process?

2. Has collective bargaining provided for the academicians' participation in financial planning and policy-making related 
to their economic interests as employees of an Oregon 4-year institution of higher education?

3. Do faculty members with an academic appointment in Oregon's 4-year unionized institutions of higher education participate in determining those institutional educational policies related to academic issues?

4. Has the collective bargaining process provided the faculty members in Oregon's 4-year institutions of higher education with the opportunity to participate in determining the academic and personnel policies of their employment?

\section{Hypotheses of the Study}

For this study, it was hypothesized that collective bargaining would support the rights of faculty members with academic appointments in Oregon's 4-year institutions of higher education to participate in institutional governance.

H:1 The collective bargaining process is perceived as affirming the professional interests of the academician with an appointment in Oregon's 4-year institutions of higher education.

H:2 Collective bargaining, as implemented in Oregon's 4-year institutions of higher education, has provided for the academicians' participation in the planning and policy-making process related to the economic interests of the institution.

H:3 Faculty members with an academic appointment in Oregon's 
4-year unionized institutions of higher education participate in determining the institution's educational policy on academic issues.

H:4 Collective bargaining has provided the faculty members in Oregon's 4-year institutions of higher education with the opportunity to participate in determining the academic and personnel policies of their employment.

\section{Scope of the Study}

The population of the study consisted of selected academicians holding an academic appointment in one of Oregon's 4-year unionized institutions in the spring of 1984. Those faculty members selected for the study must ( 1 ) have held a full-time faculty appointment during the 1983-84 academic year, (2) have been employed in the present institution for a minimum of five years, and (3) have or be on a tenure track appointment in the department.

The questionnaires for this study were sent to 694 faculty members with an appointment in Oregon's 4-year unionized institutions during the spring of 1984.

Data for the study were collected from the population of the study between May 21, 1984, and August 10, 1984. The research instrument, "A Questionnaire to Study Collective Bargaining As A Process Adopted in Oregon's 4-Year Institutions of Higher Education to Provide for Faculty Members' Participation in Institutional Governance," was used for the data collection (See Appendix A). 


\section{Definition of Terms}

For the purpose of this study, the following definitions of the major terms have been used:

1. Collective Bargaining -- Means the performance of the mutual obligation of a public employer and the representative of its employees to meet at reasonable times and confer in good faith with respect to employment relations, or the negotiation of an agreement, or any question arising thereunder, and the execution of a written contract incorporating any agreement reached if requested by either party. However, this obligation does not compel either party to agree to a proposal or require the making of a concession (Oregon, 1982).

2. Institutional Governance -- The formal structure and related activities that are used to make decisions affecting organizational relationships, procedures and policies (Duryea, Fisk, et al., 1973).

3. Academician -- An educator who holds an academic appointment in a 4-year institution of higher education.

4. Academy -- A 4-year university/college of higher education.

5. Contextual Factors -- These are a combination of issues, both external and internal to a university system of higher education, that affect the institutional governance structure and function (Garbarino, 1973).

6. Professional Interests -- A stature, gained during the 1960s, which provides the academician with the right to pursue the three central elements of the traditional academic model: (1) research, (2) peer evaluation, and (3) scholarship, as well as the right to autonomy in setting professional standards and regulating the terms 
and condịtions of employment (Shulman, 1979). (See questionnaire items: $20,21,22,23,24,25,26,27)$.

7. Economic Interests -- In a university system, faculty members are expected to participate, either directly or indirectly through structures of self-government within the institution, in the determination of policies and procedures related to economic issues. There are three types of such issues, those related to: (1) the total resources available to the institution, (2) the distribution of resources allocated to provide for the academician's economic security (e.g. salary, fringe benefits), and (3) the allocation of resources to major budgetary categories. (Brown, 1969; Wollett, 1971) (See questionnaire items: $28,29,30,31,32,33,34,35,36)$.

8. Educational Policies -- Are the written policies within a university system that govern the implementation of such academic issues as curriculum, degree requirements, or professional teaching. (See questionnaire items: $37,38,39,40,41,42,43$ ).

9. Academic and Personnel Policies -- Are provisions in the academicians' employment agreement related to a wide spectrum of bargaining subjects in the university system, which include such issues as academic duties, standards, personnel policies, and support services. (Wollett, 1971) (See questionnaire items: $44,45,46,47$, $48,49,50,51,52,53,54,55,56)$. 
Chapter II

REVIEW OF THE LITERATURE

The University Enterprise

\section{The Contemporary University Setting}

The late 1950 s and virtually all of the 1960 s have been described as the "golden years" of prosperity for American higher education (Garbarino, 1973). It was an "era of growth," which Joseph W. Garbarino in 1973 described as the direct result of a combination of factors external and internal to the system of higher education. The factors included:

An increase in the college-age population, the continued growth in the proportion of the relevant age group attending college, the international scientific and technological competition touched off by the successful Soviet satellite launching in 1958, and the competition among states to provide university centers to facilitate the growth of science-based industry combined to expend university budgets and - because of relative shortage of experienced faculty - to expand salaries and prerequisites (Garbarino, 1973). As a consequence of phenomenal growth, by the $1960 \mathrm{~s}$, the university system emerged with societal influence, as well as economic and political importance (Sherman and Loeffler, 1971). In 1963, W. Clark Kerr, in an address at Harvard University, stated: 
We are just now perceiving that the University's invisible product, knowledge, may be the most powerful single element in our culture, affecting the rise and fall of professionals and even social classes, of regions and even nations (Sherman and Loeffler, 1971).

Therefore, the contemporary American system is best described as a corporate institution or social system (McHugh, 1971; Lipset, 1975). It is a system that has developed into a diverse and complex structure, with no single organizational form (McHugh, 1971). For while some private and public institutions have all their faculty members and staff located on one campus, others are widely separated geographically (McHugh, 1971).

Furthermore, the university system is composed of highly disparate elements (Lipset, 1975). Although most 4-year institutions of higher education have adopted research on the basic value of the academy, its traditional characteristic functions -- research, teaching, and public service are combined to provide for the acquisition, transmission, and application of knowledge in various degrees and for various programs (Lipset, 1975; McHugh, 1971).

\section{Academic Professionalism}

In order for the American system of higher education to meet the expected societal performances as an institution, diverse professionals are appointed to teaching positions within the academy. These appointments bring together the lives and works of the best in each field to form a "community of scholars," (McHugh, 1971) a 
community that through the years has established traditions for the academy--traditions that have formed the academic model of higher education based upon the value and practice of academia.

The academic model of professionalized university teaching embodies three central elements: (1) Research is an important endeavor and the force of the university life, (2) academic work requires peer judgment, and (3) scholarship is a vocation in its own right (Shulman, 1979). The model brought a status that, according to Carol H. Shulman (1979), provides the academician with a new stature. Professional prestige grew as scholars assumed more influence over areas for which they claimed expertise: (1) the academic standards and procedures for undergraduate and graduate education, and (2) terms and conditions for faculty employment. These gains furthered their concept of professionalism by allowing: (1) autonomy in setting standards of performance, and (2) in requesting the terms and conditions of employment (Shulman, 1979).

\section{Academic Governance}

The culture of the academy by the 1960 s further reflected the professionalism of higher education, with the academician role within the university community defined as both a participant and employer. This culture set the standards to which all academicians in general may aspire, that a faculty, in a broad sense of the word, function as a responsible corporate body (Duryea and Fisk, 1973; McHugh, 1971). As James B. Conant, the former president of Harvard University, said: 
This tradition, also developed in the medieval university, prevails in a large measure in the uriversity of today. For in an institution which is a university, in fact as well as name, the teachers are members of a body with vast powers and commensurate responsibilities.... The autonomy of the institute rests fundamentally on the autonomy of each faculty, which embodies in its spirit and action the university tradition (McHugh, 1971).

Therefore, the concept of shared authority became the guiding principle for the development of the academic profession (Duryea and Fisk, 1973). It was a trend that, according to Robert E. Fisk and E. D. Duryea :

Stamped the services of the professionals, making them Inherently more than employees and strengthened the ancient ideal of the university as primarily an association of academicians (Duryea and Fisk, 1973).

In 1966, these principles were concisely articulated for the academy in the "Statement on Governments of Colleges and Universities," which was jointly formulated by the American Association of University Professors, the American Council on Education, and the Association of Governing Boards of Universities and Colleges (Haslam, 1974). This Statement called for a mutual understanding regarding the governance of the academic institutions, stressing shared responsibility and the proper interrelation among the constituencies of administration, faculty, and, to some extent, 
students (Brown, 1969; Haslam, 1974). The appropriate scope of the academician's participation in the academic governance of an institution was defined in the statement as follows:

(a) The faculty has primary responsibility for such fundamental areas as curriculum, subject matter, and methods of instruction, research, faculty status, and those aspects of student life that relate to the educational process.

(b) The faculty sets the requirements for the degrees offered in courses, determines when the requirements have been met, and authorizes the president and board to grant the degrees thus achieved.

(c) Faculty status and related matters are primarily a faculty responsibility; this area includes appointments, re-appointments, decisions not to re-appoint, promotions, the granting of tenure, and dismissal.

(d) The faculty should actively participate in the determination of policies and procedures governing salary increases.

(e) The chairman or head of the department, who serves as the chief representative of his department within an institution, should be selected either by departmental election or by appointment following consultation with members of the department and of related departments; appointments should normally be in conformity with the department members' judgment (Sands, 1971). 
Furthermore, the statement stressed that the principle of shared governance is important to the academy in contemporary times for three major reasons :

(1) The academic institution, public or private, has become less autonomous; buildings, research, and student tuition are supported by funds over which the college or university exercises a diminishing control. Legislative and executive governmental authority, at all levels, plays a part in the making of important decisions in academic policy. If these voices and forces are to be successfully heard and integrated, the academic institution must be in a position to meet them with its own generally unified view, (2) Regard for the welfare of the institution remains important despite the mobility and interchange of scholars, and (3) A college or university in which all the components are aware of the interdependence, of the usefulness of communication among themselves, and of the force of joint action will enjoy increased capacity to solve educational problems (AAUP, $1984)$.

\section{A Conceptive Framework for the}

\section{Traditional Mode of Academic Governances}

The conceptive framework upon which the principles of the traditional modes for academic governances have been developed include these concepts: (1) authority, and (2) power. While these concepts are of ten confused, they can be clearly differentiated. 
The Concept of Authority

Authority is a formal concept and issues from a formal

organization (Hicks, 1967). It is always a property of social

organization with the exercise of authority never extending beyond the limits of the association in which it is institutionalized and which gives it support and sanction (Flippo, 1970). Furthermore, from the use of a basic definition of authority, as a right to act or direct the action of others, two explicit characteristics of authority are stated: (1) authority is a right and (2) as a result of possessing the right, one is entitled and obligated to directly or indirectly act. Also implied but not explicitly stated in the definition is a third characteristic of authority, which involves the power to employ penalties or sanctions so that desired action is completed (Bierstedt, 1964).

The Concept of Power

Power is a broad concept that is not necessarily confined to an organizational contract and that is neither completely formal nor informal in nature, though it may be influenced by subjective factors including ethical and moral considerations (Sisk, 1979; French, 1974).

According to Max Weber: "Power is the probability that one actor within a social relationship will be in a position to carry out his own will despite resistance" (Weber, 1947). Gerald R. Salancik and Jeffrey Pfeffer define power as: "The ability to get things done the way one wants them to be done." (Salancik and Pfeffer, 1977). In 
other words, power is the ability of a person to do something measured in terms of his/her ability to (1) give reward, (2) promise rewards, (3) threaten to withdraw current rewards, (4) withdraw current rewards, (5) threaten punishment, and (6) punish (Hicks, 1967). Power, an emotionally laden term, particularly in organizational cultures that emphasize individuality and equality, is essentially a relationship between people operating as individuals or groups. It does not consist of brute force, coercion, and dominance, but it can be a highly effective instrument in an organization (Flippo, 1970). Although Warren Bennis has stated, "While power is the organization's last dirty secret," power is far from being a dirty business. In its most noted form, power is one of the few mechanisms available for aligning an organization with its own reality. Consequently, power can be viewed, not as a dirty secret, but as a secret to success (Salancik and Pfeffer, 1977).

To demonstrate power as a positive force in an organization Salancik and Pfeffer advance a strategic-contingency model of power theory. This model views power as:

Something that accrues to organizational subunits that cope with critical organizational problems. Power is used by all who have it to: (1) enhance their own survival through control of scarce critical resources, (2) through the placement of allies, i.e., key positions, and (3) through the definition of organizational problems and policies (Salancik and Pfeffer, 1977). Therefore, by the use of the processes to develop and utilize 
power by individuals or groups in an organization, the system becomes more aligned or misaligned with its environment (Salancik and Pfeffer, 1977).

The Concepts of Authority and Power in Academia

In academia, the concepts of authority and power, as implemented within the university system, are best described by three basic contingency models of governance, the (1) collegial, (2) bureaucratic and political.

As shown in Table I, the three models are different in their appearance/process related to governance in the university system in the arena of: (1) image, (2) change, (3) conflict, (4) view of social structure, (5) theoretical foundation, (6) decision-making, and

TABLE I

A Comperison of the Three Basic Coneingency Models of Academic Governsnce (Baldridge, 1971)

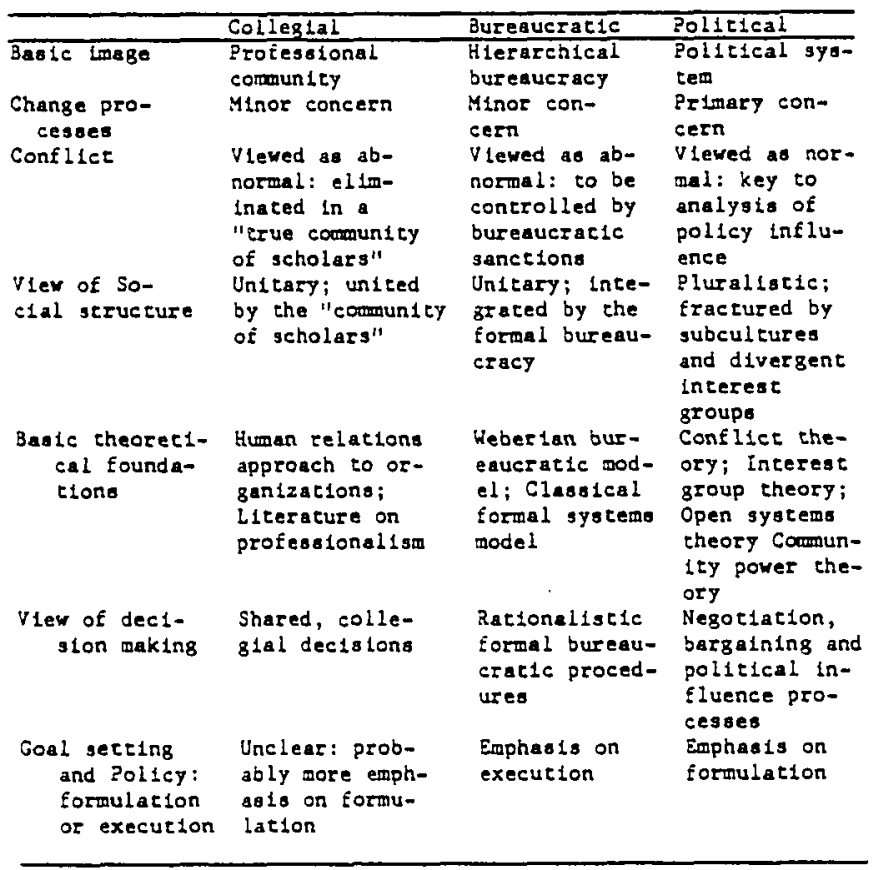


(7) goal setting and policy formulation/execution.

A Supplemental Academic Governance Mode For the University System

For the past two decades, collective bargaining has become a supplemental mode for academic governance in higher education. A complicated force, grounded in a labor movement that dates from the industrial revolution and the twentieth-century organization of workers, the process of academic collective bargaining has, according to E. D. Duryea and Robert S. Fisk (1973):

Posed a significant change in the academic milieu. By 1970 , professionals in an expanded number of institutions had accepted bargaining agents, usually affiliated or associated with a national organization, to represent their interests. In effect, these individuals turned away from a primary dependency on shared governance to a more pragmatic reliance upon the power of organizations outside the disciplinary and professional societies (Duryea and Fisk, 1973).

The process was declared by Irwin H. Polishook (1982) as: "The practice of the decade in higher education, which has grown in greater proportions than the proportion of other Americans who have joined unions" (Polishook, 1982).

\section{A Definition of Collective Bargaining}

The process of collective bargaining, using the basic industrial definition, as written by Marvin J. Levine and Eugene C. Hagburg, (1979), may be defined as:

A joint determination of the terms and conditions of the 
employment relationship by duly chosen employer and employee representatives. The process involves offers and counteroffers, with the ultimate objective of reaching a written contract (Levine and Hagburg, 1979).

Furthermore, the process of academic collective bargaining, which initially was introduced into the university system in 1966 at the United States Merchant Marine Academy, (Garbarino, 1975) has been defined by the following scholars:

(a) William F. McHugh (1971)--Collective bargaining is a process, adversary in nature, which is designed to resolve conflict arising in an employment relationship. The process consists of two fundamental elements: the act of negotiation and the more informal relationship created during the implementation of the contract after it is negotiated and accepted by the parties, 1.e., faculty relations under the contract. This bilateral relationship between faculty and administration characteristically involves problem-oriented consultation between the parties and administration of the contract's grievance system for the purpose of reaching mutual accord. When mutual accord is not achieved, resort may be had to more formal procedures for conflict resolution, such as mediation, fact-finding and arbitration. Thus, collective bargaining, as the term is used here, means not only the actual collective negotiation sessions but also the complicated and subtle university-professional relationships 
that develop as the parties live under the contract (McHugh, 1971).

(b) Donald H. Wollett (1971)--Collective negotiation in the context of higher education, like its counterpart in the private sector, is essentially a process of proposal and counter-proposal, of action and reaction, of give and take--resulting finally in "deal" or "no deal," in agreement or stalemate. The process assumes parity of legal standing between the parties and some bargaining power on both sides. Bilateral determination of the terms and conditions of employment through the process of collective negotiations means that neither party should have the ability to impose its will on the other and that each is able to veto the proposals of the other (Wollett, 1971).

(c) C. Donald Sands (1971)--Collective bargaining can reasonably be viewed as one among alternative procedures for achieving faculty participation in decisions affecting policy at academic institutions. The bargaining process is consistent with historic traditions of relative autonomy for institutions as well as individuals concerning matters of intellect and pays deference to the pragmatic consideration that absent such freedom and independence the academic enterprise cannot effectively serve its historic mission (Sands, 1971).

(d) C. L. Haslam (1974)--Collective bargaining is a process, 
one which lends itself to a variety of expressions. It may indeed lead to an adversary relationship, but it may also result in a kind of enforceable shared authority by virtue of a statutory duty to bargain in good faith. The broad parameters that influence the ultimate impact that collective bargaining has upon institutional relations depend upon the nature of the institution itself, the quality of the issues of local concern, and, above all, the character of the collective bargaining agent (Haslam, 1974).

The Purpose of Collective Bargaining in Academia

The purpose of implementing the process of collective bargaining into the university system as an alternative mode for academic governance, according to Donald H. Wollett, (1971) is twofold:

First, faculty must have the right without legal or other restraints to form and join organizations of their own choosing, to designate their organization and their representatives for the purposes of dealing with their employing institutions, and to participate in related organizational activity. Second, both the faculty organization and the governing board must have the capacity to engage in a process of give and take negotiations (Wollett, 1971).

\section{A Model for Academic Collective Bargaining}

The general labor relations model, as seen in Figure 1 , has been 
adapted to the university system in order to manage activities related to academic collective bargaining.

The model has three major elements: (1) the structure of selecting the bargaining representatives, (2) the structure of negotiating the contract, and ( 3 ) the structure of administering the contract to emphasize decision-making by consensus, rather than to have unilateral decisions imposed upon a faculty by administration (Wollett, 1971). Furthermore, these elements, according to Marvin J. Levine and Eugene C. Hagburg (1979), "have a basic logic and a sequence that is controlled, in part, by established procedure and modified by the behavior of all the participants" (Wollett, 1971).

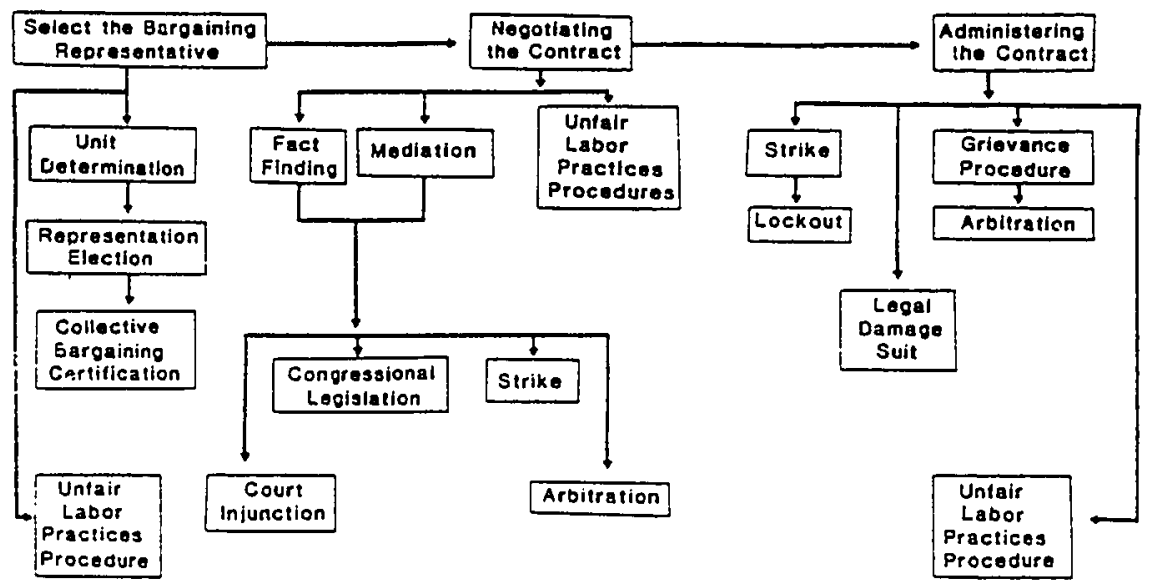

Figure 1. (Levine and Hagburg, 1979) The general labor relations model. 
Patterns of Relationships in Academic

Collective Bargaining

The use of the general labor relations model to implement the process of collective bargaining into the university system is best achieved through the application of the general pattern of labor-management relationships as illustrated in Figure 2.

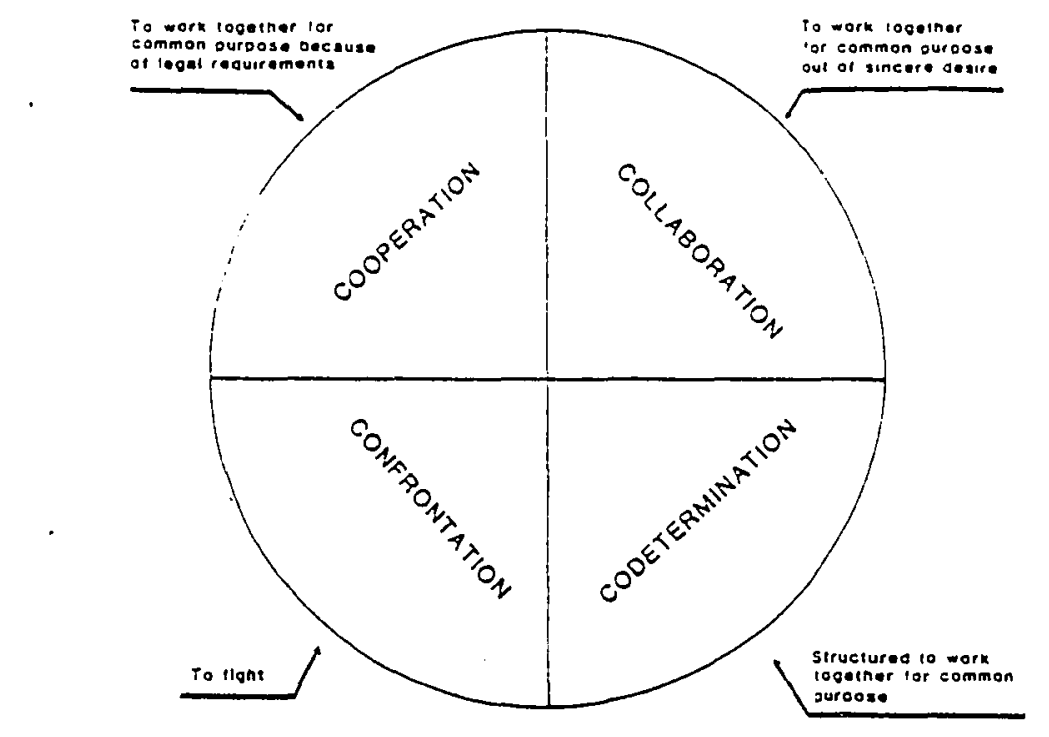

Figure 2. (Levine and Hagburg, 1979) The general pattern of labor-management relationships.

of the identified patterns of possible ways to manage relationships in the academic milieu, two patterns, cooperation and collaboration, are best-suited to prevent or manage conflict in academic governances. First, cooperation is the pattern characterized as working together under law to achieve a common purpose (i.e., the 
labor contract). Second, collaboration is that pattern in which the faculty members and administration consider institutional conflict dysfunctional; therefore, they make a commitment to work together, in order to prevent confrontation in bargaining, to achieve an effectlve organization system in the university system (Levine and Hagburg, 1979).

The Legal Framework For the Establishment of Academic Collective Bargaining

The Federal Sector

Until 1962, federal employees were permitted but a limited right to engage in collective bargaining activities, in part because of the sovereignty doctrine (Levine and Hagburg, 1979). That doctrine held:

The employment relationship in government, like that in the private sector, appears more authoritarian at first than it really is. Government's apparently unlimited authority over its employees was originally based on its sovereignty. The idea that government employees have only the rights that the government permits them is related to the concepts that the king can do no wrong and that government can be sued only with its consent. The sovereignty doctrine has often been used . - to uphold a denial of the right of employee organizations to negotiate the terms of employment (Stanley, 1972).

Furthermore, prior to the enactment of executive order 10988 there was no government-wide system of rights and representatives for 
collective bargaining between federal unions and the employer (Stanley, 1972). As Chairman John W. Macy Jr. of the Civil Service Commission stated in 1962:

The weakest single element in the personnel programs of the $140 \mathrm{~s}$ and the $150 \mathrm{~s}$, in my opinion, was the lack of a realistic and reasonably uniform system of employee-management relations (Macy, 1962).

By 1961 , the federal labor organizations were representing an estimated 760,000 workers on a broad internal scope. These organizations were restricted to the internal utilization of congressional lobbying to improve wages and the working conditions for the federal employees (Macy, 1962). However, these legislative efforts were, according to Marvin J. Levine and Eugene C. Hagburg, "rejected by the executive branch as unnecessary and unduly restraintive of the administrative flexibility required by agency heads" (Macy, 1962).

During the 1960 presidential campaign of John F. Kennedy, the efforts of those involved in the federal sector labor-management relations began to identify a possible change in executive attitude toward the development of collective bargaining on a system of industrial governments when Kennedy stated that: "He had always believed in the right of federal employees to deal collectively with the federal departments and agencies in which they are employed should be protected" (Goldberg, 1962).

Upon his election, President Kennedy appointed a Task Force 
chaired by the Secretary of Labor Arthur J. Goldberg to develop policies related to federal service labor-management relations. By late 1961, the Task Force reported to President Kennedy that a special program needed to be developed to meet the federal sector needs. The Task Force development: (1) recognized the right of federal employees and employee organizations to participate in developing improved personnel policies and working conditions; (2) recommended that employee organizations be consulted and that under specified conditions management be authorized to enter into agreements with unions; (3) called for regularizing arbitration procedures in handling individual employee grievances; (4) requested legislation to authorize voluntary withholding of dues; and (5) recommended the nomination by the Secretary of Labor, when necessary, of panels of expert arbitrators to make advisory recommendations as to what constitutes appropriate units for negotiating purposes and to supervise representation elections (Goldberg, 1962).

On January 17, 1962, President Kennedy issued and signed Executive Order 10988 entitled "Employee-Management Cooperation in the Federal Service" - which established the basic pattern of labor and management relations in the federal sector (Levine and Hagburg, 1979). It introduced three levels of union recognition - informal, formal and exclusive. In addition, the law established the concepts of exclusive bargaining units and regulated agreements in government (Levine and Hagburg, 1979). As shown in Table II, Executive Order 10988 was superseded by 
TABLE II

Stronary of the Major Executive Orders Related to Labor-

Managetrent Relationahtp In Federal Untons and Agency

Management (Levine and Hegburs, 1979)

\begin{tabular}{|c|c|c|c|}
\hline Executive Order & Year Paseed & Presldent & Key Concepts of the Executive Order \\
\hline E.0. 10988 & Jenuery 17.1962 & John $F$. Kennedy & 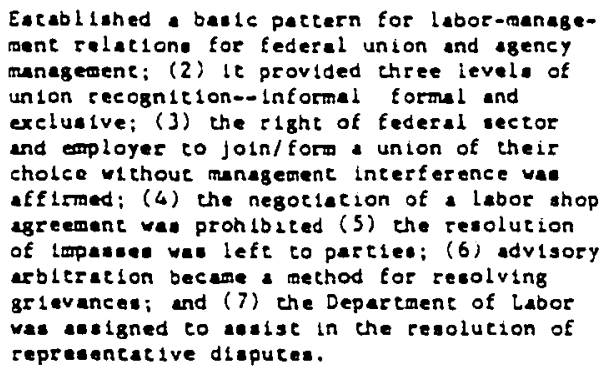 \\
\hline
\end{tabular}

E.0. 11491

October 29, 1969 Richard M. Ntxon

Auguec 26. 1971 Richare 4. NLxon

E.0. 12616

E.0. 11838
Eebruary 6. 1975 Gerald A. Ford
The entabliahment of chree new agencies to centralize decision raking formerly exereised by the individual agencies: Federal Labor Relacions Council to adainister the order. A Federal Service Lapases Panel to aesist the partieo to reoolve negotialing impases. and an asetelant secretary of labor for labormanagemens ralations to determine. number of is suea fomerly decided by the agency head; (2) the Federal Mediation and Concilialion Service was granted a role to mediace negot:ation dispucea; (3) pald tire could be negotialed for union representacives engaged in coneract negotiations up to either a mimum of forty hours or 50 percent of the cotal hours spene in bargaining: ( $A$ ) binding arbitration as the last ecep in the grtevance procedure could be negotiated: (5) the aaminiatrative charge for duan check off could be negotiated; and ( 6 ) the requizement of reporting and discloeure procedurea similar to thone demanded of unions in private erployent vas toposed.

The adminletrative change permltting dues becomea aegotiable item; (2) the negotlated gr levance procedure was now the only one avallable for handilng disputed over the incerpracation and eppilcation of the concraces; and (3) unione can negotiate paid t1de for union zepresentatives engaged in contract negotiations up to either a maximum of ferty hours or so percent of the cotal tian apenc negotiacing.

Facilitated the consolidation of smaller. Inefflctont bargaining untt into ferer iarger onel: (2) broadened the acope of negotiation by limiting the power of national agency regulations to prohibit bargalning tn condicione of oploment; and (3) and the grope of grievence proceduren in contracts a andacory bargaining coptc. 
Order No. 11491 signed into law in 1969 by President Richard M. Nixon (Levine and Hagburg, 1979). This order introduced several significant changes, including the right of federal employees to negotiate binding arbitration as the last step in a grievance procedure (Levine and Hagburg, 1979).

In 1975, President Gerald A. Ford amended Executive Order 11491 with the issuance of E.O. 11838, which required the settlement of disputes arising out of unfair labor practices (Levine and Hagburg, 1979).

\section{The Public Sector}

\section{State Public Labor Laws}

In the United States, the legal endorsement guaranteeing public sector employees the rights to union representation in bargaining was slow to develop. As Joseph W. Garbarino wrote in 1973:

Traditionally, in representing the interests of their members, associations of public employees engaged primarily in lobbying and political activity. They usually limited their membership to a single employing jurisdiction such as a state or county. At times they did include substantial numbers of members from education, but in addition, organizations based upon particular occupational groups were formed to speak for the interest of particular constituencies (Garbarino, 1973). By the late $1960 \mathrm{~s}$, the legal right of public employees to organize for collective bargaining began in the large metropolitan centers of Cincinnati and Philadelphia, with New York establishing a formal system of bargaining by executive order in 1958. The first 
state legislation allowing for collective bargaining by state employees was enacted by the Wisconsin legislature in 1959. This development was further stimulated by President Kennedy's Executive Order 10988, issued in 1962 (Garbarino, 1973). As the president of AFSCME, Jerry Wurf, said in 1966:

His [President Kennedy's] action, which gave federal employees the right to organize and set an example that has been followed by many states, counties, and cities, probably was a major contributing factor in the rapid growth of the American Federation of State, County and Municipal Employees (Wurf, 1966).

The pattern of legislation on public sector collective bargaining that has emerged from the several states is one characterized by a noticeable lack of uniformity in legal requirements and practices. This pattern of diversity is due, in large part, to the absence of any federal standards governing labor relations for state and local government employees, analogous to those set forth in the Wagner Act of 1935 governing labor relations in private sector employment. It might also be argued that the absence of federal legislation on this matter has made it possible for the states to now pre-empt the regulation of labor relations for state and local government employees under a doctrine of States Rights (Levine and Hagburg, 1979). Following this line of reasoning, public sector labor law of the states has tended to be a reflection of the political values and demographic patterns within the various states. As is shown in Table 
III, by 1978 , thirty states had enacted collective bargaining laws that covered all or some categories of public employment, while three states had no laws pertaining to public sector collective bargaining, other states had blanket prohibitions on collective bargaining by public employees.

\section{Collective Bargalning and the University System}

The Entrance of Academic Bargaining

Into the University System

As society developed collective bargaining laws for both the federal and public sector employees, academic unionism emerged as a potent force in higher education (Garbarino, 1973). Joseph W. Garbarino wrote in 1973:

The exclusion to government workers, particularly at the state levels, of the right to organize for collective bargaining is the most signlficant single reason for the present form and growth of academic unions. Furthermore, since education is a function basically of the states, while the degree of encouragement among states varies greatly, permissive state legislation is the key explanation for the burst of academic unions in the late 1960 s and early 1970s (Garbarino, 1973).

Although the legal base for academic unionism was developed, collective bargaining was slow to enter the 4-year institution of higher education. The rationale for this slower growth rate in the university system has been identified by labor relations scholars as 
Table 111

A Summary of the Cheracteriatics of the Hajor

Lawa Enacled In the Public Sector by

1978 (Levine o Hagburg, 1979)

\begin{tabular}{|c|c|c|c|}
\hline Kind of Bargaining Law & Scope of Law & Stated Covered & by Law \\
\hline \multirow[t]{5}{*}{ (1) Comprehenoive Lav } & $\begin{array}{l}\text { Broad-acope collectlue bargalning } \\
\text { on wages, hours and employment } \\
\text { conditions for the stale and local } \\
\text { government employees. }\end{array}$ & $\begin{array}{l}\text { Connect Icut } \\
\text { Howall } \\
\text { Iowa } \\
\text { MaIne } \\
\text { Masaachuaet te } \\
\text { MInneata } \\
\text { Montana } \\
\text { Nebraska }\end{array}$ & $\begin{array}{l}\text { New Hampohire } \\
\text { New Jeroey. } \\
\text { New York } \\
\text { Oregon } \\
\text { Pennoyivania } \\
\text { Rhode Island } \\
\text { South Dakota } \\
\text { Hiscongln }\end{array}$ \\
\hline & $\begin{array}{l}\text { Full-acope bargalning law for local } \\
\text { government employees only. }\end{array}$ & $\begin{array}{l}\text { Mlchigan } \\
\text { Nevada } \\
\text { Oklahoma }\end{array}$ & $\begin{array}{l}\text { Vermont } \\
\text { Hashingt on }\end{array}$ \\
\hline & $\begin{array}{l}\text { Full-acope bargoining laws for } \\
\text { otate omployees. }\end{array}$ & Alaska & \\
\hline & $\begin{array}{l}\text { Limited form of collective } \\
\text { bargaining for otete emplayees. } \\
\text { Thene lawa exclude wage and benefite } \\
\text { from bargeining. }\end{array}$ & $\begin{array}{l}\text { Delaware } \\
\text { Vermont } \\
\text { Haghington }\end{array}$ & \\
\hline & $\begin{array}{l}\text { Law for local governances whose } \\
\text { governing bodieg opt for coverage. }\end{array}$ & Delavare & \\
\hline (2) Heet and Confer Lawe & $\begin{array}{l}\text { A weak law that covers atate and } \\
\text { local employees; it lo limlted to } \\
\text { "meet and confer" requiremente } \\
\text { rather than bargatning. }\end{array}$ & $\begin{array}{l}\text { Callfornia } \\
\text { Florida } \\
\text { Kanasa } \\
\text { Mlaoouri }\end{array}$ & \\
\hline (3) No Law & $\begin{array}{l}\text { No applicable negotlation procedurea } \\
\text { avaliable for elther otate or local } \\
\text { employeea. }\end{array}$ & $\begin{array}{l}\text { Artzona } \\
\text { Colorado } \\
\text { Ohlo }\end{array}$ & \\
\hline
\end{tabular}


threefold:

(1) The elite institutions of higher education have continued to support the concept of the traditional shared governance mode to implement the employment relationships between the faculty and university, (2) in such quality institutions as the Ivy League schools, the prestigious public and private research institutions, and select liberal arts colleges, the professor is perceived as a master, not employee; therefore, an academician does not need a surrogate to plead the "master case" with the university system, and (3) the academy has lived with myths about academic unionism (Hagengruber, 1978; Polishook, 1982). This rationale is further supported by the 1972 study "Professors, Union and Higher Education" conducted by Everett Ladd and Seymour Lipset. The data reported in their study concluded that: Forty-three percent of the faculty sampled agreed that the growth of unionization of college and university faculty is beneficial and should be extended, while 44 percent disagreed, and 13 percent entertained conflicting assessments (Ladd and Lipset, 1973).

The study supported, as shown in (Appendix B), the 1969 Carnegie Commission on Higher Education survey findings that faculty members' selection of bargaining in the university system is based upon two independent sources: (1) class interest, and (2) 1deology. As Ladd and Lipset (1973) stated: 
Professors of low scholarly achievement give greater backing to the principle of collective bargaining than do their most productive colleagues; untenured professors more than those with tenure; and academicians with low salaries are more supportive than their better rewarded associates (Ladd and Lipset, 1972).

Furthermore, the general political views of the academicians are significant factors in the selection of collective bargaining as a supplemental governance mode for the university system. As Ladd and Lipset reported: "Eighty percent of the professors scoring on the liberal-quintile of the Liberalism-Conservative score, concurred that faculty strikes are legitimate means of collective action" (Ladd and Lipset, 1973).

\section{The Scope of Academic Collective Bargaining}

The United States Merchant Marine Academy is reported as the first 4-year institution of higher education to accept collective bargaining. A private school, the Academy was organized in 1966 by the American Federation of Teachers. However, academic unions did not attract public attention until 1969, when the collective bargaining process was introduced into the public university system in the City University of New York. This opportunity was provided for the faculty members of CUNY, as professionals, by the 1967 passage of the Taylor Law in New York State (Garbarino, 1973). It was a law which, according to Donald H. Wollett: "Provided for collective negotiation by state, county and municipal employees, including employees of any 
governmental units operating a public school, college or university" (Wollett, 1971).

Since the initial battle cry, "Professors Unite," in 1969 by Myron Lieberman, a faculty member of CUNY, academic unionism has shown a dramatic growth in the 4-year institutions of higher education (Garbarino, 1973). As shown in Table IV, from the data prepared by The National Center for the Study of Collective Bargaining in Higher Education and the Professions of Baruch College, City University of New York, the major growth years for academic unionism in the 4-year institutions were the mid to late $1970 \mathrm{~s}$, as well as 1981 .

TABLE IV (Douglas, 1984)

GROWTH OF UNIONIZATION IN HIGHER EDUCATION

PUBLIC AND PRIVATE SECTORS, 1974-1983

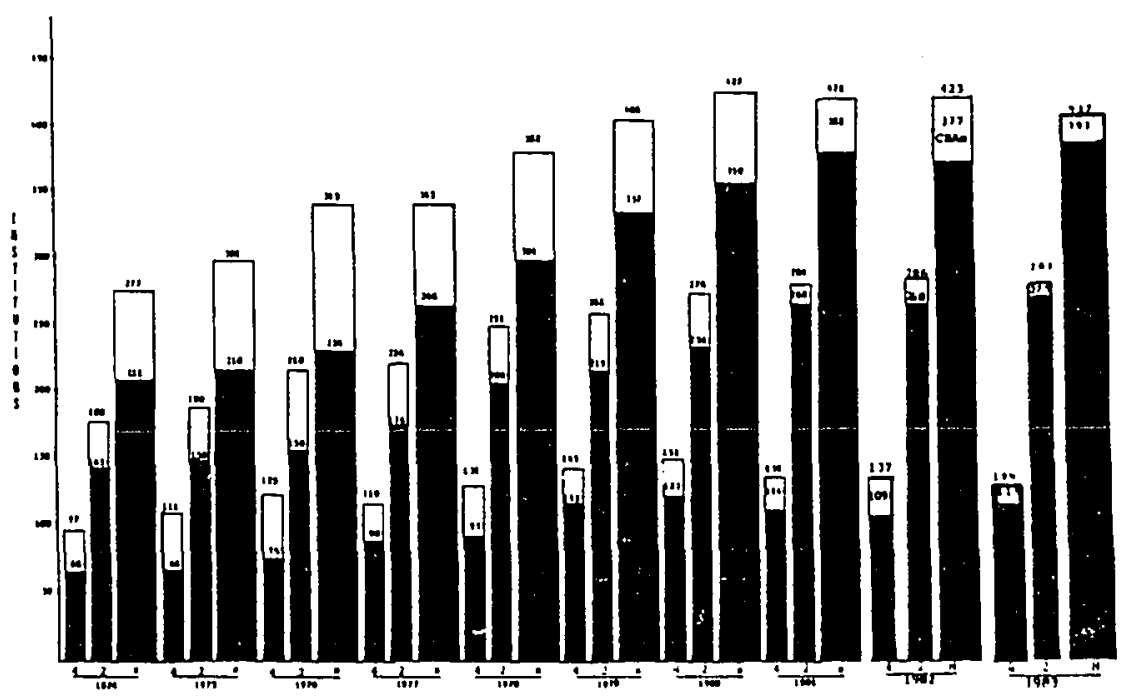

Academic Collective Bargaining Agents and Agreements

In 1984, as shown in Table $V$, there was a total of 134 recognized 
bargaining agents in the 4-year institutions of higher education. of this number, 71 are listed in public institutions, while 63 were reported in private institutions. At the same time, as Table VI demonstrates, 64 agreements were reported in the public institutions and 54 agreements were reported for the private schools.

TABLE V (Douglas, 1984)

RECOGNIZED BARGAINING AGENTS

January, 1984

\begin{tabular}{|c|c|c|c|c|c|c|c|c|c|c|c|c|c|c|c|}
\hline & & renn & enurs & AT & ma & 100 & $\begin{array}{l}\text { navp' } \\
\text { Aft }\end{array}$ & mave' & $\begin{array}{l}\text { Mupl } \\
\text { toso }\end{array}$ & 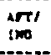 & mear & $\operatorname{arct}$ & Arsoras & 9210 & TOTAL \\
\hline mache & & ; & 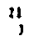 & $\ddot{\prime \prime}$ & 10 & i3 & $!$ & $?$ & : & $?$ & $i$ & 2 & ! & $i$ & $\stackrel{n}{212}$ \\
\hline & TिTAL & & 76 & $\pi$ & $T 2$ & $\pi$ & 2 & 3 & $\bar{\sigma}$ & J & 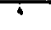 & 2 & 2 & 1 & $-|-| A \mid$ \\
\hline \multirow[t]{2}{*}{ 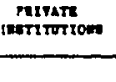 } & & $i$ & $i$ & $!$ & 13 & 1 & : & : & $\vdots$ & $!$ & $\stackrel{0}{0}$ & $:$ & $:$ & $:$ & $\because$ \\
\hline & नTAC & & 8 & 71 & 10 & $\pi$ & 0 & 0 & $T$ & $T$ & 0 & 0 & 0 & 0 & $\pi \cdot 14$ \\
\hline \multirow{3}{*}{$\begin{array}{l}\text { somurt of } \\
\text { trocextizes } \\
\text { netints }\end{array}$} & & 4 & 10 & ut & J3 & 16 & 2 & 2 & 1 & • & 2 & 2 & 1 & - & 134 \\
\hline & & 2 & • & 11 & 169 & 24 & 0 & 1 & 2 & - & 2 & 0 & 1 & 1 & 211 \\
\hline & TTAl & & 6 & 112 & 5012 & $\infty$ & I & $T$ & 1 & 4 & 6 & T & ? & $T$ & min \\
\hline
\end{tabular}

TABLE VI (Douglas, 1984)

ACADEMIC BARGAINING AGREEMENTS

January, 1984

\begin{tabular}{|c|c|c|c|c|c|c|c|c|c|c|c|c|c|c|c|}
\hline & & rean & usur & $\boldsymbol{s}$ & Ner & $1 \times 0$ & Mur' & $\begin{array}{l}\text { suyp' } \\
\text { neA }\end{array}$ & $\sum_{1 \times 0}^{m u p t}$ & tino & Nwo & ACER & wescres & setu & DOTAL \\
\hline Iutritictsons & & $\vdots$ & $\stackrel{29}{1}$ & 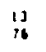 & $\begin{array}{l}11 \\
190\end{array}$ & $3 \frac{3}{12}$ & ? & $i$ & $\stackrel{3}{0}$ & $\vdots$ & $?$ & $a_{0}^{2}$ & $\begin{array}{l}1 \\
1\end{array}$ & $i$ & i64 \\
\hline & DTTAL & & 25 & 99 & is & 3 & 7 & $T$ & 3 & $:$ & 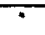 & ? & ? & 1 & -128 \\
\hline intistiontions & & i & 19 & ? & "' & 3 & $\stackrel{0}{0}$ & $\stackrel{8}{0}$ & $\vdots$ & ! & $:$ & o & $:$ & $:$ & ii \\
\hline & 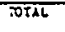 & & 10 & 31 & 16 & 6 & 3 & 2 & $T$ & 1 & 5 & 0 & 3 & 5 & $x=-93$ \\
\hline 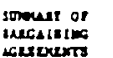 & & • & 19 & $\infty$ & : & ' & : & 2 & : & 3 & 2 & 2 & 1 & 0 & 110 \\
\hline LEstextrots & & $:$ & ${ }^{*}$ & ${ }^{30}$ & ${ }^{103}$ & 13 & 0 & 1 & 0 & ${ }^{\circ}$ & $:$ & 2 & 1 & 1 & 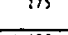 \\
\hline
\end{tabular}


The growth of academic unionism has been attributed to three major national organizations that have actively competed for faculty support in collective bargaining elections (Ladd and Lipset, 1973). These external organizations, the American Federation of Teachers, the National Teachers Association and the American Association of University Professors were identified by William T. McHugh (1971) as: having a more practical appeal because they are better equipped to organize and promote collective bargaining than are local senates or traditional governance organizations because: (1) senates are often comprised of students or employees who do not share a community of interests with faculty in a collective bargaining sense; (2) they have money, trained staff lawyers, and other resources necessary to organize, campaign, and utilize the legal machinery of labor acts; and (3) they are willing to represent the particular cause of an individual faculty member (McHugh, 1971).

While these national organizations share a comnon goal in the university system, the interpretation and implementation of collective bargaining statutes, as Table VII shows, each organization, as an academic union, has a unique profile.

In January 1984, as shown in Table VIII, these three national external organizations continue to represent the majority of faculty members in the 137 4-year unionized institutions. While the AAUP represents 40 institutions of the 134 schools in higher education, the AFT is agent for 31 of the schools and the NEA represents 33 groups. 
The Major National Organizations As Representative

of 4-Year Inotitutiona in Collective Bargaining

Negotlations (Garbarino, 1973; Douglas, 1984)

Organization

The American Federation of Teacher

(AFT)

The National Education

Association

(NEA)

The American Asooctation

of University Professors (AAUP)
Entry Year Into Higher Education Bargaining

\section{Organization Profile}

This organization lo recognized as the ploneer of faculty unionism. It most distinctive feature is the longatanding link with organized labor; it has champloned the trade union model in education. The AFT has been strongest in public 4-year colleges in the industrial otates.

In this organization, the independent members are enrolled into three levela of membership--national. state and local--with the key structure of the organization at the atate level. The NEA atrength in the 4-year college has been almoat entirely in former teacher colleges. particularly in the state of Pennoylvania.

The assoclation developed in 1972 a "Statement on Collective Bargalning" to justify the association Involvement in the collective bargaining process. These justifications are based upon the association's commitment to the fact that:

a. The shaping of collective bargaining should not be left to organizations lacking dedication to principles developed by the Association and widely accepted by the developed by the Aaso

b. The Assoclation is influential in the shaping of collective bargaining, the principles of academic freedom and tenure and the primary reaponalbility of a faculty for determining academic pollcy will be secured.

c. The implementation of Asaciation-supported principles, based upon the profession's traditions and moral auasion can be effectively aupplemented by a collective bargalning agreement and given the force of las. 
While in the public institution, the AAUP is the most common elected bargaining agent, in the private institutions, the AFT is the agent of choice.

Table VIII (Douglas, 1984)

Analysis of Bargaining Agents and Collective

Bargaining Agreements

\begin{tabular}{|c|c|c|c|c|c|c|c|c|c|c|c|c|c|c|}
\hline & the & קטג & sn & res & 100 & writ & $\begin{array}{l}\text { muver } \\
\text { nes }\end{array}$ & nif' & $\underset{1 N o}{N r T}$ & 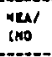 & ares & Asscre & sncus & DCAL \\
\hline 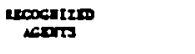 & i & $\bullet$ & נ̈ & 13 & 15 & 3 & 2 & $\begin{array}{l}1 \\
0\end{array}$ & : & 2 & 2 & 1 & $i$ & 134 \\
\hline TOTAL & & 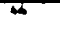 & $\pi 2$ & 202 & 50 & 2 & $J$ & 7 & $\overline{4}$ & 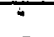 & $\bar{z}$ & 5 & $T$ & $\sqrt{80617}$ \\
\hline 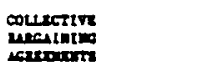 & : & ?9 & $\begin{array}{l}\infty \\
\infty\end{array}$ & $\begin{array}{l}24 \\
163\end{array}$ & i' & 2 & 2 & 1 & $\begin{array}{l}1 \\
0\end{array}$ & 2 & 2 & 1 & $\begin{array}{l}0 \\
1\end{array}$ & $\begin{array}{l}118 \\
275\end{array}$ \\
\hline STRL & & 43 & 310 & 191 & 3 & 3 & 3 & $T$ & 3 & 3 & 3 & $z$ & 7 & $\frac{N=193}{193}$ \\
\hline 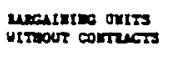 & & 1 & 2 & 14 & 9 & 0 & 0 & 0 & 1 & 0 & 0 & 0 & 0 & $9=26$ \\
\hline
\end{tabular}

The Subject of Contract Negotiations

in Academic Bargaining

The formal collective bargaining procedure as accepted in the university system of higher education is a process intended to contractually attain participation in academic governance. As William F. McHugh (1971) wrote,

Academic Collective Bargaining is a formal procedure which insures appropriate consultation and opportunity for the professional staff to present ideas and attitudes to the governing boards or other sources of authority are appearing in contracts (McHugh, 1971). 
However, the negotiation of a contractural agreement in the academy requires that established labor laws be adjusted to the unique university governance structure (Schwartzman, 1974). Furthermore, in academic collective bargaining, where the application of these principles presents unique problems, (Glidden, 1977) the contract according to Herbert $D$. Schwartzman, must:

Determine not only the relative rights, duties and obligations of the contracting parties, but also the effect of the collective bargaining relationship upon the governance structure of the university. Conversely, where such matters as appointment, promotion, tenure, discharge, etc., are subject to peer judgment, the collective bargaining agreement should not provide a means of obviating, by arbitration or otherwise, an adverse decision by the peers or the reviewing bodies in the governance structure (Schwartzman, 1974).

For the faculty member with an appointment in the academy, the "terms and conditions" of employment have been defined to include the traditional issue of collective bargaining, as well as a wider spectrum of subjects than are usually found in public employee contracts (McHugh, 1971). The scope of these subjects is rooted in the concept of shared authority a concept, according to William F. McHugh (1971), that:

Faculty should share in the governance of the institution. Thus, the concept of negotiable issues covers everything from admission, class size, academic calendar, procedures for 
budget formulation, participation in physical plant planning and expansion, allocation of resources, to athletic policy and procedures for selection of administrators and department chairmen. This concept of "shared authority," peculiar to educational institutions, includes a wider spectrum of matters than customarily associated with industry or public employment bargaining (McHugh, 1971).

The right of the academician to a wider spectrum of bargaining subjects in the university system was fully supported by the American Association of University Professors' "Statement on Government of Colleges and Universities" as formulated in 1966 in collaboration with the American Council on Education and the Association of Governing Boards of Universities and Colleges. This "Statement" called for a mutual understanding regarding the governance of an institution, stressing the principles of shared governance as significant to the academy in contemporary times (AAUP, 1984). This position justified faculty responsibilities to participate in academic governance because:

Faculty judgment is central to general educational policy. Furthermore, scholars in a particular field or activity have the chief competence for judging the work of their colleagues, in such competence it is implicit that responsibility exists for both adverse and favorable judgment. Likewise there is the more general component of experience, faculty personnel committees having a broader charge (Sands, 1971). 
Furthermore, the American Association of University Professors' 1969 "Statement of Policy on Representation of Economic and Professional Interests," detailed that:

Through the negotiation of a collective agreement it may in some institutions be possible to create a proper environment for faculty and administration to carry out their respective functions and to provide for the eventual establishment of necessary instruments of shared authority and responsibility in purely educational, curricular and legislative matters (Sands, 1971).

In 1971 , Donald H. Wollett further characterized issues related to academic contract negotiation into four major categories of faculty concerns, during an address to the National Conference of Collective Negotiation in New York. As shown in Table IX, the five major categories of issues presented were: (1) procedures for faculty representation; (2) educational policies; (3) working conditions and the administration of personnel policies; (4) aggregate economic issues; and (5) public issues and the institution. 
TABLE IX

The Specific Issues Relative to the Five

Major Categorles of Academic Contract

Negotiations (Wollett, 1971)

Five Major Categorles

1. Procedure for Faculty Representation

2. Educat Ional Policy

Working Conditions Personel Polictes

4. Aggregate Economic Issue

5. Publfc Issues and the Ingtitute
Specif Ic Issues of the Category

The right to participate in the formulation of the organic law that defines the nature of their representation with the institution.

These issues include: academic standarda, curriculum, degree requirements, grading standards, standards of academic freedom, standards for student conduct and discipline, procedures for the appointment of administrative personnel.

These issues include: appointment, promotion, tenure, course asslgnments, work schedules, work load, salaries and fringe benefits, of ice space, secretaries, service and grievance procedures.

These issues include: the allocation of resources to major budgetary categories, salarles and fringe benefits and the allocation of funds to support the major educational objectives of the institution.

The right to participate in the formation of institutional policles related to public questions that have a direct and important effect on the operacion of the ingriturtion. 


\section{Collective Bargaining in the Oregon System of}

\section{Higher Education: Focus on the 4-Year Institutions}

In 1973, Oregon enacted significant comprehensive bargaining laws for the educator as a public employee. These laws permitted faculty members with an appointment in an Oregon 4-year institution of higher education to select collective bargaining as a supplemental governance mode for their participation in institutional governances (Garbarino, $1973)$.

Since 1973, three of Oregon's eight 4-year institutions of higher education have entered into collective bargaiing. The initial contract was implemented in 1975 at Southern Oregon State College. In 1979, additional academic collective bargaining contracts were implemented for faculty members at Western Oregon State College and Portland State University (Douglas, 1984).

Faculty members at Southern Oregon State College are represented by an independent agent, while the American Federation of Teachers was chosen to represent Western Oregon State College and the American Association of University Professors was elected as the bargaining agent for Portland State University.

In addition, five "no-agent" faculty elections have been reported between 1975 and 1983 at other 4-year institutions of higher education in Oregon. Coalitions were defeated in 1975 at Oregon Institute of Technology and during 1977 at the University of Oregon, Eastern Oregon State College and Oregon State University. A second loss for a collective bargaining election was reported in 1983 at Oregon State College (Douglas, 1984). 
The Effects of Academic Collective Bargaining

in the University System

Since 1966, acceptance of academic collective bargaining as a supplemental governance mode has grown in the university system of higher education. As Jack L. Nelson, a Rutger's University professor, wrote in 1982: "The past two decades have seen a dramatic increase in the number of states, institutions, and individual faculty members operating under collective bargaining agreements" (Nelson, 1982). Therefore, the myths that initially challenged the acceptance of collective bargaining by the academy have, according to Irwin $H$. Polishook:

Given way to mature relationships based upon the acceptance of collective bargaining by the administration and a mutual commitment to use the process to protect the integrity of the university (Polishook, 1982).

The research of Begin, (1974) Kemerer and Baldridge, (1976) Mortimer, et al. (1976) and Lee, (1979) as well as the scholarly contributions of Nelson (1982) and Polishook (1982) further support the selection of collective bargaining by faculty members as a positive supplemental governance mode for the university system. Their studies have documented that while collective bargaining is a form of adversarial governance, it has not fostered disharmony in the university system. Furthermore, academic collective bargaining has established faculty unions and faculty governance bodies as partners in a reciprocal process that has supported, clarified, and enhanced 
institutional governance structure, in order to guarantee or advance faculty rights. As Jack L. Nelson wrote in 1982:

While there were some initial problems, collective bargaining actually clarified the decision-making process and a number of previously ambiguous topics in academia. Collective bargaining is one of the few ways to bring some semblance of balance into academic decision-making (Nelson, 1982). In 1979, the study of Barbara A. Lee further identified the position of academic collective bargaining as a positive force on governance structures in the university system. Eight major conclusions confirmed that:

(1) Faculty as a whole gained formal governance power through the union contract. Even on campuses where faculty had enjoyed considerable decision-making power, the contract legitimated and in many cases broadened the scope of the faculty's governance role.

(2) Administrators at the vice presidential level and presidential level acquired greater authority over formal decisions, particularly in personnel matters, many of which had once been made by deans and "rubber-stamped" by administrators at higher levels. Contracts now stipulated decision responsibility and accountability at levels above the dean.

(3) Deans appeared to have lost much of their autonomy over personnel and workload decisions; however, they retained much 
of their authority to allocate budgets.

(4) The single most significant effect of unionization at the six institutions visited was the promulgation of a formal grievance procedure. This process resulted in promotion and tenure policies generally considered to be fairer and more consistent than practices prior to unionization.

(5) At institutions where senates were relatively new or had minimal faculty support, senates were abolished and replaced with union-dominated faculty comittees. At institutions with traditionally strong faculty senates, unions respected senate prerogatives and focused on economic issues. At these latter institutions, senate and union leadership overlapped.

(6) On campuses that had a tradition of faculty participation in governance, union influence appeared minimal. However, it was evident that external threats against faculty autonomy or a reversal of the administration's cooperative attitude would energize and strengthen the union.

(7) Unionization tended to formalize relationships between faculty and administration, regardless of the quality of these relationships. This formalization reduced the ability of an individual to influence decision-making by informal means. (8) Departments, as academic units, either retained their former decision-making power or gained additional power as a result of unionization. Nearly all academic and most personnel decisions were made at this level and usually 
prevailed (unless prevented by budget restrictions). Because the grievance process usually started with the chairperson or the dean, departmental decisions seldom were challenged except on due process grounds (Lee, 1979).

The forthcoming study of Kemerer and Baldridge will identify four positive trends that have occurred in the university system as a result of academic collective bargaining. The trends, as reported in 1980 by J. Victor Baldridge support that:

(1) The collective bargaining process standardized procedures in personnel practices for the academicians, with the benefits to them identified as: (a) order to the system, and (2) increased equity.

(2) The collective bargaining process helped the economic status of the profession. The bargaining process seems to have generated additional money.

(3) The collective bargaining process resulted in the so-called "dual track" relationship between faculty senates and unions, whereby senates serve faculty members' academic interests and unions serve their economic concerns, remaining viable at campuses that have both unions and senates. (4) The collective bargaining process may be an incentive to the "decentralization" of administrative powers and authority (Baldridge, 1982).

Twenty years of empirical study by the academy has disproved the initial myths and concerns about the adoption of collective bargaining 
in the university system; therefore, in 1983, according to Irwin $H$. Polishook:

The real "adversary" within the academic community is the Individual who continues to perpetuate a mythology of faculty unions without coming to grips with the practice of a decade (Polishook, 1982). 


\section{Chapter III \\ RESEARCH METHODOLOGY AND PROCEDURE}

Introduction

This chapter presents the research methodology and procedures selected for the conduct of this evaluative research survey. The presentation will include a review of the (1) research model, (2) research methodology, and (3) procedures specific to the study, which includes a discussion of the (a) research instrument, (b) population, (c) data collection, and (d) the data analysis. selected for the study.

The Research Mode 1: Synthesis of Theory and Fact

\section{Introduction}

The research model for this study was developed from the comprehensive literature review as presented in Chapter II. Scholarly contributions and research studies, which cite academic collective bargaining as a supplemental governance mode adapted in the university system to support faculty members' participation in institutional governance, were used to design the theoretical framework for this research study. Specifically, the literature supports:

(A) A relationship between the faculty members' demographic profile (professional status and academic appointment) and their endorsements of academic collective bargaining (Ladd 
and Lipset, 1973; Garbarino and Aussieker, 1975; Wollett, 1971).

(B) A relationship between the influence of contextual factors on a university system's structures/function and the decision of a faculty to select academic collective bargaining as a supplemental mode in lieu of the traditional forms of institutional governance (Begin, 1978; Kemerer and Baldridge, 1975; Mortimer and Richardson, 1977; Lee, 1979).

(C) The relationship of academic collective bargaining as a supplemental governance mode for the university system and the support that the process should provide for faculty members to participate in decision-making issues related to institutional governance (Baldridge, 1982; Hedgepeth, 1974; Lee, 1979; Nelson, 1982; Polishook, 1982).

The design for the research model, as shown in $F$ igure 3, was based upon three fundamental assumptions regarding the adoption of academic collective bargaining as a supplemental institutional governance mode in a university system. These assumptions include (1) demographic factors, (2) contextual factors, and (3) those issues related to a faculty member's professional rights to participate in institutional governance.

\section{Demographic Factors}

This section of the study was developed to assess the demographic factors (professional status and academic appointments) of those 


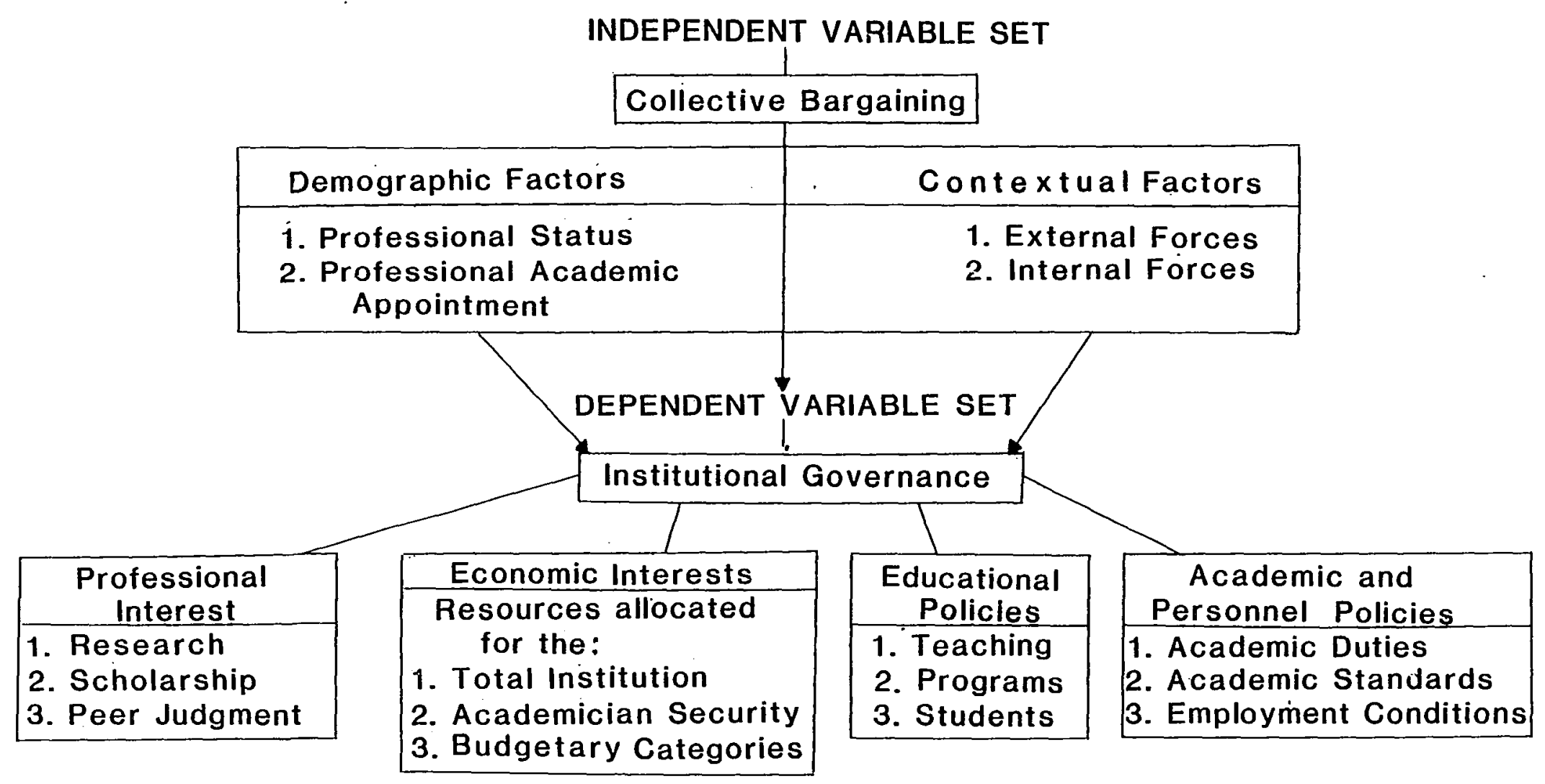

Figure 3. A schematic diagram of the theoretical research model 
academicians who have endorsed academic unionism for one of Oregon's 4-year institutions of higher education.

In the university system, there are two major sets of demographic factors: (1) class interest, and (2) political orientation, which can be used to profile those academicians who tend to support academic collective bargaining.

Most faculty members who select academic collective bargaining as a supplemental governance mode hold an appointment in a 4-year institution identified with a lower scholarly prestige, fewer financial resources and economic benefits. Furthermore, these academicians usually hold a lower academic rank, lack tenure, are younger and perceive themselves as liberal in political issues/attitudes (Ladd and Lipset, 1973).

For this study, the following demographic factors were included in the research design:

1. The academic department/school.

2. Academic rank.

3. The number of years of teaching in a 4-year institution.

4. AAUP membership.

5. Salary.

6. Appointment to a university/department academic governing committee.

7. Age range.

8. The amount of involvement with the collective bargaining process. 


\section{Contextual Factors}

For this section of the study, the research model was designed to identify the contextual factors, either external or internal to the university system of employment, which influenced faculty members to select academic bargaining as a supplemental governance mode.

Contextual factors are forces, either external or internal to a university system, which have the potential to influence both structural and functional changes within a system. Consequently, these changes can directly impact the governance structures of the institution, which includes: (1) the locus of decision-making, (2) the amount of bureaucratic regulations, and (3) the degree of faculty autonomy within an institution (Lee, 1979).

Two specific sets of issues related to: (1) external factors and (2) internal forces, which have the potential to impact the structure and function of a university system, were developed in the research model for this segment of the study.

\section{Institutional Governance}

Academic institutional governance is a process that refers to the formal structure and activities used in a university system to make those decisions that affect relationships, procedures, and policies (Duryea and Fisk, 1973).

As shown in Figure 4, the concept of academic institutional governance is used to form the dependent variable set of the research model. For this study, the dependent variable set is divided into four specific subsets related to governance issues: (1) professional 
interests, (2) economic interests, (3) educational policies, and

(4) academic and personnel policies.

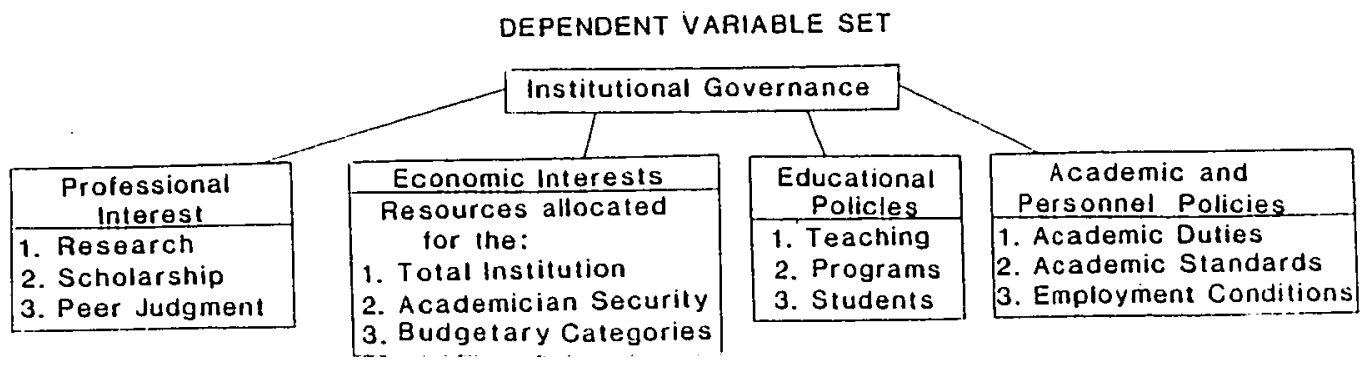

Figure 4. The dependent variable set of the research model

\section{Professional Interests}

This dependent variable subset of the research model was designed to evaluate the impact of the academic collective bargaining process as adopted in three of Oregon's 4-year institutions of higher education, on the professional status of university teaching.

Since the 1960s, shared authority has become an accepted form for academic governance for faculty members and administrators in the university system. Shared governance stamped with professional status the services of the professoriate, thereby making their role more than that of employees and strengthened the ancient idea of the university as primarily an association of scholars. Furthermore, the concept of shared authority became the guiding principle for the development of the academic profession, with research and scholarly contribution as the major criteria for evaluating the academician's achievement (Duryea and Fisk, 1973). 
In 1966, the academy introduced collective bargaining as a supplemental governance mode for the university system. This process has accentuated the organizational role of the academician as an employee in contrast to the ideal of a professional who is a participant in the academic enterprise (Duryea and Fisk, 1973). Specific professional interests of the academician included in this dependent variable subset are (1) research, (2) scholarship, and (3) peer judgment.

\section{Economic Interests}

This subsection of the dependent variable set was designed to investigate faculty members' participation in the decision-making process of those academic governance issues related to economic interests.

Before 1972, the watershed years of academic growth provided the academy, as well as the academicians, with "economy gains" in salaries, student enrollment, and research funding. However, this past decade has shown a steady decline in academic compensation and student enrollment, as well as less federal and state funding available to the university system. Consequently, the American professoriate, while wanting to retain the academy's traditional belief that the academicians' salary is not a wage, has decided to accept academic unionism to protect its economic interests (Krueger, 1979). It is a decision that the American Association of University Professors recognized as significant and defined in the 1969 
"Statement Policy on Representation of Economic and Professional Interests" by stating:

Collective bargaining may play a significant role in bringing agreements between faculty and administration on economic issues (AAUP, 1984).

The scope of faculty members' participation in the governance of the institution's economic issues should include involvement in short-range as well as long-term planning regarding budgetary decisions for the institution (Mason, 1982). As Henry J. Mason (1982) states:

In the budgetary process, while faculty must keep itself available to give advice day to day, it should also seek involvements in the planning process. Otherwise, it faces the real danger of lost initiative, in which budgets drive and control academic plans and programs, rather than the reverse (Mason, 1982).

For the study, three aggregate economic issues related to faculty members' rights to participate in the total financial process of the institution were included: (1) the total resources available to the institution, (2) the distribution of resources allocated to provide for the academicians' economic security, and (3) the allocation of resources to major budgetary categories.

\section{Educational Policies}

This particular dependent variable subset was developed to 
measure faculty members' participation in those academic issues of institutional governance related to educational policies.

In the academic community, tradition has established the right of faculty members to be active participants in determining educational policies for a university (Sands, 1971). Furthermore, faculty members have the primary responsibility to establish those policies and procedures that govern the educational process because their judgment as educators is central to general educational policy (AAUP, 1984).

In addition, faculty members have the right and responsibility for the establishment of those policies and procedures specific to: admission standards, curriculum, teaching method, degree requirements, grading standards, types of degrees offered, the establishment of programs, as well as those issues related to student life, which includes conduct and discipline.

For the study, three areas of educational policies were included in the research model. These areas studied those policies in a university system related to (1) teaching, (2) programs, and (3) students.

Academic and Personnel Policies

This subsection of the dependent variable set was selected for inclusion in the study to evaluate the faculty members' participation in governance issues related to personnel policies and the working conditions of their institution.

University educators have the primary governance authority for 
all matters related to faculty status (Sands, 1971). As the 1969 "Statement on Governance of Colleges and Universities" of the American Association of University Professors states:

Scholars in a particular field or activity have the chief competence for judging the work of their colleagues; in such competence it is implicit that responsibility exists for both adverse and favorable judgments (AAUP, 1984). Among the factors that relate to the faculty status of the university educator in the area of personnel policies are: appointments, promotion, tenure, salary, and teaching schedule. In addition, the academician has a right to participate in decisions related to the working conditions of his employment, which includes the issues of office space or secretarial or support office services (Wollett, 1971).

Three major areas related to the personnel policies and the working conditions of unionized faculty members were used in this section of the study: (1) academic duties, (2) academic standards, and (3) employment conditions.

\section{The Research Methodology}

\section{An Evaluative Survey}

The purpose of this evaluative research survey was to study select faculty members with an academic appointment in Oregon's 4-year unionized institutions of higher education to determine whether or not collective bargaining has supported faculty members' rights for 
participation in institutional governance. To achieve the stated purpose, the following problems were investigated:

1. Have the professional interests of the academician with an appointment in Oregon's 4-year institutions of higher education been affirmed through the collective bargaining process?

2. Has collective bargaining provided for the academician's participation in financial planning and policy-making related to the economic interests as an employee in Oregon's 4-year institutions of higher education?

3. Do faculty members with an academic appointment in Oregon's 4-year unionized institutions of higher education participate In determining the educational policies for the institution that are related to academic issues?

4. Has the collective bargaining process provided support for the faculty members in Oregon's 4-year institutions of higher education rights to participate in determining the academic and personnel policies of their employment?

The research methodology for this study was reviewed for compliance with the DHEW policies and regulations for the protection of human subjects by the Human Subjects Research Review Committee of Portland State University. The methodology was approved by the committee, as providing adequate provisions to protect the rights and welfare of the human subjects (See Appendix C). 


\section{Procedures for the Study}

The Research Instrument

The research instrument, "A Questionnaire to Study Collective Bargaining As A Process Adopted In Oregon's 4-Year Institutions of Higher Education to Provide for Faculty Members' Participation in Institutional Governance" was designed for this evaluative survey to include three parts: (1) Respondent Information, (2) Institutional Information, and (3) Institutional Governance Information.

a. Part I - Respondent Information of the questionnaire was designed to collect demographic information about the faculty members with an appointment in Oregon's three 4-year unionized institutions of higher education. The information, which includes personal and professional characteristics, was used to identify a professional profile of the faculty members as an aggregate group and as employees of the three unionized institutions.

The six specific demographic factors included in this research design are: (1) the number of years of teaching in a 4-year institution, (2) AAUP membership, (3) salary, (4) appointment to a university/department, (5) age range, and (6) institutional involvement with the collective bargaining process. (See Questionnaire items: 1, 2, 3, 4, 5, 6.) 
b. Part II - Institutional Information of the research instrument was a section designed to identify those contextual factors, both external and internal to the university system, which influenced the faculty members with an appointment in Oregon's three unionized 4-year institutions of higher education to vote for a new bargaining contract in 1983.

For the research design, those questions related to the contextual factors were: (1) student enrollment, (2) state and federal funding, (3) institutional growth, (4) a decline in academic programs, (5) decentralized policy-making, student power, and (6) the effectiveness of the university's academic senate/council, organizational structural change. (See Questionnaire items: 7, 8, 9, 10, 11, 12, 13, 14, 15, $16,17,18,19$.

c. Part III - Institutional Governance Information - items were 36 statements developed to collect data specific to the dependent variables set of the research model, institutional governance. Four dependent variable subsets:

(1) professional status, (2) aggregate economic issues, (3) educational policies, and (4) working conditions/personnel policies were used to study select faculty members with an appointment in Oregon's 4-year institutions of higher education in order to evaluate academic collective bargaining as a supplemental governance mode in higher education to: 
1. Affirm the professional status of the academician in Oregon's 4-year institutions of higher education (See Questionnaire items: $20,21,22,23,24,25,26,27$.

2. Provide for the academic participation in the financial planning and policy-making related to the aggregate economic factors of Oregon's 4-year institutions of higher education. (See Questionnaire items: $28,29,30$, $31,32,33,34,35,36$.

3. Provide for the academicians' participation in determining the institution's educational policies related to academic issues (See Questionnaire items: 37 , $38,39,40,41,42,43)$.

4. Provide for the academicians' participation in determining the conditions of employment and personnel policies (See Questionnaire items: $44,45,46,47,48$, $49,50,51,52,53,54,55,56$.

A Likert five-point scale: (5) strongly agree, (4) agree, (3) undecided, (2) disagree, or (1) strongly disagree was used to measure the responses to each item of the questionnaire, except in Part III, D. Working Conditions. For this section, a 4-point scale of: (4) always, (3) frequently, (2) infrequently, and (1) never was used to evaluate collective bargaining as a supplemental governance mode to provide support for faculty members' right to participate in determining those policies related to: (1) Academic Duties, (2) Academic Standards/ Personnel Policies, and (3) Support Services. 
The research instrument was designed and developed between January 1983 and May 1984, under the direction of Dr. Walter Ellis, Chairperson of the investigator's Dissertation Committee. Special assistance with the final revision of the instrument was provided by Dr. Gary Johnson, a statistician; Dr. Mark Starr, a research methodologist; Dr. George Guy, Professor of Education; Dr. Daniel O'Toole, Associate Professor of Public Administration; and Dr. Ken Kemper, Assistant Professor of Education.

The Research Population

The population selected for this research study, as shown in Table X, was 694 faculty members with an academic appointment in one of Oregon's three unionized 4-year institutions of higher education, spring 1984. Each subject of the identified population met the following three criteria, as each: (1) held a full-time faculty appointment during the 1983-84 academic year, (2) had been employed by the institution a minimum of five years, and (3) had tenure or was on a tenure track appointment in the school/department of the university.

The population for this study was identified from the data base used for November 8, 1983, payroll tapes and the EEO-6 report Fall 1983 for the subject institution. This data was provided the researcher by Ms. Mary E. Ricks, Research Assistant, of the Office for Institutional Research at Portland State University (See Appendix D). Although all respondents nominally met the three requirements above, 
TABLE $X$

Distribution of the Identified Population for the Research Study in Oregon's Three Unionized 4-Year Institutions of Higher Education

\begin{tabular}{lcc}
\hline $\begin{array}{l}\text { Four Year Unionized } \\
\text { Institution }\end{array}$ & $\begin{array}{l}\text { Number in } \\
\text { Population }\end{array}$ & $\begin{array}{l}\text { Percentage of the } \\
\text { Total Population }\end{array}$ \\
\hline $\begin{array}{l}\text { Western Oregon State } \\
\text { College }\end{array}$ & 129 & $(18.6 \%)$ \\
$\begin{array}{l}\text { Southern Oregon State } \\
\text { College }\end{array}$ & 148 & $(21.3 \%)$ \\
$\begin{array}{l}\text { Portland State } \\
\text { University }\end{array}$ & 417 & $(60.1 \%)$ \\
Total & 694 & $(100.0 \%)$ \\
\hline
\end{tabular}

one respondent nevertheless indicated less than 5 years of teaching.

In order to secure permission to request the use of the data base, the legal ramifications for requesting access to the data were discussed with Mr. Michael A. Corn, Assistant to the President for Legal Affairs, Portland State University. Therefore, permission to secure and use the data base to identify the population for the study was given to the investigator through the office of $\mathrm{Dr}$. Margaret $\mathrm{J}$. Dobson, Vice President, Academic Affairs, Portland State University; Dr. James H. Beaird, Provost, Western Oregon State College in Monmouth, Oregon; and Dr. Ernest E. Ettlich, Dean of Academic Affairs, Southern Oregon State College in Ashland, Oregon (See Appendix E).

\section{The Data Collection}

On May 21, 1984, the research instrument "A Questionnaire to 
Study Collective Bargaining As a Process in Oregon's 4-Year

Institutions of Higher Education to Advance Faculty Members' Rights For Participation in Institutional Governance" was mailed to the 694 subjects identified for this research study. The questionnaire was accompanied by a letter and self-stamped envelope for returning the completed questionnaire to the investigator (See Appendix F).

A follow-up post card was mailed to the subjects on May 28, 1984, with a second appeal letter, accompanied by a questionnaire and self-stamped envelope, mailed on June 4, 1984, to all non-respondents, as of that date (See Appendix G).

Questionnaires were returned to the investigator from 523 or $75.4 \%$ of the population selected as subjects for the study between May 23, 1984, and August 10, 1984. As shown in Table XI, 277 or $51.0 \%$ of the questionnaires were returned from wave one, 100 or $20.6 \%$ were returned following the second wave, while 109 or $22.4 \%$ of the respondent questionnaires were returned following the third wave.

From the 523 questionnaires returned, 486 or $92.9 \%$ were accepted as data-producing and used in the analysis process of the study. However, in the presentation and analysis of the data, faculty responses to each category of the research instrument may not total 486, because the academicians did not always respond to each item of the instrument.

Thirty-seven or $7.1 \%$ of the returned questionnaires were rejected for use in the study because of: (1) incomplete data, (2) the educator, while retaining faculty rank and tenure in the subject Institution, now holds an administrative position, and ( 3 ) the 
TABLE XI

\begin{tabular}{|c|c|c|c|c|}
\hline \multirow[b]{2}{*}{ Inet1 tut 1 on } & \multicolumn{4}{|c|}{$\begin{array}{l}\text { Number of Data-Producing Responses } \\
\text { Recefved W1th Each Wave/Request }\end{array}$} \\
\hline & $\begin{array}{l}\text { Flrst Wave } \\
\text { May } 22-30 \text {, } \\
1984 \\
N \quad(z)\end{array}$ & 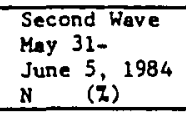 & $\begin{array}{l}\text { Third Wave } \\
\text { June } 6-\text { August } \\
10,1984 \\
\mathrm{H}(7)\end{array}$ & Total \\
\hline $\begin{array}{l}\text { Weatern Oregon State } \\
\text { College }\end{array}$ & $45(56.3)$ & $18(22.5)$ & $17(21.3)$ & 80 \\
\hline $\begin{array}{l}\text { Southern Oregon State } \\
\text { College }\end{array}$ & $47(47.0)$ & $30(30.0)$ & $23(23.0)$ & 100 \\
\hline $\begin{array}{c}\text { Portland State } \\
\text { University }\end{array}$ & $185(60.5)$ & $52(17.0)$ & $69(22.5)$ & 306 \\
\hline Total & $277(57.0)$ & $100(20.6)$ & $109(22.4)$ & 486 \\
\hline
\end{tabular}

questionnaire was received after August 10, 1984.

While 523 faculty members returned the received instruments to the investigator, 171 chose to not participate in the study and did not return the questionnaire. From the total data available, the non-respondents can be profiled, as shown in Table XXII, according to:

(1) employing institution, (2) academic area of appointment, and

(3) academic rank.

Following the selection of usable questionnaires for the study, the questions were coded and a "Respondent Codebook - Collective

Bargaining as a Process Adopted in Oregon's 4-Year Institutions of Higher Education to Support Faculty Members' Participation in Institutional Governance" was written for key-punching the data for computer analysis (See Appendix H). Missing responses were recorded as a 9 . 
TABLE XII

\begin{tabular}{|c|c|c|c|c|c|}
\hline & \multicolumn{2}{|c|}{ Wonzespondents } & \multicolumn{2}{|c|}{ Respondencs } & \multirow[t]{2}{*}{ Tocal } \\
\hline & s & $(\pi)$ & s & $(\%)$ & \\
\hline \multicolumn{6}{|l|}{ Employtng institurion } \\
\hline $\begin{array}{l}\text { DOSC } \\
\text { SOSC } \\
\text { PSU }\end{array}$ & $\begin{array}{l}42 \\
31 \\
98\end{array}$ & $\begin{array}{l}(34.4) \\
(23.7) \\
(24.3)\end{array}$ & $\begin{array}{r}30 \\
100 \\
306\end{array}$ & $\begin{array}{l}(65.5) \\
(76.3) \\
(75.7)\end{array}$ & $\begin{array}{l}122 \\
131 \\
504\end{array}$ \\
\hline Tor21 & 171 & $(26.0\rangle$ & 486 & $(74.0)$ & 557 \\
\hline \multicolumn{6}{|l|}{ Jepartmenc" } \\
\hline $\begin{array}{l}\text { Liberal areg/ares of Sct. } \\
\text { Professional } \\
\text { Other }\end{array}$ & $\begin{array}{r}110 \\
52 \\
9\end{array}$ & $\begin{array}{l}(27.7) \\
(24.2) \\
(22.0)\end{array}$ & $\begin{array}{r}237 \\
163 \\
32\end{array}$ & $\begin{array}{l}(72.3) \\
(75.3) \\
(78.0)\end{array}$ & $\begin{array}{r}397 \\
215 \\
+1\end{array}$ \\
\hline Total & .71 & $(26.2)$ & +82 & $(73.3)$ & 553 \\
\hline \multicolumn{6}{|l|}{ Acadente $\operatorname{lank}$. } \\
\hline 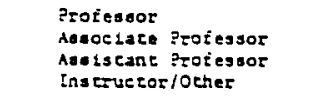 & $\begin{array}{r}93 \\
39 \\
: 7 \\
2\end{array}$ & $\begin{array}{l}(26.4) \\
(25.2) \\
(29.3) \\
(22.2)\end{array}$ & $\begin{array}{r}259 \\
175 \\
4 i \\
i\end{array}$ & $\begin{array}{l}(73.6) \\
(76.3) \\
(70.7) \\
(77.3)\end{array}$ & $\begin{array}{r}352 \\
234 \\
58 \\
9\end{array}$ \\
\hline Tocal & 171 & $(26.2)$ & $\angle 32$ & $(73.3)$ & 553 \\
\hline
\end{tabular}

- Four respondents did not ind teace Deparcment or Rank

The Data Analysis

The data analysis for this study was completed by selecting appropriate statistical programs from the (SPSS ${ }^{\mathrm{x}}$ ) Batch System. Among the research statistical techniques selected to study the data were: means, percentages, frequency distributions, reliability and ANOVA. More precisely, the Kruskal-Wallis nonparametric test was used to further explore the sum scores or to identify sub-groups of the respondents whose answers generated significantly different sub-scores.

A complete presentation and analysis of the study's data is presented in Chapter IV, with the conclusions drawn from the data present $\neq d$ in ihap $: e: V$. 
CHAPTER IV

PRESENTATION AND ANALYSIS OF THE DATA

\section{Introduction}

Chapter IV deals with the data and findings resulting from the study. The research instrument, "A Questionnaire to Study Collective Bargaining As a Process Adopted in Oregon's 4-Year Institutions of Higher Education to Support Faculty Members' Participation in Institutional Governance" was used to collect the data for this investigation.

To aid in the presentation and analysis of data, Chapter IV was written in two major sections. The first section presents the results of the demographic data specific to the three major areas of the research instrument: (1) Respondent Information, 2) Institutional Information, and (3) Institutional Governance Information.

The second section of Chapter IV presents an analysis of the interaction between select independent variables from Part I -Respondent Information of the research instrument and the dependent variables of the research model (1) professional interests, (2) economic interests, (3) educational policies, and (4) academic and personnel policies specific to Part III -- Institutional Governance Issues of the instrument. This statistical information was used to test the four hypotheses of the research study. 
H:l The collective bargaining process has affirmed the professional interests of the academician with an appointment in Oregon's 4-year institutions of higher education.

H:2 Collective bargaining, as implemented in Oregon's 4-year institutions of higher education, has provided for the academicians' participation in the planning and policy-making process related to the economic interests of the institution.

H:3 Faculty members with an academic appointment in Oregon's 4-year unionized institutions of higher education participate in determining the institution's educational policy on academic issues.

H:4 Collective bargaining has provided the faculty members in Oregon's 4-year institutions of higher education with the opportunity to participate in determining the academic and personnel policies of their employment.

Respondent Information

Years of Ful1-Time Teaching In A 4-Year Institution of Higher Education

Respondents $(\underline{N}=483)$ reported a range of less than 5 and more than 25 years of full-time academic teaching within a 4-year institution of higher education. While only 1 respondent had taught in higher education for fewer than 5 years, 72 of the total respondents had held an academic appointment for more than 25 years. As shown in Table XIII, the largest sub-group consists of those respondents who have taught between $16-20$ years in a 4-year system of higher education. 
TABLE XIII

\begin{tabular}{|c|c|c|c|c|c|c|}
\hline \multirow[b]{2}{*}{$\begin{array}{l}\text { Oregon's Unionized } \\
4-Y e a r \text { Institutions } \\
\text { of Higher Education }\end{array}$} & \multicolumn{6}{|c|}{$\begin{array}{l}\text { Years of Full Time Teaching Years in a } \\
4 \text {-Year Insticution of Higher Education }\end{array}$} \\
\hline & $\begin{array}{l}1-4 \\
\text { yrs. }\end{array}$ & $\begin{array}{l}5-10 \\
\text { yrs. }\end{array}$ & $\begin{array}{l}11-15 \\
\text { yrs. }\end{array}$ & $\begin{array}{r}16-20 \\
\text { yrg. }\end{array}$ & $\begin{array}{l}21-25 \\
\text { yrs. }\end{array}$ & $\begin{array}{l}\text { Over } \\
25 \text { yrs. }\end{array}$ \\
\hline $\begin{array}{l}\text { Western Oregon State Col. } \\
\text { Southern Oregon State Col. } \\
\text { Portland Stace University } \\
\text { Total Population }\end{array}$ & 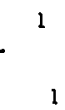 & $\begin{array}{l}6 \\
31 \\
37\end{array}$ & $\begin{array}{r}21 \\
27 \\
69 \\
117\end{array}$ & $\begin{array}{r}24 \\
34 \\
87 \\
145\end{array}$ & $\begin{array}{r}19 \\
27 \\
65 \\
111\end{array}$ & $\begin{array}{r}9 \\
12 \\
51 \\
72\end{array}$ \\
\hline
\end{tabular}

Membership in The American Association

of University Professors (AAUP)

In those Oregon 4-year institutions of higher education where academicians have selected collective bargaining as a supplemental governance mode, respondents at Western Oregon State College report only a $6.6 \%$ membership in AAUP, with a $6.3 \%$ membership reported at Southern Oregon State College and a $44.9 \%$ membership reported for Portland State University. As Table XIV illustrates, the majority of the respondents do not hold membership in AAUP. This includes a $55.1 \%$ non-membership reported by 206 respondents at Portland State University, where AAUP is the collective bargaining agent for faculty members' contracts. 
TABLE XIV

\begin{tabular}{|c|c|c|}
\hline \multirow{2}{*}{$\begin{array}{l}\text { Oregon's Unionized } \\
4 \text { 4ear Institutions } \\
\text { of Higher Education }\end{array}$} & \multicolumn{2}{|c|}{$\begin{array}{l}\text { Membership in (AAUP) American Asso- } \\
\text { clation of University Professors }\end{array}$} \\
\hline & Erequencies & Percent \\
\hline $\begin{array}{l}\text { Weatern Oregon State Col } \\
(N=76)\end{array}$ & 71 & $(6.6)(93.4)$ \\
\hline $\begin{array}{l}\text { Southern Oregon State Col. } \\
\qquad(N=95)\end{array}$ & 89 & $(6.3)(93.7)$ \\
\hline $\begin{array}{l}\text { Portland State Unfversity } \\
\qquad(N=296)\end{array}$ & 133 & $(44.9)(55.1)$ \\
\hline $\begin{array}{l}\text { Total Population } \\
(N=467)\end{array}$ & 144 & $(30.8)(69.2)$ \\
\hline
\end{tabular}

Faculty Members' Involvement In Institutional

Academic Collective Bargaining

The majority of the respondents reported nonparticipation in their institution's academic collective bargaining process. Table XV shows the extent of involvement in the collective bargaining process reported by respondents in each of the three unionized institutions.

TABLE XV

LEVEL OF INVOLVEMENT IN THE COLLECTIVE BARGAINING PROCESS, BY INSTITUTION

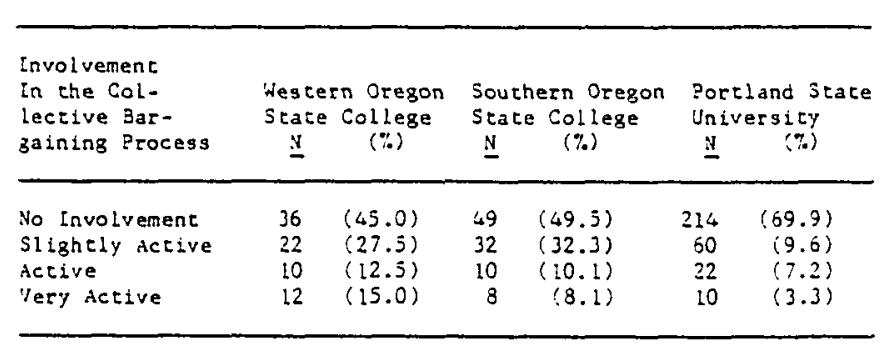


Analysis of involvement by institution indicates while $27.5 \%$ of Western Oregon State College faculty respondents were slightly involved in the collective bargaining process for their institution, $45 \%$ of the respondents selected to have no involvement in the process. This same pattern of respondent involvement in the bargaining process was reported at Southern Oregon State College where $32.3 \%$ of the respondents were slightly involved in the process and $49.5 \%$ of the faculty respondents selected no involvement in institutional bargaining. At Portland State University, $9.6 \%$ of the faculty respondents indicated they were slightly involved with the bargaining process; $69.9 \%$ have indicated nonparticipation in the process.

\section{Age of Respondents}

Table XVI shows the distribution of the faculty respondents' age range.

TABLE XVI

INSTITUTIONAL DISTRIBUTION OF RESPONDENTS BY AGE RANGE

\begin{tabular}{|c|c|c|c|c|c|}
\hline $\begin{array}{ll}\text { Employing } 4-Y e a r \\
\text { Unionized Institurion }\end{array}$ & $\begin{array}{l}30-39 \\
\mathrm{yrs}^{30}(\%)\end{array}$ & $\begin{array}{l}60-49 \\
y r s . \\
N \quad(\%)\end{array}$ & $\begin{array}{l}50-59 \\
y r s . \\
N \quad(\%)\end{array}$ & $\begin{array}{l}60 \text { or } \\
\text { above } \\
\mathrm{N}(\%)\end{array}$ & $\begin{array}{l}\text { Total } \\
\mathrm{N} \quad(\%)\end{array}$ \\
\hline
\end{tabular}

Western Oregon State Col. $2(2.5) \quad 29(36.5) 43(53.5) 6(7.5) 80(100)$ Southern Oregon State Col. $3(3.0) \quad 43(43.0) 42(42.0) 12(12.0) 100(100)$ Portland State Univergity $25 \quad(8.2) \quad 111(36.3) 115(37.8) 55$ (17.9) $306(100)$

$x^{2}=15.8, d f=6: p=.015 \quad N=486$

The respondents' age range in the study was from 30 to more than 60 years. The greatest percentage of Western Oregon State College respondents are in the 50-59 year age range. While at both Southern Oregon College $(\underline{\underline{n}}=43)$ and Portland State University $(\underline{n}=115)$ the 
greatest number of the respondents reported their age in the $40-49$

range.

Furthermore, as Table XVII illustrates, while the largest number of respondents holding the academic rank of professor were between 50-59 years of age, the largest group of associate professors who responded to this question were between $40-49$ years of age.

TABLE XVII

DISTRIBUTION OF RESPONDENTS BY ACADEMIC RANK AND AGE RANGE

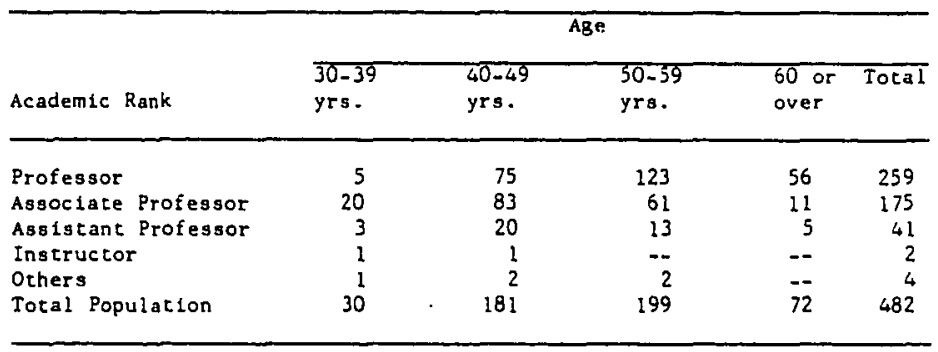

University/Departmental Academic

Governance Bodies

From the total population for the study $(\underline{N}=486)$, during the 1983-84 academic year, 259 respondents were appointed to a university or departmental governance committee.

Membership in the Faculty Academic Sencte was held by $28.1 \%$ of the Western Oregon State College respondents, by $33.3 \%$ of the 54 Southern Oregon State College total respondents and by $29.1 \%$ of the 148 Portland State University respondents.

While only $14.0 \%$ of the Western Oregon State College respondents and $20.4 \%$ of the Southern Oregon State College respondents were members 
of the institution's Rank and Tenure Committee, 33.1\% of Portland State's faculty respondents were appointed to this committee. Faculty respondents, as shown in Table XVIII, were least represented by membership appointment to the Institutional Finance Committees. At Portland State University, $3.4 \%$ of the respondents held an appointment to the comittee, while $8.8 \%$ of Western Oregon State College and $5.6 \%$ of Southern Oregon State College respondents reported an appointment to their Institutional Finance Committee(s).

Table XVIII

DISTRIBUTION OF RESPONDENTS BY UNIVERSITY/DEPARTMENTAL COVERNANCE BODIES AND THE EMPLOYING LNSTITUTION

\begin{tabular}{|c|c|c|c|}
\hline $\begin{array}{l}\text { University Depart- } \\
\text { mental Academic } \\
\text { Governance Bodfes }\end{array}$ & $\begin{array}{l}\text { Western Oregon } \\
\text { State College } \\
\text { i (7.) }\end{array}$ & $\begin{array}{l}\text { Souchern Oregon } \\
\text { State College } \\
\text { N } \quad \text { (II) }\end{array}$ & $\begin{array}{l}\text { Portland } \\
\text { Stace } \\
\text { University } \\
N \quad(7))\end{array}$ \\
\hline $\begin{array}{l}\text { Faculty Academic } \\
\text { Senace }\end{array}$ & $16(28.1)$ & $18(33.3)$ & $43(29.1)$ \\
\hline Finance Commitcee & $5 \quad(8.8)$ & $3(5.6)$ & $5(3.4)$ \\
\hline $\begin{array}{l}\text { Rank and Ienure } \\
\text { Caconittee }\end{array}$ & $8(14.0)$ & $11(20.4)$ & $49(33.1)$ \\
\hline $\begin{array}{l}\text { Other Pollcy-Making } \\
\text { Camitree }\end{array}$ & $28(49.1)$ & $22(40.7)$ & $51(34.5)$ \\
\hline Total & 57 & 54 & 148 \\
\hline
\end{tabular}

Further analysis indicates that the greater number (136) of the 259 respondents reporting an appointment to a governing committee (either in the department or university), held the academic rank of professor. The faculty respondent membership on the four governance committees listed on the research instrument: (1) faculty academic senate, (2) finance, (3) rank and tenure, and (4) other policy-making committees are shown in 
Table XIX.

During the 1983-84 academic year, in addition to the three specific governance committees used for the research instrument, respondents reported membership on such other policy-making committees as:

(1) Academic Requirements, (2) Curriculum, (3) Committee on Committees, (4) Teacher Education, and (5) Graduate Studies.

TABLE XIX

\begin{tabular}{|c|c|c|c|c|c|c|c|c|}
\hline \multirow{2}{*}{$\begin{array}{l}\text { University Depart- } \\
\text { mental Academic } \\
\text { Governance Combitcees }\end{array}$} & \multicolumn{2}{|c|}{ Professor } & \multicolumn{2}{|c|}{$\begin{array}{l}\text { Associate } \\
\text { Professor }\end{array}$} & \multicolumn{2}{|c|}{$\begin{array}{l}\text { Assiscant } \\
\text { Professor }\end{array}$} & \multicolumn{2}{|c|}{$\begin{array}{l}\text { Instructor/ } \\
\text { Other }\end{array}$} \\
\hline & $N$ & $(\%)$ & N & $(7)$ & $\mathbf{N}$ & $(\%)$ & N & $(\%)$ \\
\hline $\begin{array}{c}\text { Facul ey Academic } \\
\text { Senate }\end{array}$ & 42 & $(30.9)$ & 24 & $(26.4)$ & 9 & $(34.6)$ & 1 & - \\
\hline Finance Conmittee & 9 & $(6.6)$ & 2 & $(2.2)$ & 2 & $(7.7)$ & - & - \\
\hline $\begin{array}{l}\text { Rank and Tenure } \\
\text { Committee }\end{array}$ & 37 & $(27.2)$ & 24 & $(26.4)$ & 5 & $(19.2)$ & - & - \\
\hline $\begin{array}{l}\text { Other Policy-Making } \\
\text { Cominictee } \\
\text { Total }\end{array}$ & $\begin{array}{r}48 \\
136\end{array}$ & $(35.3)$ & $\begin{array}{l}41 \\
91\end{array}$ & $(45.1)$ & $\begin{array}{l}10 \\
26\end{array}$ & $(38.5)$ & i & - \\
\hline
\end{tabular}

\section{$\underline{\text { Salary }}$}

In the questionnaire seven intervals were provided to determine the salary range of the faculty respondents on a 9-month academic year contract during the $1983-84$ academic year. The respondents reported salaries ranging from $\$ 10,000$ to more than $\$ 40,000$ for $1983-84$ academic year contracts. While two respondents reported a salary between $\$ 10,000-\$ 15,000$ range, 176 of the respondents earned between $\$ 26,000-\$ 30,000$. Table XX provides a summary of the salary range. 
TABLE XX

DISTRIBUTION OF FACULTY SALARIES

\begin{tabular}{lcc}
\hline Salary Incervals & & \\
Dollars/9 months & Number & Percent \\
\hline $10,000-15,000$ & 2 & 0.4 \\
$16,000-20,000$ & 14 & 2.9 \\
$21,000-25,000$ & 129 & 26.7 \\
$26,000-30,000$ & 176 & 36.5 \\
$31,000-35,000$ & 108 & 22.4 \\
$36,000-40,000$ & 40 & 8.3 \\
$40,000-0 v e r$ & 13 & 2.7 \\
Total & $482 \star$ & 100 \\
\hline
\end{tabular}

FMissing values $=4$

Table XXI reports salaries by institution. The table reveals while two or $2.0 \%$ of the Southern Oregon State College respondents are in the $\$ 10,000-\$ 15,000$ salary range, 50 faculty respondents or half of their total respondents have salaries ranging from $\$ 26,000-\$ 30,000$. Portland State University also reported the greatest percentage, $33.6 \%$, of the 1983-84 respondents' salary contracts were in the $\$ 26,000-\$ 30,000$ interval. Western Oregon State College respondents reported 37 or $47.4 \%$ of the total respondents' salaries were between $\$ 21,000-\$ 25,000$ for 9 months, with 24 or $30.8 \%$ of the faculty respondents reporting a salary of $\$ 26,000-\$ 30,000$. 
TABLE XXI

SALARY DISTRIBUTION FOR FACULTY RESPONDENTS BY EMPLOYING ACADEMIC INSTITUTION

\begin{tabular}{|c|c|c|c|c|c|c|}
\hline $\begin{array}{l}\text { Solary Interval } \\
\text { Dollars } / 9 \text { month }\end{array}$ & \multicolumn{2}{|c|}{$\begin{array}{l}\text { Western Oregon } \\
\text { State College } \\
\mathrm{N} \quad(\%)\end{array}$} & \multicolumn{2}{|c|}{$\begin{array}{l}\text { Southern Oregon } \\
\text { State College } \\
\text { N }(\%)\end{array}$} & \multicolumn{2}{|c|}{$\begin{array}{l}\text { Portland Scate } \\
\text { University } \\
\mathrm{N}\end{array}$} \\
\hline $\begin{array}{l}10,000-15,000 \\
16,000-20,000 \\
21,000-25,000 \\
26,000-30,000 \\
31,000-35,000 \\
36,000-40,000 \\
\text { over } 40,000 \\
\text { Total }\end{array}$ & $\begin{array}{r}- \\
3 \\
37 \\
24 \\
6 \\
7 \\
1 \\
78\end{array}$ & $\begin{array}{r}(3.8) \\
(47.4) \\
(30.8) \\
(7.7) \\
(9.0) \\
(1.3)\end{array}$ & $\begin{array}{r}2 \\
1 \\
26 \\
50 \\
19 \\
2 \\
- \\
100\end{array}$ & $\begin{array}{c}2.0 \\
(1.0) \\
(26.0) \\
(50.0) \\
(19.0) \\
(2.0) \\
-\end{array}$ & $\begin{array}{r}- \\
10 \\
66 \\
102 \\
83 \\
31 \\
12 \\
304\end{array}$ & $\begin{array}{l}(3.3) \\
(21.7) \\
(33.6) \\
(27.3) \\
(10.2) \\
(3.9)\end{array}$ \\
\hline
\end{tabular}

Further examination of the salary ranges shows that in all three academic areas the greatest percentage of the faculty respondents employed are within the salary interval of $\$ 26,000-\$ 30,000$ for the 1983-1984 academic year on a 9 month's contract. The percentages of faculty respondents in the $\$ 26,000-\$ 30,000$ salary interval by academic areas were: Liberal Arts, 38.6\%; Professional Schools, 34.0\%; Others $32.2 \%$ (See Table XII).

TABLE XXII

DISTRIBUTION OF SALARY BY ACADEMIC AREA FOR FACULIY RESPONDENTS

\begin{tabular}{|c|c|c|c|c|c|c|}
\hline \multirow{3}{*}{$\begin{array}{l}\text { Salary Interval } \\
\text { Dollars/9 months }\end{array}$} & \multicolumn{6}{|c|}{ Academic Area } \\
\hline & \multicolumn{2}{|c|}{$\begin{array}{l}\text { Liberal Arts: } \\
\text { College/ } \\
\text { Department/ } \\
\text { School }\end{array}$} & \multicolumn{2}{|c|}{$\begin{array}{l}\text { Professional } \\
\text { School }\end{array}$} & \multicolumn{2}{|c|}{ Others } \\
\hline & $\underline{\mathbf{N}}$ & $(\%)$ & $\underline{N}$ & $(\%)$ & $\underline{\mathrm{N}}$ & $(\%)$ \\
\hline $\begin{array}{c}10,000-15,000 \\
16,000-20,000 \\
21,000-25,000 \\
26,000-30,000 \\
31,000-35,000 \\
36,000-40,000 \\
\text { over } 40,000 \\
\text { Total }\end{array}$ & $\begin{array}{r}1 \\
6 \\
87 \\
110 \\
61 \\
13 \\
7 \\
285\end{array}$ & $\begin{array}{r}(0.4) \\
(2.1) \\
(30.5) \\
(38.6) \\
(21.4) \\
(4.6) \\
(2.5)\end{array}$ & $\begin{array}{r}1 \\
5 \\
32 \\
55 \\
40 \\
24 \\
5 \\
162\end{array}$ & $\begin{array}{l}(0.6) \\
(3.1) \\
(19.8) \\
(34.0) \\
(24.7) \\
(14.8) \\
(3.1)\end{array}$ & $\begin{array}{r}5 \\
9 \\
10 \\
6 \\
3 \\
3 i\end{array}$ & $\begin{array}{c}(9.7) \\
(29.0) \\
(32.3) \\
(19.4) \\
(9.7) \\
-\end{array}$ \\
\hline
\end{tabular}


Additional analysis revealed that of the 478 faculty respondents reporting their salary ranges, $37.2 \%$ or 96 of the respondents with the academic rank of professor earned between $\$ 26,000-\$ 30,000$ for a 9 months' academic year appointment. While 80 or $46.2 \%$ of the respondents with the academic rank of associate professor earned between $\$ 21,000-\$ 25,000,67.5 \%$ or 27 of the respondents holding the rank of assistant professor were employed in the same salary range. Table XXIII presents respondents' salaries within the four academic ranks of the university system.

TABLE XXIII

SALARY LNTERVAL DISTRIBUTION OF FACULTY RESPONDENTS BY ACADEMIC RANK

\begin{tabular}{|c|c|c|c|c|}
\hline \multirow[b]{2}{*}{$\begin{array}{l}\text { Salary Interval } \\
\text { Dollarg/9 months }\end{array}$} & \multicolumn{4}{|c|}{ Academ $1 \mathrm{c} \operatorname{Rank}$} \\
\hline & $\begin{array}{l}\text { Protessor } \\
N \quad(\%)\end{array}$ & $\begin{array}{l}\text { Assoctate } \\
\text { Protessor } \\
N \quad(7)\end{array}$ & $\begin{array}{l}\text { dsolstanc } \\
\text { Proiessior } \\
\text { N (7.) }\end{array}$ & $\begin{array}{l}\text { instructorl } \\
\text { Orher } \\
\underline{N} \quad \text { (\%) }\end{array}$ \\
\hline $\begin{array}{l}10,000-15,000 \\
16,000-20,000 \\
21,000-25,000 \\
26,000-30,000 \\
31,000-35,000 \\
36,000-40,000 \\
\text { over } 40,000 \\
\text { Total }\end{array}$ & $\begin{array}{rr}1 & (0.4) \\
2 & (0.3) \\
18 & (7.0) \\
96 & (37.2) \\
95 & (36.8) \\
34 & (13.2) \\
12 & (4.7) \\
258 & \end{array}$ & $\begin{array}{rc}1 & (0.5) \\
6 & (3.5) \\
80 & (46.2) \\
74 & (42.3) \\
7 & (4.0) \\
5 & (2.9) \\
- & - \\
173 & \end{array}$ & $\begin{array}{rc}- & (10.0) \\
4 & (107.5) \\
27 & (670.0) \\
4 & (10.0) \\
4 & (10.0) \\
1 & (2.5) \\
40 & -\end{array}$ & $\begin{array}{cc}- & - \\
1 & (1.0) \\
- & (2.0) \\
1 & (1.0) \\
- & (1.0) \\
- & - \\
\overline{2} & -\end{array}$ \\
\hline
\end{tabular}

Institutional Influences

Introduction

The data for the second main area of the research instrument are presented to identify those contextual factors, either external or internal to a 4-year university system, which were perceived in 1983 to be an influencing factor in faculty respondents' decision to vote for a new institutional academic collective bargaining contract. 
Those faculty respondents voting for a new institutional contract responded to 13 statements on the research instrument. The issues specific to each statement had the potential to affect the governance structure and functions of the institution. Using a 5-point Likert Scale, voting faculty respondents recorded their response to the 13 listed factors as an influencing or non-influencing factor in their decision to vote for a contract renewal.

A total presentation of the respondents' data specific to each of the 13 statements is illustrated by Table XXIV (See Appendix I). The frequency of response, as well as the percentage based upon the total number of responses for each statement, is presented.

The data can be further statistically analyzed to present additional important findings specific to each of four data subsets:

(1) funding, (2) decision-making process/bodies, (3)organizational change, and (4) students. These findings are as follows:

(1) Funding - the impact that federal, state, or institutional funding had on the conduct of faculty research or program development in the subject institution formed questions $8,9,11$ of the research instrument.

While 114 of the faculty members were in disagreement with statement 9, "Federal funds approprlated for research have been reduced," 111 of the 419 respondents were undecided about the statement as a contextual factor of significance to them in voting for contract renewal in 1983.

Statements 8 and 11 , as shown in Table XXV, were reported as 
significant contextual factors in the respondents' decision to vote for a contract renewal. At Southern Oregon State College, 42 of the total 90 respondents and 104 of the 261 respondents from Portland State University reported they strongly agree with statement 8 , "State legislative funding was reduced for your institution." Furthermore, the importance of state funding as an influencing force is agreed upon by 104 of the Portland State University respondents and 33 of the 72 respondents from Western Oregon State College.

Statement 11, "Limited instructional funds have decreased the development of academic programs" was reported as a significant contextual factor for 177 of the 423 respondents voting in 1983 for a contract renewal. A further analysis of the statement by academic institution (See Table XXV) shows the statement was of significance to faculty members holding an academic appointment during the 1983-84 academic year, in each of the three unionized 4-year institutions in Oregon's system of higher education.

(2) Decision-Making Process/Bodies important to faculty members' governance and function within the academy were studied by questions 12 through 16 of the research instrument.

To statement 14, "The faculty senate/council has become less effective as governance bodies," and 16 , "There was a reduced sense of collegiality among faculty," the investigator found respondents in each of the three unionized 4-year institutions agreed that these were significant contextual factors in their decision to vote for a contract renewal. As demonstrated in Table XXVI, 30 of the 70 Western Oregon 
TABLE XXV

DISTRIBUTION OF RESPONDENTS ANSHERS TO QUESTIONS

8 AND 11 OF THE RESEARCH INSTRUMENT BY

THE EMPLOYING ACADEHIG SETTING

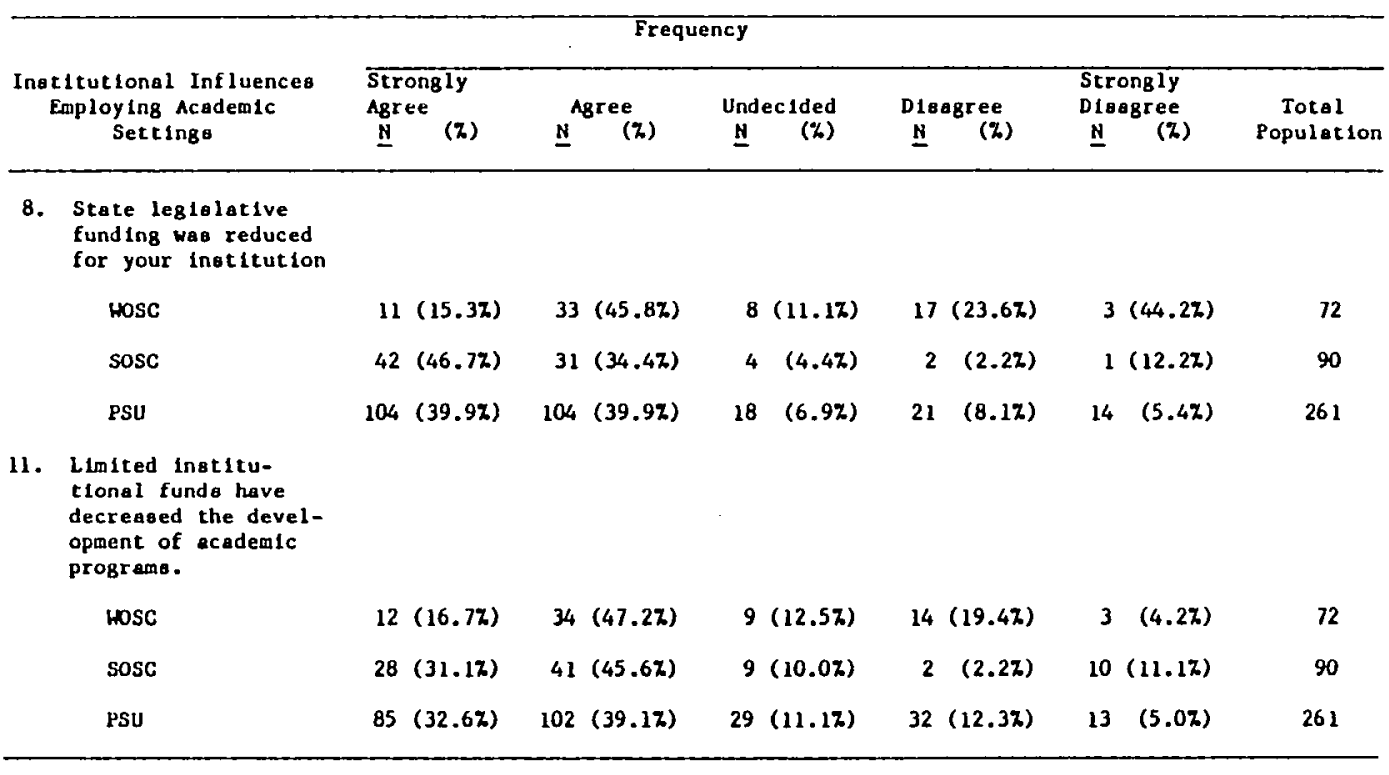


State College respondents, 26 of the 90 Southern Oregon State College respondents, and 93 of Portland State University's 260 respondents agreed with statement 14 . In response to statement 16 , the investigator found that 24 of the 70 Western Oregon State College respondents, 33 of the 90 Southern Oregon State College respondents and 91 of the Portland State University 260 respondents recorded agreement with the statement. Statements 13 and 15 of the research instrument focused on the impact of the decision-making process, as related to the development of educational policy for the institutions at the state and departmental level of governance.

To statement 13, (See Table XXVII) "The educational policy decision-making rights of the central administration were controlled by the state education agency," 82 of Portland State University's total 259 respondents recorded agreement with the statement, as did 23 of the respondents from Southern Oregon State College. At Western Oregon State College only 19 of the 70 respondents agreed with the statement, while 28 or $34.3 \%$ disagreed that this statement was a significant contextual factor in their decision to vote for a new institutional academic collective bargaining contract.

As illustrated in Table XXVII, 82 of the 261 Portland State University respondents answered in agreement with statement 15; "There was a decline in the faculty members' influence in policy-making at the departmental level," while 80 respondents disagreed that the statement was a significant factor in their collective bargaining voting. Twenty-eight or $40.0 \%$ of the Western Oregon State College faculty 
TABLE: $X X V 1$

DISTRIBUTION OF RESPONDENTS ACCORDING: TO QUESTIONS

14 AND 16 OF THE RESEARCH INSTHUMENT BY

\begin{tabular}{|c|c|c|c|c|c|c|}
\hline \multirow[b]{2}{*}{$\begin{array}{c}\text { Institulional Intluence } \\
\text { Employing Academic } \\
\text { SetLings }\end{array}$} & \multicolumn{5}{|c|}{ Frequency } & \multirow[b]{2}{*}{$\begin{array}{l}\text { Total } \\
\text { Populatior }\end{array}$} \\
\hline & $\begin{array}{l}\text { Strongly } \\
\text { Agree } \\
\underline{N} \quad \text { (\%) }\end{array}$ & $\begin{array}{l}\text { Agree. } \\
\underline{N}^{\text {Ans }}(\%)\end{array}$ & $\begin{array}{l}\text { Undec ided } \\
\underline{N} \quad(\%)\end{array}$ & $\begin{array}{l}\text { Disagret } \\
N \quad(\%)\end{array}$ & $\begin{array}{l}\text { Strongly } \\
\text { Disagree } \\
\underline{N} \quad(\%)\end{array}$ & \\
\hline $\begin{array}{l}\text { 14. The faculicy academic } \\
\text { senale/ council has } \\
\text { become less ef fectuve } \\
\text { as a governance body. }\end{array}$ & & & & & & \\
\hline wosc & $6(8.6 \%)$ & $30(42.9 \%)$ & $9(12.9 \%)$ & $19(27.1 \%)$ & $6 \quad(8.6 \%)$ & 70 \\
\hline $\operatorname{sosc}$ & $20(22.2 \%)$ & $26(28.9 \%)$ & $11(12.2 \%)$ & $21(23.3 \%)$ & $12(13.3 \%)$ & 90 \\
\hline $\begin{array}{l}\text { PSU } \\
\text { 16. There was a reduced } \\
\text { sense of collegiality } \\
\text { among the faculty. }\end{array}$ & $33(12.6 \%)$ & $93(35.6 \%)$ & $56(21.5 \%)$ & $62(23.8 \%)$ & $17(6.5 \%)$ & 261 \\
\hline Hosc & $10(13.9 \%)$ & $24(33.3 \%)$ & $10(13.9 \%)$ & $21(29.2 \%)$ & $7 \quad(9.7 \%)$ & 72 \\
\hline sosc & $13(14.4 \%)$ & $33(36.7 \%)$ & $15(16.7 \%)$ & $16(17.87)$ & $13(14.4 \%)$ & 90 \\
\hline PSU & $49(18.9 z)$ & $91(35.0 \%)$ & $36(13.9 \%)$ & $62(23.9 \%)$ & $22(18.5 \%)$ & 260 \\
\hline
\end{tabular}


TABLE XXVII

DISTHIBUTION OF FACULTY RESPONSES TO QUESTLONS

13 AND IS OF THE RESEAKCH INSTRUMENT BY

EMPLOYING ACADFMIC INSTITUTION

\begin{tabular}{|c|c|c|c|c|c|c|c|c|c|c|}
\hline \multirow{3}{*}{\multicolumn{2}{|c|}{$\begin{array}{l} \\
\text { Institutional Influences } \\
\text { Employing Academic } \\
\text { Setlings }\end{array}$}} & \multicolumn{9}{|c|}{ Frequency } \\
\hline & & \multirow{2}{*}{\multicolumn{2}{|c|}{$\begin{array}{l}\text { Strongly } \\
\text { Agree } \\
\underline{N} \quad(\%)\end{array}$}} & \multicolumn{2}{|c|}{ Agree } & \multicolumn{2}{|c|}{ Undecided } & Disagree & $\begin{array}{l}\text { Strongly } \\
\text { Disagrete }\end{array}$ & \multirow{2}{*}{$\begin{array}{l}\text { Total } \\
\text { Population }\end{array}$} \\
\hline & & & & $\underline{N}$ & (z) & & & & $\underline{N} \quad(\%)$ & \\
\hline \multirow[t]{4}{*}{13.} & $\begin{array}{l}\text { The educational pol- } \\
\text { ley decision-making } \\
\text { rights of the ingti- } \\
\text { tution's central ad- } \\
\text { ministration were } \\
\text { controlled by the } \\
\text { atate educational } \\
\text { agency. }\end{array}$ & & & & & & . & & & \\
\hline & Hosc & 4 & $(5.7 \%)$ & 19 & $(27.1 \%)$ & 14 & $(20.2 \%)$ & $28(34.3 \%)$ & $12(12.9 \%)$ & 70 \\
\hline & sosc & 12 & $(13.37)$ & 23 & $(25.6 \%)$ & 22 & $(24.4 \%)$ & $22(24.4 \%)$ & $\|(12.1 \%)$ & 90 \\
\hline & PSu & 32 & $(12.4 \%)$ & 82 & $(31.7 \%)$ & 62 & $(23.9 \%)$ & $61(23.6 \%)$ & $22 \quad(8.52)$ & 259 \\
\hline \multirow[t]{4}{*}{15.} & $\begin{array}{l}\text { There was a decline } \\
\text { in the faculsy mem- } \\
\text { hers' influences on } \\
\text { policy deciston- } \\
\text { making at the de- } \\
\text { partmental level. }\end{array}$ & & & & & & & & & \\
\hline & HOSC & 12 & $(17.1 \%)$ & 28 & $(40.0 \%)$ & 3 & $(4.3 \%)$ & $20(28.6 \%)$ & $7(10.0 \%)$ & 70 \\
\hline & sosc & 10 & $(11.1 \%)$ & 17 & $(18.9 \%)$ & 15 & $(16.7 \%)$ & $28(31.1 \%)$ & $20(22.2 \%)$ & 90 \\
\hline & PSU & 49 & $(18.8 \%)$ & 82 & $(31.4 \%)$ & 23 & $(8.8 \%)$ & $80(30.7 \%)$ & $27(10.3 \%)$ & 261 \\
\hline
\end{tabular}


recorded agreement with the statement, while 28 or $31.1 \%$ of the Southern Oregon State College respondents disagreed that the statement was of significance to their institution.

(3) Organizational changes -- statement(s) 10, 18 and 19 of the research instrument address those factors in the organizational structures and functions that can influence a faculty member to vote in support of academic collective bargaining as a supplemental governance mode for an institution. Specific data analysis of the questions reveals the following:

(A) A substantive number of the institutional respondent subsample groups disagree with statement 10, "The structural size of the institution has grown rapidly during the preceding five years." As shown in Table XXVIII, 42 of the 68 Western Oregon State College respondents, 60 of the Southern Oregon State College 86 total respondents, as well as 149 of the 215 Portland State University respondents recorded a disagreement with the statement.

(B) About half of the Portland State University respondents recorded disagreement with statements 18 and 19 (See Table XXVIII). However, statement 18, "The institution has developed and implemented a new mission and goal statement," was a significant contextual factor to respondents at Western Oregon State College where 34 of the 71 respondents were in agreement that a new mission and goal statement(s) had been developed and implemented in their university system. 
TABLE XXVIII

DISTRIBUTION OF FACULTY RESPONSES TO QUESTIONS

10, 18, AND 19 OF TIIE RESEARCH INSTRUMENT

BY EMI'LOYING ACADEMIC INSTITUTION

\begin{tabular}{|c|c|c|c|c|c|c|c|c|}
\hline & & & & & Frequency & & & \\
\hline Inst & $\begin{array}{l}\text { ILutional Influences } \\
\text { mployitug Acadectic } \\
\text { Sellings }\end{array}$ & $\begin{array}{l}\overline{\text { Sirc }} \\
\text { Agre } \\
\underline{N}\end{array}$ & $\begin{array}{l}\text { ngly } \\
(\%)\end{array}$ & $\underline{N}^{\text {Agree }}(\%)$ & $\begin{array}{l}\text { Unufecided } \\
\underline{N} \quad(\%)\end{array}$ & $\begin{array}{l}\text { Disagree } \\
\underline{N} \quad(\%)\end{array}$ & $\begin{array}{l}\text { SLrongly } \\
\text { Disagree } \\
\underline{N} \quad(\%)\end{array}$ & $\begin{array}{l}\text { Total } \\
\text { Pupulation }\end{array}$ \\
\hline & $\begin{array}{l}\text { The structural olize } \\
\text { of the institution } \\
\text { has grown rapidily } \\
\text { during the preceding } \\
\text { fiscal year. }\end{array}$ & & & & & & & \\
\hline & Hosc & 2 & $(2.9 \%)$ & $9(19.1 \%)$ & $16(13.2 \%)$ & $26(38.27)$ & $16(20.5 \%)$ & 68 \\
\hline & sosc & 6 & $(7.0 \%)$ & $11(12.8 \%)$ & $9(10.5 \%)$ & $31(36.1 \%)$ & $29(33.7 \%)$ & 86 \\
\hline & PSU & 8 & $(3.1 \%)$ & $38(14.7 \%)$ & $63(24.4 \%)$ & $95(36.8 \%)$ & $54(20.9 \%)$ & 258 \\
\hline 18. & $\begin{array}{l}\text { The institution has } \\
\text { developed and imple- } \\
\text { mented new anision and } \\
\text { goal stacemente. }\end{array}$ & & & & & & & \\
\hline & HOSC & 4 & $(5.6 \%)$ & $30(42.3 \%)$ & $12(16.9 \%)$ & $19(26.8 \%)$ & $6 \quad(8.5 \%)$ & 71 \\
\hline & $\operatorname{sosc}$ & 4 & $(4.5 \%)$ & $23(25.8 \%)$ & $26(29.2 \%)$ & $18(20.2 \%)$ & $18(20.27)$. & 89 \\
\hline & psu & 4 & (1. $5 \%)$ & $43(16.67)$ & $74(28.6 \%)$ & $98(37.8 \%)$ & $40(15.4 \%)$ & 259 \\
\hline 19. & $\begin{array}{l}\text { The insticution has de- } \\
\text { algned and inplemented } \\
\text { a new organizat lonal } \\
\text { structure. }\end{array}$ & & & & & & & \\
\hline & hosc & & $(12.9 \%)$ & $39(55.7 \%)$ & $6 \quad(8.6 \%)$ & $13(18.5 \%)$ & $3 \quad(4.3 \%)$ & 20 \\
\hline & sosc & 7 & $(7.9 \%)$ & $26(29.27)$. & $22(24.77)$ & $17(19.1 \%)$ & $17(19.1 \%)$ & 89 \\
\hline & PSU & 9 & (3.5\%) & $60(23.2 \%)$ & $74(28.6 \%)$ & $81(31.3 \%)$ & $35(13.5 \%)$ & 259 \\
\hline
\end{tabular}


Furthermore, statement 19 , "The institution has designed and implemented a new organizational structure," was identified as an influencing factor for 70 faculty members at Western Oregon State College, where 48 or $68.6 \%$ of the respondents recorded agreement with the statement. In addition, 33 of the total 89 respondents at Southern Oregon State College agreed that their decision to vote for contract renewal had been influenced by a new institutional organizational design and structure. However, 34 of the institution's respondents were in disagreement with the statement.

D. Students

Statements 7 and 17 on the questionnaire are specific to student issues, which could be perceived as influencing factors in a faculty member's decision to support academic collective bargaining.

While only 45 of 421 respondents agreed with statement 17, "Student power has increased on the campus," a decline in student enroliment was identified as an influencing factor by 40 or $55.5 \%$ of the total 72 respondents (See Table XXIX) from Western Oregon State College in their decision to vote for a renewal of the institutional bargaining contract.

\section{Institutional Governance Information}

Introduction

Academic institutional governance was the third area of inquiry for 


\section{TABLE XXIX}

DISTRIBUTION OF FACULTY RESPONSES TO QUESTIONS SEVEN INSTRUMENT BY EMPLOYING ACADEMIC INSTITUTION

\begin{tabular}{|c|c|c|c|c|c|c|c|}
\hline \multirow[b]{2}{*}{$\begin{array}{c}\text { Instizutional Influence } \\
\text { Einploying Academic } \\
\text { Sectings }\end{array}$} & \multicolumn{6}{|c|}{ Frequency } & \multirow[b]{2}{*}{$\begin{array}{l}\text { Total } \\
\text { Population }\end{array}$} \\
\hline & \multicolumn{2}{|c|}{$\begin{array}{l}\text { Strungly } \\
\begin{array}{cl}\text { Agree } \\
\underline{N} \quad(\%)\end{array}\end{array}$} & $\underline{N}^{\text {Agree }}(\%)$ & $\begin{array}{l}\text { Undecided } \\
\mathrm{N} \quad(\%)\end{array}$ & Disagree & $\begin{array}{l}\text { Strungly } \\
\text { Disagree }\end{array}$ & \\
\hline $\begin{array}{l}\text { 7. The Institurion was } \\
\text { exper lencing a de- } \\
\text { cline in student } \\
\text { enrol lment. }\end{array}$ & & & & & & & \\
\hline Hosc & & $(11.1 \%)$ & $32(44.4 \%)$ & $4 \quad(5.6 \%)$ & $16(22.2 \%)$ & $12(16.7 \%)$ & 72 \\
\hline sosc & 2 & $(2.3 \%)$ & $10(11.4 \%)$ & $15(17.1 \%)$ & $30(34.1 \%)$ & $31(35.2 \%)$ & 88 \\
\hline PSU & 16 & $(3.2 \%)$ & $67(25.9 \%)$ & $47(18.2 \%)$ & $86(33.2 \%)$ & $43(16.6 \%)$ & 259 \\
\hline \multicolumn{8}{|l|}{$\begin{array}{l}\text { 17. Student power has } \\
\text { increased on the } \\
\text { campus. }\end{array}$} \\
\hline HOSC & 2 & $(2.8 \%)$ & $7 \quad(9.9 \%)$ & $13(18.3 \%)$ & $32(45.1 \%)$ & $17(23.9 \%)$ & 71 \\
\hline sosc & 0 & $(0.0 \%)$ & $17(18.9 \%)$ & $7 \quad(7.8 \%)$ & $41(45.6 \%)$ & $25(27.8 \%)$ & 90 \\
\hline PSU & 0 & $(0.0 \%)$ & $19 \quad(7.3 \%)$ & $50(19.7 \%)$ & $125(48.1 \%)$ & $66(25.9 \%)$ & 260 \\
\hline
\end{tabular}


this study. This process includes both the formal decision-making structures used within a university system, which have the potential to affect relationships, procedures and policies.

Four sub-sets of data are presented. (1) professional interests, (2) economic interests, (3) educational policies, and (4) academic/ personnel policies specific to academic governance issues.

\section{Professional Interests}

The first subset of data specific to academic governance includes respondents'. reported perceptions to the impact that academic collective bargaining had upon their professional prestige within the employing institution.

As shown in Table $\mathrm{XXX}$ (See Appendix $\mathrm{J}$ ), the research instrument studied eight professional interest statements. As the data reveals, respondents were in disagreement or strong disagreement with seven statements $(20,21,23,24,25,26,27)$ of the survey. In brief, the data suggest respondents do not agree that academic collective bargaining has provided them with:

(1) An academic milieu supportive of the pursuit of scholarship.

(2) A collegial relationship with administration.

(3) A professional, rather than employee, status to their role in the institution.

(4) An increased interest in the function and role of the faculty senate/council.

(5) Involvement in the selection process for the appointment of an administrator to a central or departmental administration 
position.

(6) An influence in setting institutional standards for academic performance.

(7) The right to participate in policy-making on educational issues that have the potential to affect public opinion about the institution.

However, to statement No. 22 (See Table XXXI), 226 of the 474 respondents agreed that academic collective bargaining has provided them with "a formalized structure and process for institutional decision-making" in their employing university system.

\section{Economic Interests}

The second subset of data specific to academic governance is respondents' reported perception to academic collective bargaining as a facilitator for institutional economic interests.

As illustrated in Table XXXII (see Appendix K), the data suggest that, as an aggregate, the respondents do not agree academic collective bargaining has: (1) provided the faculty with a higher public profile specific to budgetary issues in Oregon's system of higher education, (2) encouraged the university budgetary affairs committee to link budget planning to institutional academic goals, (3) provided for faculty input into the long-range budgeting planning modes of the institution, or (4) generated additional money for the faculty salary scale in Oregon's system of higher education.

However, additional analysis of the data (See Table XXXIII) 
TABLE XXXI

FACULTY MEMBEHS' PERCEPTIONS OF THE IMPACT OF ACADEMIC COLLECTIVE BARGAINING ON
INSTITUTIONAL STRUCTURE/PROCESS

\begin{tabular}{|c|c|c|c|c|c|c|}
\hline \multirow{3}{*}{$\begin{array}{l}\text { Institultonal Governance Information } \\
\text { Employing Academic Selling }\end{array}$} & \multicolumn{5}{|c|}{ Frequency } & \multirow{3}{*}{$\begin{array}{l}\text { Total } \\
\text { Respondents }\end{array}$} \\
\hline & $\begin{array}{l}\text { Sirongly } \\
\text { Agree }\end{array}$ & Agree & $\begin{array}{l}\text { Unde- } \\
\text { cided }\end{array}$ & $\begin{array}{l}\text { Dis- } \\
\text { agree }\end{array}$ & $\begin{array}{l}\text { Strongly } \\
\text { Disagree }\end{array}$ & \\
\hline & $\underline{N} \quad(\%)$ & $\underline{N} \quad(\%)$ & & & & \\
\hline
\end{tabular}

22. A formalized structure and

process for institutional deçiaion-making

wosc

$\operatorname{sosc}$

PSU

$15(19.2 \%) 32(41.0 \%)$

$6(7.7 \%) \quad 31(26.9 \%)$

4 (5. $1 \%)$

78

$8 \quad(8.3 \%) \quad 36(37.5 \%) \quad 12(12.5 \%) \quad 24(25.0 \%) \quad 16(16.7 \%) \quad 96$

$29(9.7 \%) 106(35.3 \%) \quad 60(20.0 \%)$

$74(24.7 \%) \quad 31(10.3 \%$

300

Total Regponse日

52

174

78

119

51

474 
TABL.E $x \times x 111$

RESPONDENTS ' PERCEPTIONS TO STATEMENTS

$(29,30,31,34$ OH 36$)$ ECONOMIC

\begin{tabular}{|c|c|c|c|c|c|c|c|c|}
\hline \multirow[b]{2}{*}{ Insfitution } & \multirow[b]{2}{*}{$\begin{array}{l}\text { Econamic Interest } \\
\text { Stacement }\end{array}$} & \multicolumn{6}{|c|}{ Frequency } & \multirow[b]{2}{*}{$\begin{array}{l}\text { Total } \\
\text { Respondents }\end{array}$} \\
\hline & & $\begin{array}{l}\text { Strongly } \\
\text { Agreet } \\
N \quad(7)^{\circ}\end{array}$ & $\begin{array}{c}\text { Agree } \\
\mathrm{N}^{\text {Agre }}(\%)\end{array}$ & & $\begin{array}{l}\text { Unde- } \\
\text { clued } \\
\quad \text { (\%) }\end{array}$ & $\begin{array}{c}\text { Dis- } \\
\text { agree } \\
\underline{N} \quad(\%)\end{array}$ & $\begin{array}{l}\text { Strongly } \\
\text { Disagree } \\
\mathrm{N} \%\end{array}$ & \\
\hline \multirow[t]{4}{*}{$\begin{array}{l}\text { Southern } \\
\text { oregon State } \\
\text { College }\end{array}$} & $\begin{array}{l}\text { 29. Clarify the problem } \\
\text { of a low faculcy aalary } \\
\text { schedule in Oregon's } \\
\text { systers of higher edu- } \\
\text { catlon. }\end{array}$ & $9(9.3 \%)$ & $44(45.4 \%)$ & 10 & $D(10.3 \%)$ & $16(16.5 \%)$ & $18(18.62)$ & 97 \\
\hline & $\begin{array}{l}\text { 30. Increased the importance } \\
\text { of budgetary/financial } \\
\text { affairs commiztee's role } \\
\text { in university budget an- } \\
\text { alyoig and planning. }\end{array}$ & $4(4.1 \%)$ & $39(39.8 \%)$ & 26 & $(26.5 \%)$ & $19(19.4 \%)$ & $10(10.2 \%)$ & 98 \\
\hline & $\begin{array}{l}\text { 31. Strengthen your input } \\
\text { into short-range univer- } \\
\text { sity budgel planning and } \\
\text { deciston-making. }\end{array}$ & $4(4.2 \%)$ & $30(39.6 \%)$ & 19 & $(19.8 \%)$ & $22(22.9 \%)$ & $13(13.5 \%)$ & 98 \\
\hline & $\begin{array}{l}\text { 34. Assisted the faculty and } \\
\text { adminiscration to present } \\
\text { a united agreement to the } \\
\text { otate legislature. }\end{array}$ & $7(7.3 \%)$ & $31(32.0 \%)$ & 28 & $(28.9 \%)$ & $17(17.5 \%)$ & $14(14.47 \%)$ & 97 \\
\hline $\begin{array}{l}\text { Portland } \\
\text { State } \\
\text { University }\end{array}$ & $\begin{array}{l}\text { 29. Clarify the problem } \\
\text { of a low faculey aalary } \\
\text { schedule in Oregon's } \\
\text { systern of higher edu- } \\
\text { cation. }\end{array}$ & $32(10.7 \%)$ & $105(35.2 \%)$ & 42 & $(14.1 \%)$ & $92(30.9 \%)$ & $27(9.1 \%)$ & 298 \\
\hline $\begin{array}{l}\text { Hestern } \\
\text { Oregon State } \\
\text { College }\end{array}$ & $\begin{array}{l}\text { 30. Increased the Importance } \\
\text { of budgetary/f Inancial } \\
\text { affairs commltiee's role } \\
\text { in university budget an- } \\
\text { alyois and planning. }\end{array}$ & $3(6.3 \%)$ & $31(25.3 \%)$ & 10 & $(8.9 \%)$ & $26(34.27)$ & $9(25.3 \%)$ & 79 \\
\hline
\end{tabular}


suggests that the academic collective bargaining process, for many Southern Oregon College respondents, is perceived as having (1) clarified the problem of a low faculty salary schedule in Oregon's system of higher education, (2) increased the importance of the budgetary/financial affairs committee's role in university budget analysis and planning, (3) assisted the faculty and administration to present a united agreement to the state legislature, and (4) increased their salary and fringe benefits for the system.

Furthermore, this analysis reveals that while 137 of the 298 Portland State University respondents agree with statement 29 of the research instrument, which states that "collective bargaining clarified the problem of a low faculty salary schedule in Oregon's system of higher education," 119 respondents disagreed with the statement.

In addition, 35 of the 79 Western Oregon State College respondents agree that the collective bargaining process has provided an "increase in the importance of the budgetary/financial affairs comittee's role in university budget analysis and planning." However, 35 of the 79 respondents disagreed with the statement.

\section{Educational Policies}

The academic community has established a tradition to assure the academician's rights for active participation in determining the educational policies of a university system, as well as establishing those institutional procedures that govern the educational process: (1) teaching, (2) programs, or (3) students (Sands, 1971). This right for the academician may be further supported in the university setting 
by the acceptance of collective bargaining as a supplemental governance mode.

In Oregon, data (See Table XXXIV) of this study suggest faculty respondents do not agree that it has been necessary to implement academic collective bargaining in order to assure the faculty members' right to determine educational policies and procedures in their institutions. Their perceptions are further supported by the following select respondents' comments: (1) "Collective Bargaining has had no effect here. Faculty participation remains the same," (2) "No effect," 3) "Collective Bargaining is only one factor, and a minor one," (4) "No difference now than before collective bargaining," (5) "We never have a problem in this area," (6) "To a large extent, these were already in place."

Academic and Personnel Policies

University educators have the primary governance authority for all matters related to faculty status (AAUP, 1984). This study investigated collective bargaining's impact in providing the opportunity for faculty members employed in Oregon's unionized institutions to participate in determining policies related to:

(1) academic duties, (2) academic standards and personnel policies, and (3) support services. For this data subset, the respondents were requested to record their responses on a four-part scale: (1) always, (2) frequently, (3) infrequently, and (4) never. As shown in Table XXXV, the responses to items 44,45 , and 46 of the research instrument indicate that the acceptance of collective 
TABLE XXXIV

FACUITY MEMHE:HS' PERCEPTION OF THE IMPACT OF ACADEMIC COLLLETIVE HARGAINING ON EDUCATIONAL. POLICY
DETERMINANTS IN INSTITUTIONAL COVERNANCE

\begin{tabular}{|c|c|c|c|c|c|c|c|c|}
\hline \multirow[b]{2}{*}{$\begin{array}{l}\text { Insticutional Grievance } \\
\text { Educat Lonal Pollicies }\end{array}$} & \multicolumn{7}{|c|}{ Frequency } & \multirow[b]{2}{*}{$\begin{array}{l}\text { Total } \\
\text { Respondents }\end{array}$} \\
\hline & $\begin{array}{l}\text { Strongly } \\
\text { Agree } \\
N \quad(\%)\end{array}$ & $\underline{N}$ & $\begin{array}{l}\mathrm{Bres} \\
(\%)\end{array}$ & & $\begin{array}{l}\text { Jnde- } \\
=(\%)\end{array}$ & $\begin{array}{l}\text { Dis- } \\
\text { agree } \\
\mathrm{N}^{(z)}(z)\end{array}$ & $\begin{array}{l}\text { Strongly } \\
\text { plsagree } \\
\underline{N} \text { (\%) }\end{array}$ & \\
\hline 37. Acadeinic Standarda & $1(0.2 \%)$ & 22 & $(4.6 \%)$ & 88 & $(18.5 \%)$ & $244(51.37)$ & $121(25.4 \%)$ & 476 \\
\hline 38. Curriculum Content & $3(0.6 \%)$ & 39 & $(8.3 \%)$ & 84 & $(17.7 \%)$ & $226(47.6 \%)$ & $123(25.97)$. & 475 \\
\hline 39. Degree Requirements & $1(0.2 \%)$ & 34 & $(7.2 \%)$ & 91 & $(19.7 \%)$ & $229(48.2 \%)$ & $120(25.3 \%)$ & 475 \\
\hline 40. Grading Standarda & $1(0.2 \%)$ & 26 & $(5.5 \%)$ & 94 & $(19.8 \%)$ & $228(48.0 \%)$ & $126(26.5 \%)$ & 475 \\
\hline $\begin{array}{l}\text { 41. Standards for Student Conduct and } \\
\text { Discipline }\end{array}$ & $1(0.2 \%)$ & 24 & $(5.0 \%)$ & 102 & $(21.4 \%)$ & $229(48.1 \%)$ & $120(25.2 \%)$ & 476 \\
\hline 42. Types of Degrees offered & $1(0.2 z)$ & 26 & $(5.57)$ & 87 & $(18.4 \%)$ & $229(48.47)$ & $130(27.5 \%)$ & 473 \\
\hline 43. Eat abil shment of Educational Programs & $3(0.6 \%)$ & 33 & $(7.0 \%)$ & 105 & $(22.2 \%)$ & $215(45.4 \%)$ & $118(24.9 \%)$ & 474 \\
\hline
\end{tabular}


TABLE XXXV

FACULTY RESPONDENTS. PERCEPTIONS OF COLLECTIVE

HOLC'S IMPACT ON ACADEMIC AND PERSONNEL

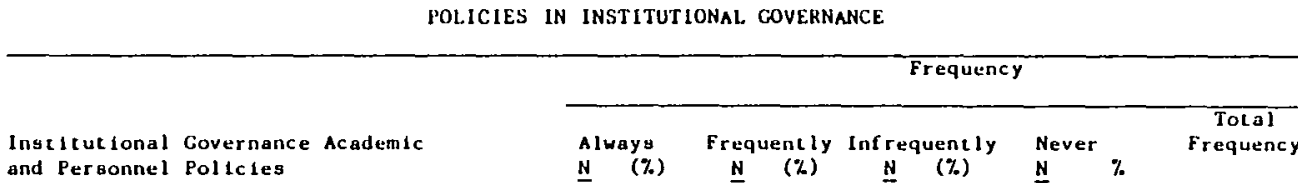

and Personnel Poltcies

$\underline{N}(\%) \quad \underline{N} \quad(\%) \stackrel{N}{N}(\%) \quad \underline{N}$

Academic Dut les

44. Teaching Asaignment

45. Teaching Schedules

46. Teaching Losde
$41 \quad(9.2 \%) \quad 80(18.0 \%) \quad 132(29.7 \%) \quad 191(43.0 \%) \quad 444$

$34 .(7.7 \%) \quad 83(18.7 \%) \quad 127(28.6 \%) \quad 200(45.1 \%) \quad 444$

$29(6.6 \%) \quad 76(17.2 \%) \quad 151(34.1 \%) \quad 187(42.2 \%) \quad 443$

Academic Standarda/Practices Pulicles for

47. Faculty Recruit tment

$31(7.17) \quad 78(17.8 \%) \quad 148(33.7 \%) \quad 182(41.5 \%) \quad 439$

48. Faculty Promotion

55 (12.47) $135(30.5 \%) \quad 133(20.0 \%) \quad 120(27.17) \quad 443$

49. Faculty Tenure

$65(14.5 \%) 137(30.5 \%) \quad 133(29.6 \%) \quad 11 \%(25.4 \%) \quad 449$

50. Academic Freedora

*51. DLsirisal for Caure

52. Salary Scale

53. Fringe Benefite

$\star 54$. Grievance Procedures

$64(14.5 \%) 144(32.5 \%) 123(27.8 \%) \quad 112(25.3 \%) \quad 443$

$74(17.0 \%) \quad 155(35.6 \%) \quad 123(28.27) \quad 84(19.3 \%) \quad 436$

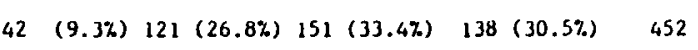

$\begin{array}{lllllllll}49(11.07) & 135(30.2 \%) & 152(34.0 \%) & 111 & (24.8 \%) & 447\end{array}$

$125(27.8 \%) \quad 180(40.0 \%) \quad 95(21.1 \%) \quad 50(11.1 \%) \quad 450$

Support Services
55. Office Space
12 (2.77) $32 \quad(7.2 \%) \quad 127(28.77) \quad 271 \quad.(61.3 \%) \quad 442$
56. Secretarial Help
$10 \quad(2.3 \%) \quad 29 \quad(6.6 \%) \quad 127(28.7 \%) \quad 276(62.4 \%) \quad 442$ 
bargaining as a supplemental governance mode in the respondents' university system has not affected the faculty's opportunity to participate in the academic issues related to teaching: (1) assignment, (2) schedule, and (3) load. As respondents' comments suggest: (1) "Our collective bargaining has done very little that was not already being done. I believe that I have input into many academic and administrative decisions, but I had this without collective bargaining;" (2) "We had all of these prior to collective bargaining in my department;" (3) "These do not relate to collective bargaining on our campus, in my opinion;" and (4) "We do all of these, but not because of collective bargaining."

Academic standards and personnel policy issues were investigated by items $47,48,49,50,51,52,53$, and 54 (See Table XXXV). From the faculty respondents' perceptions, the implementation of collective bargaining has provided the opportunity for faculty to make policy decisions related to the issues of: (1) dismissal for cause, and (2) grievance procedures. However, respondents do not tend to perceive collective bargaining as providing the faculty members with an opportunity to determine departmental personnel policies related to "support or secretarial services."

\section{Data Analysis Specific to The}

Four Dependent Variable Subsets

This section of Chapter IV was developed to present an analysis of the interaction(s) between select demographic data from Part I - 
Respondent Information and data specific to the four dependent variable sets of the study: (1) professional interests, (2) economic interests, (3) educational policies, and (4) academic/personnel policies.

Sum Scores for the Dependent Variable Sets

From the survey data, the population values for the sum scores specific for the various sections of the research instrument are shown in Table XXXVI. This statistical information allows the investigator to characterize the respondents' total responses to each of the summed dependent variables. Furthermore the Cronbach's Alpha, a measure of internal consistency, was computed for four sections of the questionnaire. Coefficients at $.90, .89, .96$, and .93 were obtained for the sections on professional interests, economic interests, educational policies and academic/personnel policies. The high alpha values obtained indicated indfviduals tended to answer questions within each section consistently and supported the use of summed scores in subsequent analysis.

TABLE XXXVI

POPULATION VALUES FOR THE SUM SCORE

\begin{tabular}{lccccccc}
\hline \multicolumn{1}{c}{ Variable } & $\mathrm{N}$ & Mean & StDev & $(.95 \mathrm{CI})$ & median & $\min$ & $\max$ \\
\hline Profegsional Interest Igsues & 458 & 3.45 & .882 & $(3.367,3.532)$ & 3.50 & 1.13 & 5.00 \\
Economic Interest Igsues & 459 & 3.36 & .812 & $(3.284,3.436)$ & 3.44 & 1.00 & 5.00 \\
Educational Policy Issueg & 469 & 3.94 & .764 & $(3.869,4.011)$ & 4.00 & 2.00 & 5.00 \\
Academic/Personnel Interest Igsues & 410 & 2.31 & .741 & $(2.737,2.883)$ & 2.82 & 1.00 & 4.00 \\
\hline
\end{tabular}

The total respondents' sum-scores (see Table XXVII) for the two 
dependent variable sets, professional and economic interests, can be characterized as undecided/disagree. The respondents are best described as in disagreement with the dependent variable concerned with educational policies. The fourth dependent variable of the study, academic/personnel policies, is characterized by the data as infrequent.

TABLE XXXVII

CHARACTERISTICS FOR THE DEPENDENT VARLABLE SUB-SETS ACCORDINC TO SUM-SCORES

\begin{tabular}{lccl}
\hline $\begin{array}{l}\text { Dependent } \\
\text { Varlable Sub-Set }\end{array}$ & Questions & $\begin{array}{l}\text { Median } \\
\text { Sum-Score }\end{array}$ & $\begin{array}{l}\text { Characteristics } \\
\text { of Responses }\end{array}$ \\
\hline Profegsional Interegts & $20-27$ & 3.50 & Undecided/Disagree \\
Economic Interests & $28-36$ & 3.44 & Undecided/Dtsagree \\
Educational Policies & $37-43$ & 4.00 & Disagree \\
Academic/Personnel Policies & $44-56$ & 2.82 & Infrequencly \\
\hline
\end{tabular}

These sum variables, (1) professional interests, (2) economic interests, (3) educational policies, and (4) academic/ personnel policies form the four hypotheses. Therefore, the sum-scores for each variable were further examined to statistically answer the research question, "Has the adoption of collective bargaining as a supplemental governance mode by three of Oregon's 4-year institutions of higher education been supportive of the faculty members' rights for participation in institutional governance?"

Hypothesis Testing

In order to answer the research question, the four hypotheses of 
the study were tested. The sum scores for the dependent variable set were studied using nine independent variables: (1) the number of teaching years in a 4-year institution of higher education, (2) AAUP membership, (3) salary, (4) governance, (5) age, (6) involvement in the institution's bargaining process, (7) academic rank, (8) institution of employment, and (9) departmental assignment. More precisely, the Kruskal-Wallis one-way analysis of variance test was used to identify those sub-groups of the respondents whose answers generated significantly different sum scores.

Two of the independent variables, academic rank and the number of full-time teaching years in a 4-year institution of higher education, generated no significant statistical differences for any of the sum variables. However, seven of the nine independent variables tested, (see Table XXXVIII) at the 0.05 level, generated a statistically significant difference for the summed dependent variables.

TABLE XXXVIII

\begin{tabular}{|c|c|c|c|c|}
\hline \multirow[b]{2}{*}{$\begin{array}{l}\text { Independent } \\
\text { Variables }\end{array}$} & \multicolumn{4}{|c|}{ Summed Dependent Variable Set } \\
\hline & $\begin{array}{c}\text { Professional } \\
\text { Interests } \\
(\mathrm{H}: \mathrm{l})\end{array}$ & $\begin{array}{c}\text { Economic } \\
\text { Interests } \\
(H: 2)\end{array}$ & $\begin{array}{l}\text { Educational } \\
\text { Policies } \\
(\mathrm{H}: 3)\end{array}$ & $\begin{array}{c}\text { Academic/Personnel } \\
\text { Polictes } \\
(\mathrm{H}: 4)\end{array}$ \\
\hline AAUP Membership & .0001 & .0001 & NS & NS \\
\hline Salary & .0001 & .0002 & .0004 & .0008 \\
\hline Governance Bodies & NS & NS & .005 & NS \\
\hline Age & NS & NS & NS & .03 \\
\hline $\begin{array}{l}\text { Institutional In- } \\
\text { volvement With } \\
\text { Bergaining }\end{array}$ & .0001 & .0001 & .003 & .0001 \\
\hline Institution & .005 & .007 & NS & .0002 \\
\hline Department & NS & .03 & .03 & NS \\
\hline
\end{tabular}


Hypothesis One $(H: 1)$

To further explore $H: 1$, the collective bargaining process has affirmed the professional interests of the academician with an appointment in Oregon's 4-year institutions of higher education, subgroup means were computed.

As a result of the one-way analysis of variance testing, no significant statistical differences were found between the independent variables, age, governance comnittee membership, or departmental assignment and the sum data for the dependent variable, professional interests. However, as illustrated in Table $\mathrm{XXXIX}$, the sum variables and the demographic variables, AAUP membership, employing institution, salary and involvement in bargaining, exhibited statistically

significant differences.

TABLS $\cos x$

\begin{tabular}{|c|c|c|c|}
\hline \multirow{2}{*}{\multicolumn{2}{|c|}{ Indepandent Varlabled }} & \multicolumn{2}{|c|}{ Profestonel Intereste } \\
\hline & & $n$ & Arerage Seorne \\
\hline \multicolumn{4}{|c|}{ (1) MUP Kemberohip } \\
\hline & $\begin{array}{l}\text { (a) } Y_{10} \\
\text { (b) Mo }\end{array}$ & $\begin{array}{l}136 \\
303\end{array}$ & $\begin{array}{l}3.21= \\
3.55=\end{array}$ \\
\hline \multirow[t]{2}{*}{ (2) $\mathrm{c}$} & Enploying Inutitulion & & \\
\hline & 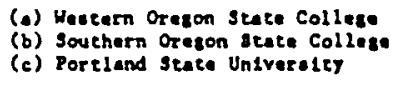 & $\begin{array}{r}73 \\
93 \\
292\end{array}$ & $\begin{array}{l}3.13+4 \\
3.43+ \\
3.33+4\end{array}$ \\
\hline \multirow[t]{2}{*}{ (3) 5} & Salery for 9 s. Concrace & & \\
\hline & $\begin{array}{l}\text { (a) } \$ 10,000-\$ 23,000 \\
\text { (b) } \$ 26,000-\$ 30,000 \\
\text { (c) Ovar } \$ 30,000\end{array}$ & $\begin{array}{l}160 \\
162 \\
132\end{array}$ & $\begin{array}{l}3.23 \% \\
3.39 \% \\
3.70 \%,+\end{array}$ \\
\hline \multirow[t]{2}{*}{ (4) } & Involveoent in argalnine & & \\
\hline & $\begin{array}{l}\text { (a) No Involveount } \\
\text { (b) silehely Active } \\
\text { (c) Active } \\
\text { (d) Vary Active }\end{array}$ & $\begin{array}{r}284 \\
106 \\
40 \\
27\end{array}$ & $\begin{array}{l}3.67 * \\
3.20 *, 4 \\
3.01 * \\
2.69 *, 4\end{array}$ \\
\hline
\end{tabular}


As previously indicated, the respondents' answers related to the sum variable, professional interests, were clearly skewed to the right side of the research instrument's 5-point Likert Scale, used by the faculty members to record their responses to each question:

(1) AAUP Membership - The respondents who are nembers of the American Association of University Professors (AAUP) appear to be rather undecided about whether or not academic collective bargaining has provided support for their professional interests, whereas the respondents who are not members of the AAUP seem closer to disagreement that collective bargaining has provided such support. Although the AAUP nonmembers' mean score is 3.55 , their responses are significantly closer to the "disagree" category on the 5-point Likert scale, Wilcoxon $z=$ $3.88, \mathrm{p}=.0001$

(2) Employing Institution - The average scores range from 3.13 to 3.53 for the respondents employed by the three subject unionized institutions. These respondents reported scores are between the "undecided" and "disagree" categories on the Likert scale. Respondents employed by Western Oregon State College appear statistically to be more undectded about the effects of the bargaining process in providing for their professional interests than is the faculty group from Southern Oregon State College and Portland State University. These latter groups' perception of the process, as the mean score shows, is statistically closer to disagreeing that the process has provided for their professional interests within the employing university system. 
(3) Salary - The mean scores for faculty respondents who have a salary within the $\$ 10,000-\$ 25,000$ range, as well as the $\$ 26,000-$ $\$ 30,000$ salary range, suggest that these groups lean significantly more toward being "undecided" about the association between the collective bargaining process and their professional interest rights as an academician, than does the group reporting salaries over $\$ 30,000$ for a 9 month academic year ( $\mathrm{Q} 3.3, \mathrm{p}<0.005$, Table B.14 in Zar, p. 568).

(4) Involvement In The Process - Faculty members reporting no involvement in the collective bargaining process perceptions are significantly closer to "disagreeing" that the process has been a facilitator of their professional interests in the employing university setting, than do respondents reporting involvement in the process.

Hypothes is Two ( $\mathrm{H}: 2$ )

To further study if the collective bargaining as implemented in Oregon's 4-year institutions of higher education has provided for the academicians' participation in the planning and policy-making process related to the economic interests of the institution, simultaneous comparisons of sub-group means were computed using the previously stated nine independent variable and the sum-variable economic interests. As a result of the additional testing, a statistically significant relationship was identified (See Table XL) between the faculty respondents' perceptions of academic collective bargaining as providing for the institution's economic interests and five of the demographic variables: (1) departmental appointment, (2) AAUP membership, 
(3) employing institution, (4) involvement in the institutional

bargaining process, and (5) salary. No statistical association was

shown between this sum-variable and the independent variables of age and membership in university or departmental governance committees.

TABLE XL

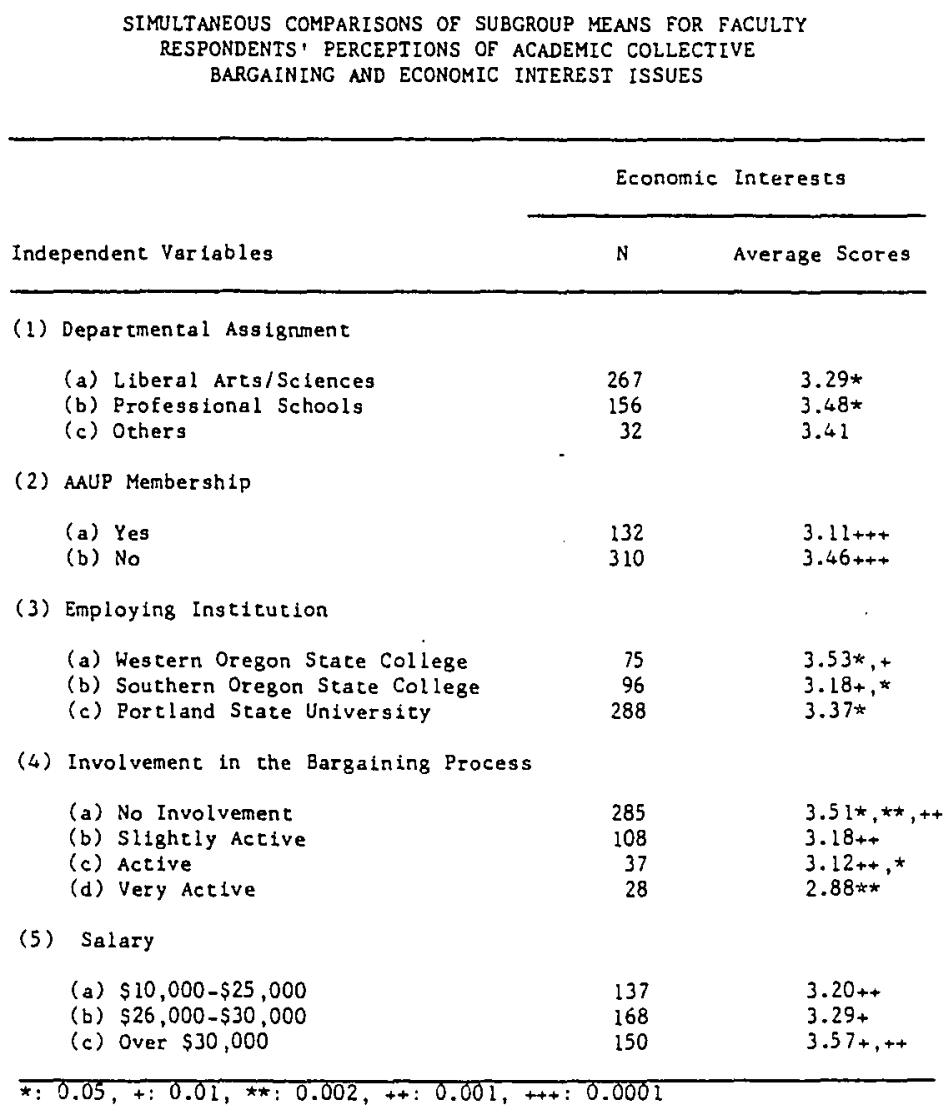

(1) Departmental Appointment - A statistically significant difference was found at the $p<0.05$ level between the departmental appointments of the Liberal Arts/Sciences and the Professional Schools 
relative to the dependent variable "economic interests." Respondents with an appointment in a professional school disagree more about academic collective bargaining as a supplemental mode that has provided for the participation in these processes related to the institution's economic interests. While respondents in the third departmental sub-group "others" had no significant statistical relationship identified, their mean score of 3.41 , like the other departmental groups, fell between the "undecided" and "disagree" categories on the Likert Scale.

(2) AAUP Membership - For both the respondent groups selecting/not selecting membership in the (AAUP) American Association of University Professors, a statistically significant assessment was found at the .0001 level. Although faculty members with membership seem to be "undecided" about the role that the bargaining process has provided for the nonmembers' participation in the institution's "economic interests," their mean-score of 3.55 is closer to the "disagree" category on the scale Wilcoxon $\mathrm{Z}=4.20, \mathrm{p}<.0001$.

(3) Employing Institution - Faculty respondents at all three institutions seem to lie on the "disagree" side of the "undecided" category about academic collective bargaining as a supplemental governance mode that has provided for the participation in those processes specific to "economic interests." The findings indicate that the respondents from Western Oregon State College and Portland State University lean more toward the "disagree" category on the scale than do the respondents employed at Southern Oregon State College. 
(4) Involvement in Bargaining - The "no involvement" respondents appear to perceive the process in relationship to their participation in the issues related to the institution's "economic interests" nearer to the "disagree" category on the 5-point scale, with a mean score of 3.51 , than do respondents indicating very active involvement.

(5) Salary - All three groups of faculty respondents, according to their salary range for the academic year, are "undecided" to "disagree" about the collective bargaining process as a facilitator for the "economic interests" of their university system. The respondents with an academic year income over $\$ 30,000$ are significantly closer to the "disagree" category than the two groups of respondents earning less for an academic year appointment.

Hypothes is Three $(\mathrm{H}: 3)$

As reported earlier in the chapter, the frequency distribution of the respondent answers to questions $37-43$ of the research instrument seems to indicate faculty members "disagree" that collective bargaining has been necessary to provide for the opportunity to determine educational policies related to seven academic issues: (1) academic standards, (2) curricular content, (3) degree requirements, (4) grading standards, (5) standards for student conduct/discipline, (6) type of degrees offered, and (7) the establishment of educational programs. This position is further supported by the reported respondents: comments.

However, from the statistical information provided by the analysis 
of subgroup means, (See Table XII) a significant difference can be reported between the educators' perception of academic collective bargaining as providing an opportunity to determine institutional educational policy and the respondents' (1) membership on a university/departmental governance committee, (2) departmental assignment, (3) salary, and (4) amount of involvement with the bargaining process.

TABLE XII

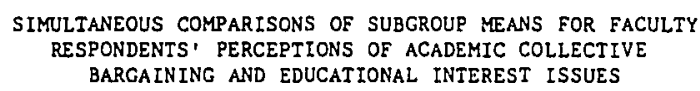

\begin{tabular}{lll}
\hline & \multicolumn{2}{c}{ Educational Interests } \\
\cline { 2 - 3 } Independent Variables & $\mathrm{N}$ & Average Scores \\
\hline
\end{tabular}

(1) Governance Bodles

$\begin{array}{lll}\text { (a) Faculty Academic Senate } & 74 & 4.09 \star * \\ \text { (b) Flnance } & 12 & 4.12 \\ \text { (c) Rank \& Tenure } & 64 & 3.68 \star \star \\ \text { (d) Others } & 99 & 3.93\end{array}$

(2) Departmental Asaigrment

$\begin{array}{lcl}\text { (a) Liberal Arts/Sciences } & 278 & 3.90 * \\ \text { (b) Professional Schools } & 156 & 3.96 \\ \text { (c) Others } & 31 & 4.21 *\end{array}$

(3) Salary
(a) $\$ 10,000-\$ 25,000$
(b) $\$ 26,000-\$ 30,000$
(c) Over $\$ 30,000$

$\begin{array}{ll}141 & 3.80++ \\ 168 & 3.88+ \\ 157 & 4.12+,++\end{array}$

(4) Involvement in the Bargaining Process
(a) No Involvement
(b) Slightly Active
(c) Active
(d) Very Active

$\begin{array}{rl}289 & 4.04+ \\ 110 & 3.77+ \\ 41 & 3.70 \\ 28 & 3.90\end{array}$

Note: $*: 0.05 ;+: .02 ; \star \star: 0.05,++: 0.001$

(1) Membership on Governance Committee - as shown in Table XLI, significant difference at the $\mathrm{p}<.005$ level was found between those 
respondents reporting membership in the Faculty Academic Senate and the Rank and Tenure Committee. While the respondents who hold membership on a Faculty Academic Senate appear to disagree that bargaining has provided them with the opportunity to participate in the institution's educational policy decisions, members of Rank and Tenure Committee scores lie significantly closer to the "undecided" category on the Likert Scale $(Q=3.38)$.

(2) Departmental Assignment - In the subject institutions, faculty respondents with an appointment in a Liberal Arts/Sciences department disagreed less about the bargaining process as a positive factor in providing for their opportunity to determine educational policy than those faculty members with appointments in "other" departments in the university system.

(3) Involvement With Bargaining - A statistical significance of $p<.02$ was found between the sum variable, educational policies, and the two classifications of slightly active and no involvement that faculty members can select for their involvement in the institution's collective bargaining process. The respondents reporting a "no involvement" on the Likert Scale produced a mean score indicating more disagreement than their colleagues indicating some degree of involvement in the institution collective bargaining process. This difference was significant only for the "slightly active" group $(Q=3.09)$.

(4) Salary - The respondents reporting their academic year salaries between $\$ 10,000$ - $\$ 30,000$ statistically appear to disagree somewhat (but significantly) less about the opportunities that the bargaining process 
has provided for determining the institution's educational policies, than the over $\$ 30,000$ group.

Hypothesis Four $(\mathrm{H}: 4)$

To further explore H:4, collective bargaining has provided the faculty members in Oregon's 4-year institutions of higher education with the opportunity to participate in determining the academic and personnel policies of their employment, differences in subgroup sum score means were analyzed.

As illustrated in Table XLII, significant statistical differences were identified within the independent variables of respondents' (1) age, (2) employing institution, (3) involvement in bargaining, and (4) salary.

(1) Age - The 60 and over respondents appear to perceive a statistically significant less frequent opportunity to determine the academic/personnel policies of their employment than do those aged 40-49 years. The other age groups ( $30-39$ years, $50-59$ years) fall in between these groups and do not statistically differ from either of the extremes. Overall, though, even the respondents in the $40-49$ year age range lean more to the "infrequently" category than to the "frequently" option.

(2) Employing Institution - Faculty respondents' perceptions of academic collective bargaining as a process to provide for them the opportunity to determine academic policies on the average lie between "frequently" and "infrequently" and somewhat closer to the latter 
characterization. A statistically significant difference was identified

TABLE XLII

SIMULTANEOUS COMPARISONS OF SUBGROUP MEANS FOR FACULTY

RESPONDENTS' PERCEPTIONS OF ACADEMIC COLLECTIVE BAR GAINING AND ACADEMIC/PERSONNEL INTERESI ISSUES

\begin{tabular}{c} 
Academic/Personnel Interests \\
\cline { 2 - 3 } Independent Variables
\end{tabular}

(1) Age
(a) $30-39$ years
(b) $40-49$ years
(c) $50-50$ years
(d) 60-over

$\begin{array}{rl}27 & 2.78 \\ 156 & 2.70 \star \\ 169 & 2.84 \\ 58 & 3.02 \star\end{array}$

(2) Employing Institution
(a) Hestern Oregon State College
(b) Southern Oregon State College

$\begin{array}{rl}68 & 2.49++ \\ 87 & 2.74 \\ 225 & 2.92+++\end{array}$
(c) Portland State University
2.74

(3) Involvement in the Bargalning Process
(a) No Involvement
(b) Slightly Active
(c) Active

$\begin{array}{rl}289 & 3.00 \star \star,++ \\ 110 & 2.65 \star \star \\ 41 & 2.34++ \\ 28 & 2.22++\end{array}$

(4) Salary
(a) $\$ 10,000-\$ 25,000$
(b) $\$ 26,000-\$ 30,000$
(c) Over $\$ 30,000$

$\begin{array}{ll}121 & 2.63++ \\ 147 & 2.80 \\ 139 & 2.97++\end{array}$

Note: *: $.005 ; \star \star 0.002 ;++0.001$

at the $\mathrm{p}<.001$ level for two of the subject institutions, Western

Oregon State College and Portland State University, and the sum variable, academic/personnel policies. While Portland State University respondents lean closer to the "infrequently" category of the scale with a mean-score of 2.92 , (vs. 3.00 for "infrequently") those respondents from Western Oregon State College lie almost exactly midway between the "frequent" and the "Infrequent" categories with a mean-score of 2.49 . No statistically significant difference was found for the Southern 
Oregon State College respondents. However, their mean-score of 2.74 , like that of Portland State University respondents, is closer to the "Infrequent" category.

(3) Involvement In Bargaining - Statistically significant differences were identified between the amounts of involvement that faculty respondents select to have in their institution's bargaining process. While there was no significant difference between groups indicating at least "slight activity," increased levels of activity corresponded to increasing perceptions of "frequent" opportunities to determine the academic/personnel policies of their employment (see Table XLII). For the respondents selecting "no involvement" in the process, however, the process is perceived as "infrequently" providing those faculty members employed in their institutions with the opportunity to determine academic/personnel policies. The difference between this level of inactivity and all the other levels of activity ("slight to very") is statistically significant $(\mathrm{p}<.002)$.

(4) Salary - A significant statistical finding at the $p<.001$ level (See Table XIII) was identified between the two extreme levels of respondents' salary range. Those respondents in the salary range of over $\$ 30,000$ seem to perceive that the process has more "infrequently" assisted them with the opportunity to determine policy than their colleagues with salaries between $\$ 10,000-\$ 25,000$. However, their mean-scores are toward the "infrequent" category on the scale. While no significant difference was found for the respondents receiving an academic salary of $\$ 26,000-\$ 30,000$, their mean-score of 2.80 , like 
those of the other two groups, is closer to the "Infrequent" category of the 4-point scale. 


\section{Chapter V}

Summary, Conclusions and Recommendations

Chapter $V$ presents a brief summary of the study, the conclusions suggested from the results of the findings, and recommendations for further research.

\section{Summary of the Study}

In the 1960s, the contemporary American university system emerged as a powerful societal force, with economic and political influences, as well as concentrated resources and a multipurpose capacity (Kerr, 1963). During this period, faculty members were committed to the concept of shared authority as the governance mode for the higher education enterprise. However, it was a brief golden age for the traditional academic governance mode (Garbarino, 1975).

The mid-1960s brought a combination of external and internal contextual factors to the university system, which impacted upon the governance structure and function of the academy (Garbarino, 1975). In 1966, one consequence of these events was the entry of collective bargaining into the university system. It was a process that was not intended as an alternative to the traditional governance mode of the academy, but rather a supplemental mode to support the advancement of faculty governance rights (Polishook, 1982).

A dynamic social process grounded in the labor movement dating from the industrial revolution, academic collective bargaining, amid hostile 
concerns and myths, has made enormous gains as a supplemental governance mode in the 4-year private and public institutions of higher education (Polishook, 1982). It is a growth that has been assured by a well-defined legal environment, which has established laws as the basis for federal and state sector employee negotiations (Hedgepeth, 1974). Academic collective bargaining, as the mode of governance adopted by academicians to impose or reinstate independence into their professional lives, has been confirmed by the scholarly works of such educational analysts as Aussieker, Garbarino, Baldridge and Lee (Schulman, 1979). As Barbara A. Lee wrote in 1979:

Faculty as a whole gained formal governance powers through the union contract. Even on campuses where faculty have enjoyed considerable decision-making puwer, the contract legitimized and in many cases broadened the scope of faculty governance rights (Lee, 1979). Therefore, the research question arises: Has the adoption of collective bargaining as a supplemental governance mode by three of Oregon's 4-year institutions of higher education supported faculty members' rights for participation in institutional governance?

The purpose of this survey was to study select faculty members with an academic appointment in Oregon's 4-year unionized institutions of higher education to evaluate whether or not they perceive the process of collective bargaining as supportive of faculty members' rights to participate in institutional governance. To achieve the stated purpose, the following problems were investigated: 
1. Have the professional interests of those academicians with an appointment in Oregon's 4-year institutions of higher education been affirmed through the collective bargaining process?

2. Has collective bargaining provided for the academicians' participation in financial planning and policy-making related to their economic interests as employees of an Oregon 4-year institution of higher education?

3. Do faculty members with an academic appointment in Oregon's 4-year unionized institutions of higher education participate in determining those institutional educational policies related to academic issues?

4. Has the collective bargaining process provided the faculty members in Oregon's 4-year institutions of higher education with the opportunity to participate in determining the academic and personnel policies of their employment?

The population of the study consisted of 694 faculty members holding an academic appointment in one of Oregon's 4-year unionized institutions during the spring of 1984. Those faculty members selected for the study must (1) have held a full-time faculty appointment during the academic year, (2) have been employed in the present institution for a minimum of five years, and (3) have or be on a tenure track appointment in the department.

Data for the study were collected from the population using a 56 item research instrument entitled "A Questionnaire to Study Collective Bargaining as a Process Adopted in Oregon's 4-Year Institutions of 
Higher Education to Provide for Faculty Members' Participation in Institutional Governance," in three major areas: (1) Respondent Information, (2) Institutional Information, and (3) Institutional Governance Information.

\section{Conclusions of the Study}

Respondent Information

From the findings of the study, the results suggest that of those respondents holding an appointment in an Oregon 4-year unionized institution during the 1983-84 academic year: (1) the largest sub-group have taught in a 4-year institution of higher education between 16 and 20 years; (2) the majority do not hold membership in the American Association of University Professors (AAUP); (3) a large number elect to have no involvement in their institution's collective bargaining process; (4) the greatest percentage were in the 40-49 year age range at Southern Oregon College and Portland State University, while the greatest number at Western Oregon State College reported their ages in the 50-59 range; and (5) the salary range of $\$ 26,000-\$ 30,000$ was reported by the majority at Southern Oregon State College and Portland State University, with a majority reporting a salary in the $\$ 21,000-\$ 25,000$ range at Western Oregon State College.

Institutional Influences

The research data suggest that contextual factors influenced respondents in all three subject institutions to vote for a contract renewal in 1983. Those contextual factors included (1) funding, 
(2) decision making processes/bodies, and (3) organizational changes.

1. Funding -- At all three institutions, respondents reported reduced funding specific to: (a) state legislative funds, and (b) Instructional funding required for the development of academic programs was perceived as a significant factor in their decision to vote.

(2) Decision-Making -- Processes and decision making bodies related to the development of institutional educational policy at the state and departmental level of governance were identified as significant contextual factors to respondents at Portland State University and Southern Oregon State College. Furthermore, the data suggest faculty respondents at Portland State University and Western Oregon State College perceived a decline in their participation in policy-making decisions at a departmental level as a significant factor in their collective bargaining vote.

(3) Organizational Changes -- Two organizational changes: (a) a new mission and goal statement, and (b) a new organizational structure were perceived by Western Oregon State College respondents as a significant factor in their decision to vote for the renewal of the institutional bargaining contract.

Hypotheses of the Study

For this study, it was hypothesized that collective bargaining would support the rights of faculty members with academic appointments 
in Oregon's 4-year institutions of higher education to participate in institutional governance.

The research instrument, "A Questionnaire to Study Collective Bargaining As a Process Adopted In Oregon's 4-Year Institutions of Higher Education to Provide for Faculty Members' Participation in Institutional Governance," was used to measure the faculty members' perception of collective bargaining as a supplemental governance mode in their university system, specific to four dependent variables: (1) professional interests, (2) economic interests, (3) educational policies, and (4) academic/personnel policies.

The Kruskal-Wallis one-way analysis of variance test was used to test each of the four hypotheses of the study:

H:1 The collective bargaining process has affirmed the professional interests of the academician with an appointment in Oregon's 4-year institutions of higher education.

H:2 Collective bargaining, as implemented in Oregon's 4-year institutions of higher education, has provided for the academicians' participation in the planning and policy-making process related to the economic interests of the institution.

H:3 Faculty members with an academic appointment in Oregon's 4-year unionized institutions of higher education participate in determining the institution's educational policy on academic issues.

$\mathrm{H}: 4$ Collective bargaining has provided the faculty members in Oregon's 4-year institutions of higher education with the 
opportunity to participate in determining the academic and personnel policies of their employment.

Although statistically significant differences were found within each dependent variable subset of data, the four hypotheses of the study as stated are rejected. However, the results of the study suggest the following general conclusions specific to each of the data subsets.

\section{Professional Interests}

Respondents in the three subject institutions did not appear to perceive academic collective bargaining as supportive of their "professional interests." However, the data suggest respondents in all three subject institutions tend to agree the collective bargaining process has provided them with "a formalized structure and process for institutional decision-making." This is a very important result of academic collective bargaining, as identified by the scholarly works of Lee, 1979, Nelson, 1982, and Baldrj.dge, 1982.

\section{Economic Interests}

The aggregate data suggest that the greater number of respondents do not agree that academic collective bargaining has provided for their participation in the planning and policy-making process related to the institution's economic interests. This perception is quite different, however, when viewed from the respondents' data as related to specific subject institutions. These findings lend this investigator to conclude :

(a) The collective bargaining process is viewed by the majority of 
respondents at Western Oregon State College as having provided an "increase in the importance of the budgetary/financial affairs committee's role in university budget analysis and planning;"

(b) A substantial number of respondents at Portland State University appear to perceive that the bargaining process has "clarified the problem of a low faculty salary schedule in Oregon's system of higher education" for their institution; and (c) Academic collective bargaining, according to the survey data, is perceived by the Southern Oregon State College respondents as a supplemental governance mode that has facilitated the issue of institutional "economic interests." Data from these respondents suggest that the process has: (1) clarified the low salary schedules for those faculty respondents in Oregon's system of higher education, (2) increased the importance of the budgetary/financial affairs committee's roles in their university budget analysis and planning, and ( 3 ) strengthened their input into short-range planning. These respondents also identified the process as having: (1) assisted the faculty and administration to present a united agreement to the state legislature and, more importantly, (2) increased their salary and fringe benefits.

\section{Educational Policies}

Respondents at the three subject institutions do not agree that 
academic collective bargaining has been/is necessary to provide for their rights as a faculty member to determine institutional educational policies for the academic issues of: (1) teaching, (2) programs, or (3) students.

Moreover, the respondents of these institutions suggest that these rights have been provided by either administrative rules or a faculty constitution prior to the adoption of collective bargaining.

Academic And Personnel Policies

While the data indicate that collective bargaining has not provided the faculty members with opportunities to determine the policies related to the academic duties or standards of teaching (1) assignments, (2) schedules, or (3) loads, the process has provided the faculty with the opportunity to make policy decisions for the two important issues of (1) dismissal for cause, and (2) grievance procedures. For the Oregon academicians, this is an important result of the bargaining process, as Barbara Lee in 1979 concluded from her study: "The single most significant effort of unionization was the promulgation of a formal grievance procedure" (Lee, 1979).

\section{Recommendations}

\section{Suggested Further Research}

Since the 1969 Carnegie Commission on Higher Education report was published, educational analysts have researched the multidimensional complexities of academic collective bargaining. From these studies, 
scholars have confirmed the causes, effects, as well as the major trends of the process, as adopted by the university system (Lee, 1979;

Baldridge, 1982).

This investigator, like other educational scholars, is convinced that additional research must be conducted in order to empirically test those collective bargaining issues in academia that are still only reasonable hypotheses (Spinard, 1984). Therefore, the following academic bargaining issues specific to (1) the Oregon system of higher education; and (2) an expanded academic population are suggested for future research.

\section{Oregon System of Higher Education}

Within the 4-year institutions of Oregon's higher educational system, the following research appears to be warranted.

First, research could be conducted to evaluate the perception of those fauclty members employed in the three subject institutions who (1) have taught less than five years in a university system, (2) lack tenure, and/or (3) hold a lower academic rank. The perceptions of this faculty population about institutional governance night show a considerable difference from that of the respondents of this study. As the early research of Ladd and Lipset found:

Faculty employed in the lower tier of academia -- in terms of scholarly benefits, financial resources, and economic benefits -- and those who are in the lower ranks, lack tenure, and who are younger are much more likely to favor organized collective 
action (Ladd and Lipset, 1973).

Second, the aggregate data of the study showed the greater number of respondents in the three subject institutions elect nonparticipation in the institutional bargaining process. However, this study found statistically significant differences between the degree of the respondents' involvement in the process and their perceptions of academic collective bargaining as a supplemental governance mode. Therefore, a question for further research could be, "If academic collective bargaining has been selected by the faculty members as a supplemental governance mode for the institution, why do they not elect to be an active participant in the process?"

Third, a major trend of academic collective bargaining has been to serve the economic concerns of the faculty. In addition, it should provide for faculty involvement in budgeting decisions, which are critical to assure the establishment of academic goals consistent with academic values (Mason, 1982). A study could be conducted that would compare those faculty members employed in Oregon's three unionized institutions with the faculty of the five non-unionized 4-year institutions on economic issues. More precisely, this study would focus on those issues specific to (1) salary and (2) budgetary planning of the institutions.

Fourth, this research study suggests that the Southern Oregon State College respondents appear to have a positive attitude toward academic collective bargaining as a facilitator of their rights to participate in the governance process. Southern Oregon State College respondents, 
unlike those at Western Oregon State College and Portland State University, are represented by an independent bargaining agent. Therefore, a research study could be designed to study the question, "Do respondents: attitudes toward their bargaining agent influence their perceptions of academic collective bargaining as a supplemental governance mode?"

Fifth, and of particular interest to the investigator, would be a study to identify those contextual factors, as well as the academic governance structures and relations, which influenced the faculty members at the University of Oregon and Oregon State University, in 1977 and 1983 respectively, to defeat a union coalition.

\section{An Expanded Population}

The investigator has extensively reviewed the literature in order to identify the scope of research that has been conducted on academic collective bargaining as a supplemental governance mode. This study, like many reviewed, limits the survey to a specific geographical population. Therefore, it is recommended that this study be replicated using a larger number of 4-year institutions of higher education, in order to have more generalized data about faculty members' perceptions of academic collective bargaining to answer the research questions of the study: Has the adoption of collective bargaining as a supplemental governance mode supported faculty members' rights for participation in institutional governance? 


\section{Closing Summary}

This chapter has provided a summary of the study, a discussion of the conclusions suggested from the findings of the study, specific to the three major areas of the research study: (1) respondent information, (2) institutional influences, and (3) institutional governance information. In addition, recommendations were made for further research to answer the question, Has academic collective bargaining, as a supplemental governance mode, supported faculty members' rights for participation in institutional governance?

To sum up, this investigator concurs with the statement of Ernest Benjamin, the new American Association of University Professors General Secretary, that:

Bargaining is not a substitute for governance. Rather, collective bargaining provides a foundation for the defense of governance as the tightened academic market both lessens the bargaining power of individual faculty and increases the pressure on administration to subordinate academic and external priorities. Faculty will continue to pursue -through agreement, litigation, or legislation -- the right to bargain (Benjamin, 1984). 


\section{References}

Adams, W. (1974). The state of higher education: myths and realities. AAUP Bulletin, 60, 119-125.

Alder, D. L. (1977). Governance and collective bargaining in four-year institutions, 1970-1977. Washington, DC: Academic Collective Bargaining Information Service. (ERIC Document Reproduction Service No. ED 168 370)

Allhouse, M. F. (1975). Tenure: A tradition that needs scrutiny. AGB Report, 17, 26-32.

American Psychological Association. (1983). Publication manual of the American Psychological Association. Washington, DC:

American Association of University Professors. (1984). Policy documents and reports (Ed. 1984). Washington, DC:

Armstrong, M. R. (1981). Faculty participation in governance and collective bargaining: A study of the Yeshiva model of academic governance applied to selected Florida public community colleges and universities. Dissertation Abstracts International, 42, 1020 .

Astin, A. W. (1976). Academic gamesmanship: Student-change in higher education. New York: Praeger.

Balderstron, F.E. (1974). Managing today's university. San Francisco: Jossey-Bass. 
Baldridge, J. V. (1971). Academic governance: Research on institutions, politics and decision-making. Berkeley, Calif.: McCutchan.

Baldridge, J. V. (1971). Power and conflict in the university: Research in the sociology of complex organizations. New York: John Wiley \& Sons.

Baldridge, J. V. (1982). Shared governance: A fable about the lost magic kingdom. Academe, 69, 12-14.

Baldridge, J. V. (1982). Reflections on 'dual track' governance. Academe, 8-9.

Baldridge, J. V. \& Kemerer, F. R. (1976). Academic senate and faculty collective bargaining. Journal of Higher Education, 47, $391-411$.

Batz, R. L. (1978). A critical investigation of policies and procedures pertinent to tenure and the grievance procedure, both before and after collective bargaining at public community-junior colleges. Dissertation Abstracts International, 39, 5969.

Begin, J. P. (1974). Faculty governance and collective bargaining: An early appraisal. Journal of Higher Education, 20, 582-583. Begin, J. P. (1978). Statutory definitions of the scope of negotiations: The implications for traditional faculty governance. Journal of Higher Education, 49, 247-260. Benjamin, E. (1984). Why do faculty persist in seeking collective bargaining? AAUP Collective Bargaining News letter, 8 . 
Bierstedt, R. (1964). The problem of authority. In Berger, Abe1 \& __ Page. Freedom and control in modern society. New York: Octagon.

Boyd, W. B. (1971). Collective bargaining in academe: Causes and consequences. Liberal Education, 57, 306-318.

Brown, R. C. (1977). Tenure rights in contextual and constitutional context. Journal of Law and Education, 6 , 279-316.

Brown, R. S., Jr. (1969). Collective bargaining in higher education. Michigan Law Review, 67, 1067-1082.

Burns, J. M. (1979). Two excerpts from leadership. Educational Leadership, $26,380-383$.

Clarke, C. A. (1981). The Yeshiva case: An analysis and an assessment of its potential impact on public universities. Journal of Higher Education, 52, 449-469.

Crosslord, F. E. (1976). Will the academy survive unionization. Change, $8,38-42$.

Douglas, J. M. (1984). Directory of faculty contracts and bargaining institutions of higher education (No. 10). New York: Baruch College, City University of New York, the National Center for the Study of Collective Bargaining in Higher Education and the Profession.

Davidson, J. F. (1982). Tenure, governance, and standards in the academic community. Liberal Education, 68, 35-42.

Drucker, P.F. (1973). Management: Tasks, responsibilities, practices. New York: Harper \& Row. 
Duryea, E. D., \& Fisk, R. S. (1973). Faculty unions and collective bargaining. San Francisco: Jossey-Bass.

Eble, K. E. (1978). The art of administration. San Francisco: Jossey-Bass .

Finkin, M. W. (1971). Collective bargaining and university government. AAUP Bulletin, 57, 149-162.

Finkin, M. W. (1981). Regulation by argument: The case of private higher education. Academe, 67, 67-80.

Flippo, E. (1970). Management: A behavioral approach. Boston: Allyn and Bacon.

French, W. (1974). The personnel management process: Human resource administration. Boston: Houghton Mifflin.

Garbarino, J. W. (1973). Emergence of collective bargaining. In E.D. Duryea \& R.F. Fisk (Eds.) Faculty unions and collective bargaining (pp. 1-3). San Francisco: Jossey-Bass.

Garbarino, J. W., \& Aussieker, Bill. (1975). Faculty bargaining: Change and conflict. New York: McGraw-Hill.

Garbarino, J. W. Fellers, D. E. \& Finklin, M. W. (1977). Faculty bargaining in public higher education. San Francisco: Jos sey-Bass.

Garfin, M. (1979). Collective bargaining in higher education. New York: National Center for the Study of Collective Bargaining in Higher Education. (ERIC Document Reproduction Service No. ED 172 659). 
Glidden, P. A. (1977). Academic senates. Industrial Relations Law Journal, 11, 219-243.

Gorman, R. A. (1979). Report on committee N on representation of economic and professional interests: 1978-79. Academe, 65, $410-412$.

Hagengruber, D. L. (1978). Reasons why faculty members accept or reject unions in higher education: The Wisconsin experience. Journal of Law and Education, ㄱ, 53-78.

Hall, R. (1977). Organizations: Structures and process. New Jersey: Prentice-Hall.

Haslam, C. S. (1974). The locus of decision-making in colleges and universities: The broad perspective. Journal of College and University Law, $1,241-263$.

Hasselbrinck, W. R. (1975). Higher court decisions related to faculty rights in higher education. Dissertation Abstracts Internationa1, 36, 7778-A.

Hedgepeth, R. C. (1974). Consequences of collective bargaining in higher education: An explanatory analysis. Journal of Higher Education, 45, $691-705$.

Hicks, H. G. (1967). The management of organizations. New York: McGraw-Hill.

Jackson, B. L., and Richardson, R. L. (1976). Legal issues in higher education: A look toward the future. Educational Forum, $\underline{40}, 187$. 
Jencks, C., \& Riesman, D. (1969). The academic revolution. Garden City, NY: Anchor Books.

Kemerer, F. R. \& Baldridge, J. V. (1975-76). The impact of faculty unions on governance. Change, $\underline{7}, 50-51,62$.

Kemerer, F. R. (1981). Senates and unions: Unexpected peaceful coexistence. Journal of Higher Education, 52, 256-264.

Kemerer, F. R., \& Baldridge, J.V. (1975). Unions on campus. San Francisco: Jossey-Bass.

Kerr, C. (1963). The uses of the university. New York: Harper and Row.

Krueger, Anne 0. (1979). The changing economic status of the profession and the impact of inflation. Academe, 65, 487-492. Ladd, E. C. \& Lipset, S. M. (1973). Professors, unions and higher education. Berkeley: Carnegie Foundation.

Lee, B. A. (1977). The effect of faculty collective bargaining on academic governance in four-year colleges and universities. Dissertation Abstracts International, 38, 4606.

Lee, B. A. (1979). Governance at unionized four-year colleges:

Effects on decision-making structures. Journal of Higher Education, 565-585.

Lee, B. A. (1982). The Yeshiva decision: An ultimatum for professionals. New York University Educational Quarterly, 13, $21-28$.

Levine, M. J., \& Hagburg, E. C. (1979). Public sector labor relations St. Paul: West Publishing Company. 
Lieberman, M. (1975, October). Professors united! Harper's Magazine, pp. 61-70.

Linney, T. J. (1979). Alternatives to tenure. AAHE-Eric/Research Currents. Washington DC: U.S. Department of Health, Education and Welfare. (ERIC Document Reproduction Service No. HW 610 $995)$.

Liowenthal, A., \& Nelson, R. (1976). Bargaining for academic democracy. Washington DC: American Federation of Teachers (ERIC Document Reproduction Service No. ED 169817 ).

Lipset, S. M. (1975). Faculty unions and collegiality. Change, $\underline{7}$, p. 39 .

Lozre, G. G. \& Mortimer, K. P. (1976). A collective bargaining election: Issues and faculty voting behavior. Research in Higher Education, 4, 193-208.

McHugh, W. F. (1971). Collective bargaining with professionals in higher education. Wisconsin Law Review, 1, 55-90.

Mctiugh, W. F. (1973). Faculty unionism. In B.L. Smith, The tenure debate. San Francisco: Jossey-Bass.

Macroff, G. I. (1980). Taking stock after Yeshiva. Educational Record, 61, 14-18.

Mason, H. L. (1982). Four issues in contemporary campus governance. Academe, 68, 3A-14A.

Menard, A. P. (1979). Are faculty members scholars or managers? The Yeshiva case. Labor Law Journal, 30, 754-767. 
Meskill, L. D., \& Meskill, V. P. (1977). Research in review.

Educational Leadership, 35, 229-232.

Millett, J. D. (1975). Higher education management versus business management. Educationa1 Record, 56, 221-225.

Millett, J. D. (1982). Multicampus governance in the $80 \mathrm{~s}$. AGB Reports, 24, 22-27.

Mortimer, K. P. et. al. (1976). Perceiving legitimacy of decision making and academic governance patterns in higher education. Research in Higher Education, 4, pp. 273-290.

Mortimer, K. P. \& Richardson, R. C. (1977). Governance in institutions with faculty unions: Six case studies. University Park, PA: Center for study in higher education.

Moskow, M. H. (1971). The scope of collective bargaining in higher education. Wisconsin Law Review, 1 , 33-54.

Nachmias, D., \& Rosenbloom, D. H. (1980). Bureaucratic government USA. New York: St. Martin's Press.

Napolitano, F. A. (1978). A study of the perception of key administrators and faculty of the effects of collective bargaining on governance in institutions of higher education. Dissertation Abstracts International, 40, 125 .

Nelson, J. L. (1982). Collective bargaining's myths as realities. Academe, 9-11.

Olson, J. K. (1974). Governance by confrontation: Adversarialism at the university. Intellect, 102, 361-364. 
Paxton, D. R. \& Thomas, D. L. (1977). College president's role performance and faculty satisfaction. Research in Higher Education, 7, 341-353.

Peters, T. J., \& W., R. H. (1981). In search of excellence. New York: Harper \& Row.

Polishook, I. H. (1982). Unions and governance -- the CUNY experience. Academe, 14-16.

Polishook, I. H. (1982). The union as an elected participatory body. Academe, 9A-12A.

Pollay, R. W., Taylor, R. N.; \& Thompson, M. (1976). A model for horizontal power sharing and participation in university decision-making. Journal of Higher Education, 47, 141-155.

Prater, R. (1963). The college president. Washington, DC: Center for Applied Research in Education.

Rehdel, R. R. (1979). The bureaucratic drift in the governance of higher education: Insights from organizational theory. Educational Technology, 19, 7-15.

Richman, B. M., \& Farme, R. N. (1974). Leadership, goals, and power in higher education. San Francisco: Jossey-Bass.

Ringer, F. (1980). Academic governance and collective bargaining. Academe, 66, 41-44.

St. John, 0. (1976). Court decisions relevant to collective bargaining and their implications for the governance of higher education. Dissertation Abstracts International, 37, 2020-A. 
Sachs, L. (1982). Applied Statistics. New York: Springer-Verlag.

Salancik, G. R. \& Pfeffer, J. (1977). Who gets power - And how they hang onto it: A strategic-contingency model of power.

Organizational Dynamics, 3-21.

Sands, C. D. (1971). The role of collective bargaining in higher education. Wisconsin Law Review, 1, 150-176.

Schwartzman, H. D. (1974). The administration's approach to collective bargaining. Journal of College and University Law, 1 , $351-369$.

Seredick, M. S. (1978). Collective bargaining and academic governance at five Michigan universities. Dissertation Abstracts International, 39,3410 .

Shanke, A. (1978). Unions and the academic enterprise. Washington, DC: American Federation of Teachers. (ERIC Document Reproduction Service No. ED 169 818).

Sherman, F. E., \& Loeffler, D. (1971). The teaching assistants association - University of Wisconsin experience: A tripartite analysis. Wisconsin Law Review, 1, 157-209.

Shulman, C. H. (1979). Old expectations, new realities: The academic profession revisited. (AAHE-ERIC/Higher Education Research Report No. 2). Washington, DC: American Association for Higher Education, 1979. (ERIC Document Reproduction Service No. ED 169874 ).

Simpson, W. A. (1976). Tenure: a perspective of past, present, and future. Educational Record, 56, 48-54. 
Sisk, H. L. (1979). Principles of management. Cincinnati: South-Western.

Smith, B. L. (1973). The tenure debate. San Francisco: Jossey-Bass.

Spinrad, W. (1984). A pathway to shared authority: collective bargaining and academic governance. Academe, 70, 29-34. SPSS $\underline{x}$ User's Guide. (1983). San Francisco: McGraw Hill. State of Oregon. (1982). Rules employment relation board, Oregon adminstration rules.

Thornton, J. W. (1981). A study to determine the effects of collective bargaining on faculty participation in institutional governance in Roman Catholic related four-year institutions of higher education. Dissertation Abstracts Ir.ternational, 42, 4742 .

Strihm, P. (1981). Faculty governance in the $80 \mathrm{~s}$ : Adverse conditions, diverse responses -- A preliminary wingspread report. Academe, 67, 383-386.

Tumninia, P. A. (1979). An assessment of the impact of collective bargaining on academic governance with New Jersey public institutions of higher education. Dissertation Abstracts International, 40, 2510 .

Vaccaro, L. C. (1972). The tenure controversy: Some possible alternatives. Journal of Higher Education, 43, $35-43$. VanDyck, H. D., \& Gortese, T., (1979). Should tenure be abolished? Instructor, 88,40 . 
Vockel1, E. L. (1983). Educational research. New York: Macmillan.

Weber, M. (1947). The theory of social and economic organization.

New York: Oxford University Press.

Welley, M. M. (1979). The art of administration: Flexibility and modificability are its essential characteristics. Journal of Higher Education, 50, 559-564.

Wollett, D. H. (1971). The status and trends of collective

negotiation for faculty in higher education. Wisconsin Law Review, $1,2-32$.

Zar, J. H. (1984). Biostatistical analysis. Salt Lake City, Utah: Prentice Hall.

\section{Interviews}

Bledsoe, G. B. (1984, October) [Interview with Geri. B. Bledsoe, Associate General Secretary: AAUP Collective Bargaining], Washington, D.C.

Cunningham, D. (1983, October). [Telephone interviews with David Cunningham, director of the Academic Collective Bargaining Information Service], University of District of Columbia. Grahill, S. (1984, October) [Interview with Sue Grahill, Collective Bargaining Coordinator: AAUP Collective Bargaining], Washington, D.C.

Kahananui, C. (1983, October) [Telephone Interview with Clarethel Kanhananui, Acting Vice Chancellor, Academic Affairs], Oregon System of Higher Education. 
Lee, B. (1983, October) [Telephone Interview with Barbara Lee, Assistant Professor], Rutgers University. 
APPENDICES 
APPENDIX A

THE RESEARCH INSTRUMENT 


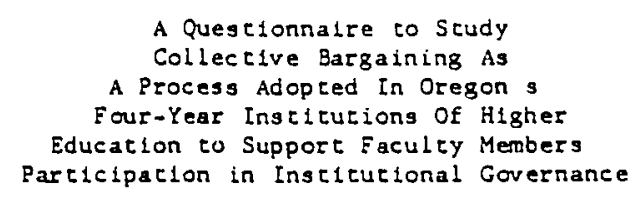

A. Eaculcy Questonnalre

I Respondent Information

Please read each statement carefully Check the answer(s) for each item as it best applies to you as a full-time faculey member in your universicy syscem during the 1983-1984 academic year

1 How many years have you taughe full time in a four-year institution of higher education?

$$
\begin{array}{ll}
\text { a } & 1-4 \text { years } \\
\text { b. } & 5-10 \text { years } \\
\text { c. } & 11-15 \text { years } \\
\text { d. } & 16-20 \text { years } \\
\text { e. } & 21-25 \text { years } \\
\text { f. Over } 25 \text { years }
\end{array}
$$

2 Are you a member of Aalu? .

$$
\text { a. Yes }
$$

b. No

3 For the 1983-84 academic year indicate the range below for your 9 months salary
a. $\$ 10000-\$ 15000$
b $\$ 16000-\$ 20000$
c $\$ 21000-\$ 25000$
$\$ 26000-\$ 30000$

$$
\left[\begin{array}{ll}
{[} & ] \\
{[} & ] \\
{[} & ]
\end{array}\right.
$$

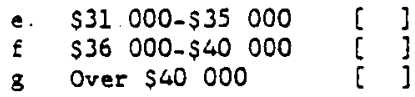

4. Durtng the 1983-1984 academic year are you serving as a member of one or more of the university/departmental acaderic governing bodies listed below?

Faculty Academic Senate

Finance Comititee

Rank and Tenure Cormicree

other policy-making Camitree Specify

5. What is your age range?
a $\quad 20-29$
b. $30-39$
c. $40-49$
d. $50-59$
e. 60 or above

6. How involved have you been with the collective bargaining process in your ingtitution?
a Slightly active
Active
Very acilve
No involvement 
II Institutional Influences

Listed below are factors that might influence a faculty member to select collective bargaining Please read each starement carefully Declde whecher you strongly agree agree are undectded. disagree or strongly disagree that the factor raised below influenced you as a $f a c$ ulty member to vote for the renewal of the collectlve bargaining contract for your lnstitution in June of 1983

7 The instituction was experiencing a decline in student enrollment

8. State legislature funding was reduced for your institution.

9 Federal funds approprtated for research have been reduced.

10. The structural size of the insticution had grown rapldly during the preceding five years

11. Limited inseltutional funds have decreased the development of academic programs.

12 The central administration had experienced a reduced auconony in policy-making decistons for the institurion.

13 The educational policy decision-making rights of the insticution s central administration were controlled by the state educational agency

14 The faculty academic senate/ council has become less effective as a governance body

15 There was a decline in the faculty members influence on policy decision-making at the depar imental level

16. There was a reduced sense of collegialley among the faculty

17. Student power has increased on the campus

18. The institution has developed and implemented a new mission and goal scatements

19. The institution has designed and implemented a new organizactional structure.

\begin{tabular}{|c|c|c|c|c|c|c|c|c|c|}
\hline \multicolumn{2}{|c|}{$\begin{array}{l}\text { Strongly } \\
\text { Agree }\end{array}$} & \multicolumn{2}{|c|}{ Asree } & \multicolumn{2}{|c|}{$\begin{array}{l}\text { Unde- } \\
\text { eided }\end{array}$} & \multicolumn{2}{|c|}{$\begin{array}{l}\text { Dis- } \\
\text { agree }\end{array}$} & \multicolumn{2}{|c|}{$\begin{array}{l}\text { Strongly } \\
\text { Disagree }\end{array}$} \\
\hline[ & I & {[} & ] & {[} & ] & {[} & ] & {[} & ] \\
\hline[ & ] & {[} & ] & {[} & ] & {[} & 3 & {[} & ] \\
\hline[ & ] & {[} & ] & {[} & ] & $l$ & J & {[} & ] \\
\hline[ & 1 & {[} & J & {[} & 3 & {[} & I & {[} & ] \\
\hline[ & ] & $\zeta$ & ] & {[} & ] & {[} & J & {[} & 3 \\
\hline[ & ] & {[} & ] & {[} & 3 & {[} & J & {[} & ] \\
\hline [ & ] & {[} & J & {[} & J & {[} & J & {[} & I \\
\hline[ & I & [ & 1 & c & ] & {[} & ] & {[} & ] \\
\hline[ & 1 & {[} & ] & {[} & ] & {[} & I & {[} & I \\
\hline[ & ] & {[} & ] & {[} & J & {[} & ] & {[} & ] \\
\hline[ & J & {[} & I & {[} & ] & l & ] & {[} & ] \\
\hline [ & ] & {[} & I & {[} & I & [ & 3 & {[} & J \\
\hline[ & ] & {[} & ] & {[} & ] & {[} & ] & {[} & ] \\
\hline
\end{tabular}


II Ingtitutional Governance Information

\section{$A$ Profesgional Incerests}

Please read each statement carefully Decide whether you strongly agree agree are undeelded disagree or girongly disagree that academic collective bargaining has provided you with.

20 An academic milieu supportive of the incellectual pursult of scholarship

21 A collegial relarionstip wich administracton

22 A formalized structure and process for insttutional dectsion-making

23 A professional rather than employee status to their role in the insticution

24 An increased incerest in the function and role of the faculty genate/council

25 An influence in setting lnsticutional standards for academic performance

26 Involvement in the selection process for the appointment of an administrator to a central or departmental administrative position

27 The right to participation in policy making on educational issues that have the potential to affect public opinion about the institution

\begin{tabular}{|c|c|c|c|c|c|c|c|c|c|}
\hline \multicolumn{2}{|c|}{$\begin{array}{l}\text { Strongly } \\
\text { Agree }\end{array}$} & \multicolumn{2}{|c|}{ Agree } & \multicolumn{2}{|c|}{$\begin{array}{l}\text { Unde- } \\
\text { cided }\end{array}$} & \multicolumn{2}{|c|}{$\begin{array}{l}\text { Dis- } \\
\text { agree }\end{array}$} & \multicolumn{2}{|c|}{$\begin{array}{l}\text { Serongly } \\
\text { Disagree }\end{array}$} \\
\hline [ & ] & {[} & I & {[} & I & [ & ] & [ & ] \\
\hline[ & ] & {[} & I & {[} & ] & {[} & ] & {[} & ] \\
\hline [ & ] & {[} & 1 & [ & ] & {[} & ] & {[} & I \\
\hline[ & ] & [ & ] & [ & ] & {[} & ] & {[} & I \\
\hline [ & ] & [ & $I$ & {[} & ] & [ & ] & {[} & ] \\
\hline[ & ] & {[} & I & {[} & I & l & ] & {[} & J \\
\hline[ & ] & {[} & 1 & {[} & 1 & {[} & ] & [ & I \\
\hline c & 1 & c & ] & {[} & ] & {[} & ] & [ & 1 \\
\hline
\end{tabular}


3. Economic Interests

Please read each statement carefully Decide if you strongly agree agree are undecided disagree or scrongly disagree that in your insticucion the collective bargaining process has.

28 Provided you with a high public profile regarding budgetary issues in Oregon's system of higher education.

29 Clariffed the problen of a low faculty salary schedule in Oregon s system of higher education

30 Increased the importance of the budgetary/ financlal affatis comitree sole in univergity budget analysis and planning

31 Strengthened your input into short-range university budget planning and decision-making

32 Provided for your input into the long-range budgetary planning model of the university

33 Encouraged the university budgetary affairs comitree to link university budget planning to the identified institution $g$ academic goals

34 Assisted the faculty and administration to present a united agreement to the gtace legisiature

35 Generated additional moncy for the university faculty salary schedule in Oregon s system of higher education

\begin{tabular}{|c|c|c|c|c|c|c|c|c|c|}
\hline \multicolumn{2}{|c|}{$\begin{array}{l}\text { Strongly } \\
\text { Agree }\end{array}$} & \multicolumn{2}{|c|}{ Agree } & \multicolumn{2}{|c|}{$\begin{array}{l}\text { Unde- } \\
\text { cided }\end{array}$} & \multicolumn{2}{|c|}{$\begin{array}{l}\text { Dis- } \\
\text { agree }\end{array}$} & \multicolumn{2}{|c|}{$\begin{array}{l}\text { Strongly } \\
\text { Disagree }\end{array}$} \\
\hline[ & ] & l & ] & {[} & 1 & {[} & ] & {[} & I \\
\hline[ & ] & {[} & J & 6 & J & {[} & ] & {[} & J \\
\hline[ & ] & {[} & J & {[} & I & {[} & ] & [ & ] \\
\hline[ & $\mathrm{J}$ & {[} & ] & {[} & ] & {[} & J & c & ] \\
\hline[ & ] & {[} & I & {[} & ] & {[} & ] & [ & ] \\
\hline [ & J & {[} & J & {[} & ] & {[} & ] & {[} & ] \\
\hline [ & ] & [ & ] & {[} & ] & {[} & J & {[} & I \\
\hline [ & ] & [ & I & {[} & ] & {[} & ] & {[} & ] \\
\hline [ & ] & {[} & ] & {[} & ] & {[} & ] & {[} & ] \\
\hline
\end{tabular}

6 Increased your galary and Ertnge benefits package in the university system 
C Educacional Policies

Please decide if you strongly agree agree are undecided disagree or grrongly disagree that collective bargalning has provided you with an opportunity ro determine educational policies related to the following academic issues:

\begin{tabular}{|c|c|c|c|c|c|c|c|c|c|c|}
\hline & & $\begin{array}{l}\text { Strongly } \\
\text { Agree }\end{array}$ & Agr & & $\begin{array}{l}\text { Und } \\
\text { eld }\end{array}$ & & $\begin{array}{l}\text { Dis. } \\
\text { agr }\end{array}$ & s- & $\begin{array}{l}\text { Str } \\
\text { Dis }\end{array}$ & $\begin{array}{l}\text { ongly } \\
\text { agree }\end{array}$ \\
\hline 37. & Admisston Standards & {[]} & {[} & ] & {[} & ] & {[} & 1 & 〔 & ] \\
\hline 38 & Curriculum Concent & {[]} & {[} & ] & {[} & ] & {[} & ] & {[} & ] \\
\hline 39 & Degree Requirements & ] & {[} & ] & {[} & ] & {[} & ] & 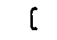 & ] \\
\hline 40 & Grading Standards & {[} & {[} & ] & {[} & ] & {[} & ] & {[} & ] \\
\hline 41 & Standards for Student Conduct and Discipline & {[} & {[} & 了 & {[} & ] & {[} & ] & {[} & ] \\
\hline 42 & Types of Degrees Offered & {[} & {[} & ] & {[} & I & {[} & ] & {[} & 1 \\
\hline 43 & Establishment of Educational Programs & {$[\quad]$} & {[} & 了 & {[} & 1 & {[} & ] & {[} & ] \\
\hline
\end{tabular}

D Academic and Personnel Pollcles

Listed below are academic and personnel policies which AAUP belleves faculty members should govern Please decide if collective bargaining has provided the faculcy members employed in your institution with the opportunity to always frequencly infrequently or never participate in decermining policies related to the following issues.

$1 \quad$ Academic Duties

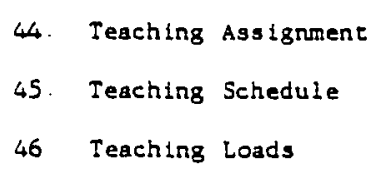

Always Frequently Infrequently Never

Academic Standards/Personnel Policies for

\begin{tabular}{|c|c|c|c|c|c|c|c|c|}
\hline 47. & Facul ty Recrul tment & {[} & ] & {[} & ] & {[} & ] & {[} \\
\hline 48. & Eaculty Promorion & {[} & ] & 〔 & 1 & {[} & ] & {[} \\
\hline 49 & Faculty Tenure & {[} & ] & {[} & ] & {[} & ] & {[} \\
\hline 50 & Academic Freedom & {[} & ] & [ & ] & {[} & ] & {[} \\
\hline 51 & Digmissal for Cause (Just Cause) & {[} & ] & {[} & 1 & {[} & ] & {[} \\
\hline 52 & Salary Scale & {[} & ] & {[} & ] & {[} & I & {[} \\
\hline 53 & Fringe Benefits & $\zeta$ & 了 & {[} & 了 & \lceil & ] & {[} \\
\hline 54. & Grlevance Procedures & 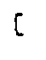 & ] & {[} & ] & c & ] & {[} \\
\hline \multicolumn{9}{|c|}{ Support Services } \\
\hline 55 & Office Space & {[} & 3 & {[} & ] & {[} & ] & {[} \\
\hline 56 & Secretarial help & {[} & 1 & {[} & ] & {[} & ] & {[} \\
\hline
\end{tabular}

Thank you very auch for participating in this research study would you like to receive an abstract of the study?

$$
1 / \text { Yes } 11 \text { no }
$$


APPENDIX B

FINDINGS SPECIFIC TO THE 1969 CARNEGIE COMMISSION ON HIGHER EDUCATION SURVEY 


\section{FACULTY ATTITUDES TOWARD COLLECTIVE BARGAINING AND UNIONISM, BY PROFESSIONAL CHARACTERISTICS AND REWARDS; AS PERCENTAGES OF n (LADD AND LIPSET, 1973).}

The 1969 Survey

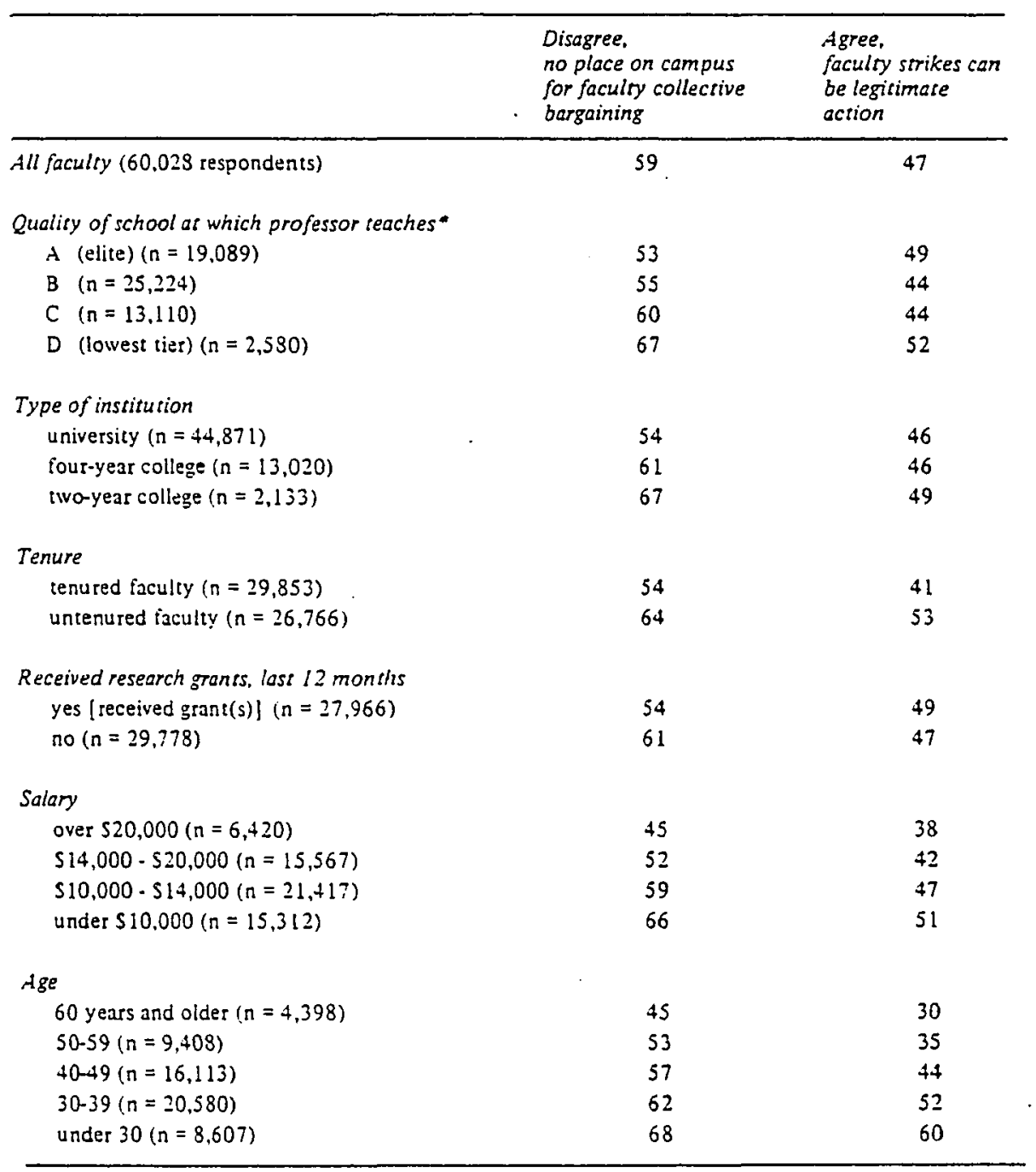




\section{APPENDIX C}

HUMAN SUBJECTS RESEARCH REVIEW

COMMITTEE APPROVAL LETTER 
HIMAN SUBUECTS RESEARCY REVIEW COMMTITEE

1982-83

TO: Patricia Chadwick - ED

FROM: Robert Holloway, Chairperson

In accordance with your request, the Euman Subjects Research Revlew Comittee has reviewed your proposal ent1tled, "Collective Bargaining: A brpcess Adopted by Oregon's Four-Year Institutions of Higher Education..."

for compllance with DEEW pollcles and regulations on the protection of human subjects.

The commtttee ts satigfied that your provisions for protecting the rights and welfare of all subjects particlpating in the research are adequate and therefore the project is approved. Any condltions relattve to this approval are noted below.

Cond1t1ons: NONE

cc: Office of Graduate Studles and Research 
APPENDIX D

DATA COLLECTION INFORMATION LETTER FROM THE OFFICE OF INSTITUTIONAL RESEARCH OFFICE AT PORTLAND STATE UNIVERSITY 


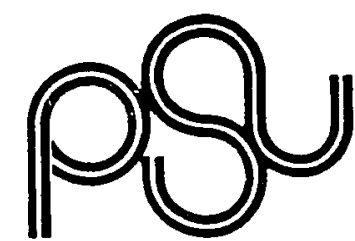

May 17,1984

Pat Chadwick, Dean

School of Nursing

University of Portland

$5000 \mathrm{~N}$. Willamette Blvd.

Portland, Oregon 97203

Dear Dean Chadwick:

Attached are the lists of faculty from Portland State University, Southern Oregon State College, and Western Oregon State College, which you requested for use in gathering data for your doctoral dissertation. The criteria which were used in selecting faculty for the lists are as follows:

- Hire date (Personnel Data Base element \#27) prior to $12 / 31 / 78$

- Holds an academic appointment for FY 83-84 at a total FTE .50 or greater (PDB element $\# 44$ )

- Is on an annual tenure (tenure-track) or indefinite tenure appointment (POB element $\ddot{\pi} 56$ )

The data base used for selection was extracted from the November 8, 1983 payroll tapes for the subject institutions and is the same data base which was provided to those institutions for purposes of EEO-6 reporting for Fal1 1983.

Please call me if I can be of further assistance.

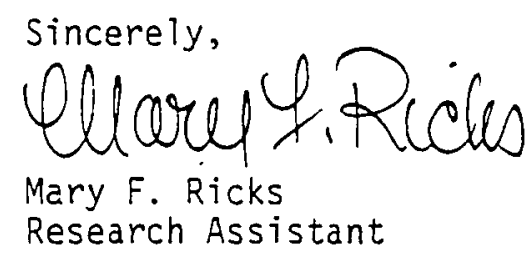

MFR:gh

Enclosures

xc: James H. Beaird, Provost

Western Oregon State College

Ernest E. Ettlich, Dean of Acad. Affairs

Southern Oregon State College

Don E. Gardner, Director

Office of Institutional Research

Portland State University 
APPENDIX E

INSTITUTIONAL APPROVAL LETTERS FOR DATA COLLECTION 


\section{늘 WOSC}

Office of the Provost
154
154

$1 \cdot i$.

.USTMijTiratA!

May 11, 1984

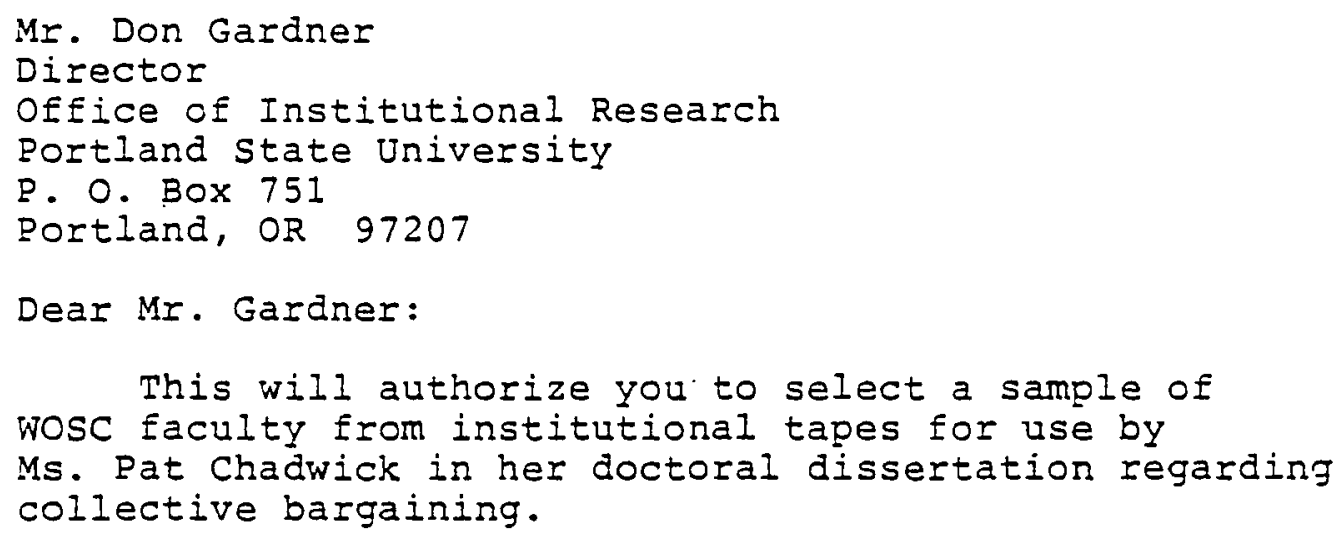

Dear Mr. Gardner:

This will authorize you to select a sample of wosc faculty from institutional tapes for use by

Ms. Pat Chadwick in her doctoral dissertation regarding collective bargaining.

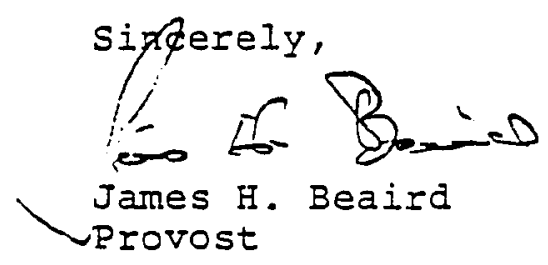

$\mathrm{JHB} / \mathrm{tn}$ 


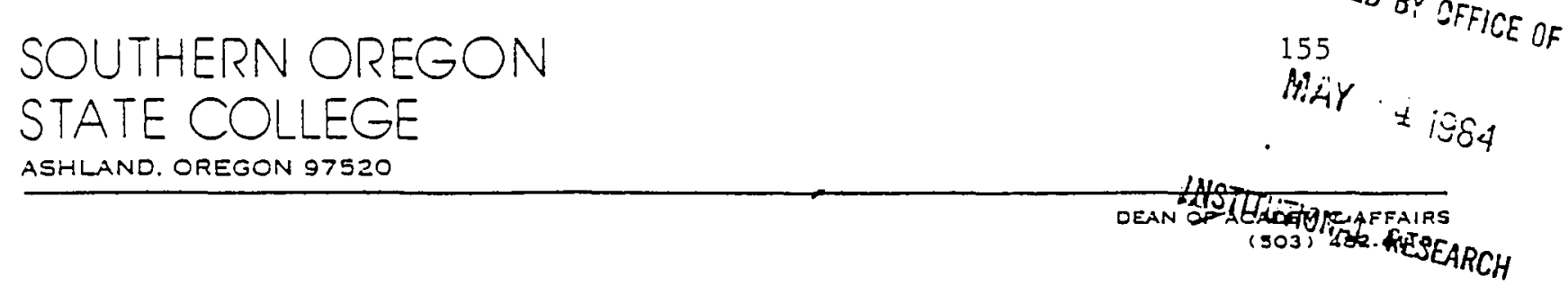

May 10,1984

Mr. Don Cardner

Director of Insticutional Research

Portland State University

302 Universicy Services Building

Eortland OR 97207

Dear Mr. Gardner:

Professor Walt Ellis called on May 9 asking permission for a random structured sample of our faculty to be drawn for a study being conducted in education. Pat Chadwick will be doing a dissertation under Professor Ellis which deals with faculty attitudes coward collective bargaining.

This letter is to grant permission for such a structured sample to be taken while protecting the confidential elements within the personnel files and tapes.

I would appreciate receiving a copy of the results of the study when Ms. Chadwick has compleced it.

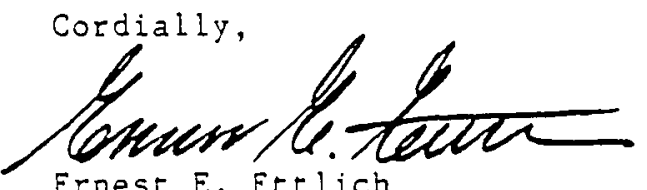

Ernest E. Eetlich

Dean of tcademic Affairs

pkj 
APPENDIX F

APPEAL LETTER TO SUBJECTS FOR WAVE ONE OF THE DATA COLLECTION 
PORTLAND

STATE

UNIVERSITY

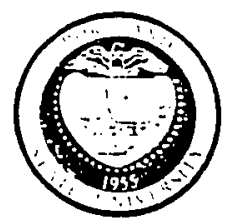

157

P.O. BOX 751

PORTLAND, OREGON

97207

May 18,1984

I am writing to request your participation in my doctoral dissertation research. The study has been approved by the University Human Subjects Research Review Committee and by my dissertation committee chaired by Dr. Walter G. Ellis, Professor of Public Administration.

The purpose of the research study is to evaluate whether or not the adoption of collective bargaining as a supplemental governance mode by three of Oregon's four-year institutions of higher education has provided support for faculty members to participate in institutional governance. Selected faculty members with academic appointments at Portland State University, Southern Oregon State College, and Western Oregon State College are being asked to participate in the study.

Please take 15 minutes to complete and return the enclosed questionnaire by May 31, 1984, in the stamped, self-addressed envelope. All the information which you provide in response to the questionnaire, will be kept confidential and anonymous. The uumbers on the upper right-hand corner of the questionnaire represent a code, which will be used only to enable a follow-up on unreturned questionnaires.

I realize that this is a very busy time in the academic year; however, your response will assist in my research and hopefully add to the evaluation of collective bargaining as a supplemental governance mode in the Oregon university system of higher education.

If you have any questions or concerns about the questionnaire or the study, please call me at 283-7211. Thank you in advance for your time and assistance with this doctoral research study.

Sincerely,

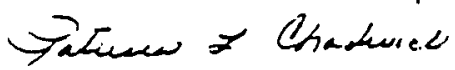

Patricia L. Chadwick

Doctoral Candidate

School of Education

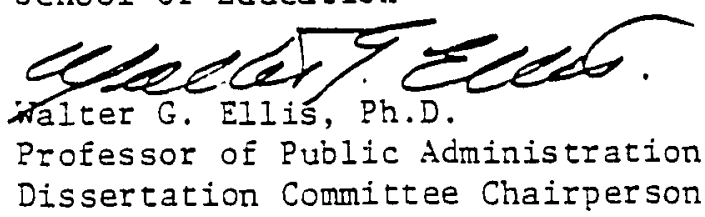


APPENDIX $G$

FOLLOW-UP APPEAL MATERIAL TO SUBJECTS FOR WAVES

TWO AND THREE OF THE DATA COLLECTION 
May 28, 1984

Dear Professor:

This past week, I wrote to request your participation in my doctoral dissertation research. The study is designed to evaluate collective bargaining as a supplemental governance mode in the Oregon university system of higher education.

As you plan your week of May 28, 1984, will you please allow 15 minutes in your schedule to complete the questionnaire for the study? Thank you.

Gatuen ro. Chander

Patricia L. Chadwick

Doctoral Candidate

School of Education

Portland State University 
PORTLAND

STATE

UNIVERSITY
160

P.O. BOX $75 i$ PORTLAND. ORECON 97207

June 4, 1984

Dear

Two weeks ago, I wrote to request your participation in my doctoral dissertation research. The study has been designed to evaluate whether or not the adoption of collective bargaining as a supplemental governance mode by three of oregon's four-year institutions of higher education has provided support for faculty members to participate in institutional governance.

To date, I have not received your completed questionnaire; therefore, I would like to once again appeal for your participation in my study.

For your convenience, I am sending a new copy of the questionnaire, as well as a stamped, self-addressed envelope. The questionnaire will take approximately 15 minutes of your time to complete. All the information which you provide in response to the questionnaire, will be kept confidential and anonymous.

If you have any questions about the study, please call me at 283-7211 or my dissertation committee chairperson, Dr. Walter G. Ellis, Professor of Public Administration at 229-3920. study.

Thank you for considering my request to participate in this doctoral research

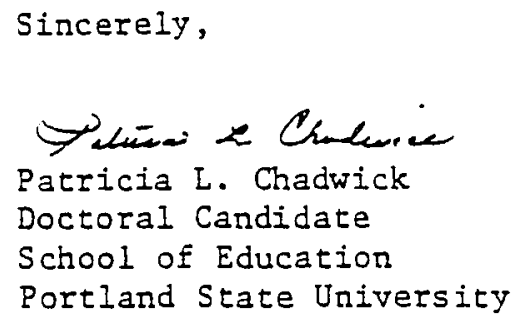

PIC:bcb

Enclosures 
APPENDIX H

RESPONDENT CODEBOOK FOR THE $\left(\right.$ SPSS $\left._{X}\right)$ DATA ANALYSIS 
Respondent Codebook - Collectlve Bargaining As A Process Adopted

in Oregon's Four-Year Insticutions of Higher Education to Support

Faculty Merbers' Parelclpation in Instituflonal Governance

\begin{tabular}{|c|c|c|c|c|}
\hline CARD & COLUNNS & QUESTION & VAR IABLE & CODE \\
\hline \multirow[t]{11}{*}{1} & 1 & $\wedge$ & & \\
\hline & $2-4$ & B & Respondent ID \# & Put Number \\
\hline & 5 & c & Institution & $\begin{array}{l}1 \ldots \text { wOSc } \\
2 \ldots \text { sosc } \\
3 \ldots \text { PSU }\end{array}$ \\
\hline & 6 & $D$ & $\begin{array}{l}\text { School / Department } \\
\text { of Appolntment }\end{array}$ & $\begin{array}{l}\text { 1... Liberal arts Department/College } \\
\text { 2... College of Liberal Arts \& Sciences } \\
3 \text {... Professional School } \\
\text { 4... Others }\end{array}$ \\
\hline & & E & Dace of Response & Year -84 - No Reaponse \\
\hline & 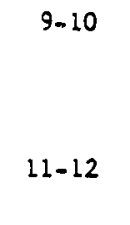 & & & $\begin{array}{c}\text { Month - } 05 \text { May } \\
06 \text { June } \\
07 \text { July } \\
08 \text { Auguat } \\
9 \text { - No Reaponse } \\
\text { Date - } 01-31 \\
9 \text { - No Response }\end{array}$ \\
\hline & 13 & $\boldsymbol{F}$ & $\begin{array}{l}\text { Response Received } \\
\text { With: }\end{array}$ & $\begin{array}{l}\text { 1... F1rst Have } \\
2 \ldots \text { Second Have } \\
3 \ldots \text {. Third Wave } \\
4 \text { - No Reoponse }\end{array}$ \\
\hline & 14 & G & Academic Rank & 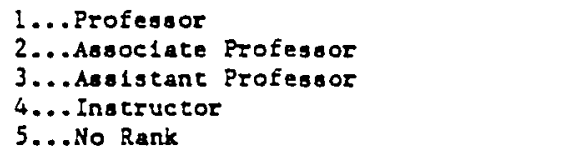 \\
\hline & 15 & 1 & Full-Itge Teaching & $\begin{array}{l}1 \ldots 1-4 \text { years } \\
2 \ldots 5-10 \text { years } \\
3 \ldots 11-15 \text { years } \\
4 \ldots 16-20 \text { years } \\
5 \ldots 21-25 \text { years } \\
6 \ldots \text {...0ver } 25 \text { years } \\
9 . . \text {. No Response }\end{array}$ \\
\hline & 16 & 2 & AAUP Menbership & $\begin{array}{l}1 \ldots \text { Yes } \\
2 \ldots \text { No } \\
9 . . \text {.No Response }\end{array}$ \\
\hline & 17 & 3 & $\begin{array}{l}1983-1984 \text { Academic } \\
\text { Year } 9 \text { mo. Salary }\end{array}$ & $\begin{array}{l}1 \ldots 10,000-15,000 \\
2 \ldots 16,000-20,000 \\
3 \ldots 21,000-25,000 \\
4 \ldots 26,000-30,000 \\
5 \ldots 31,000-35,000 \\
6 \ldots 36,000-40,000 \\
7 \ldots \text { Over } 40,000 \\
9 \ldots \text { No Response }\end{array}$ \\
\hline
\end{tabular}




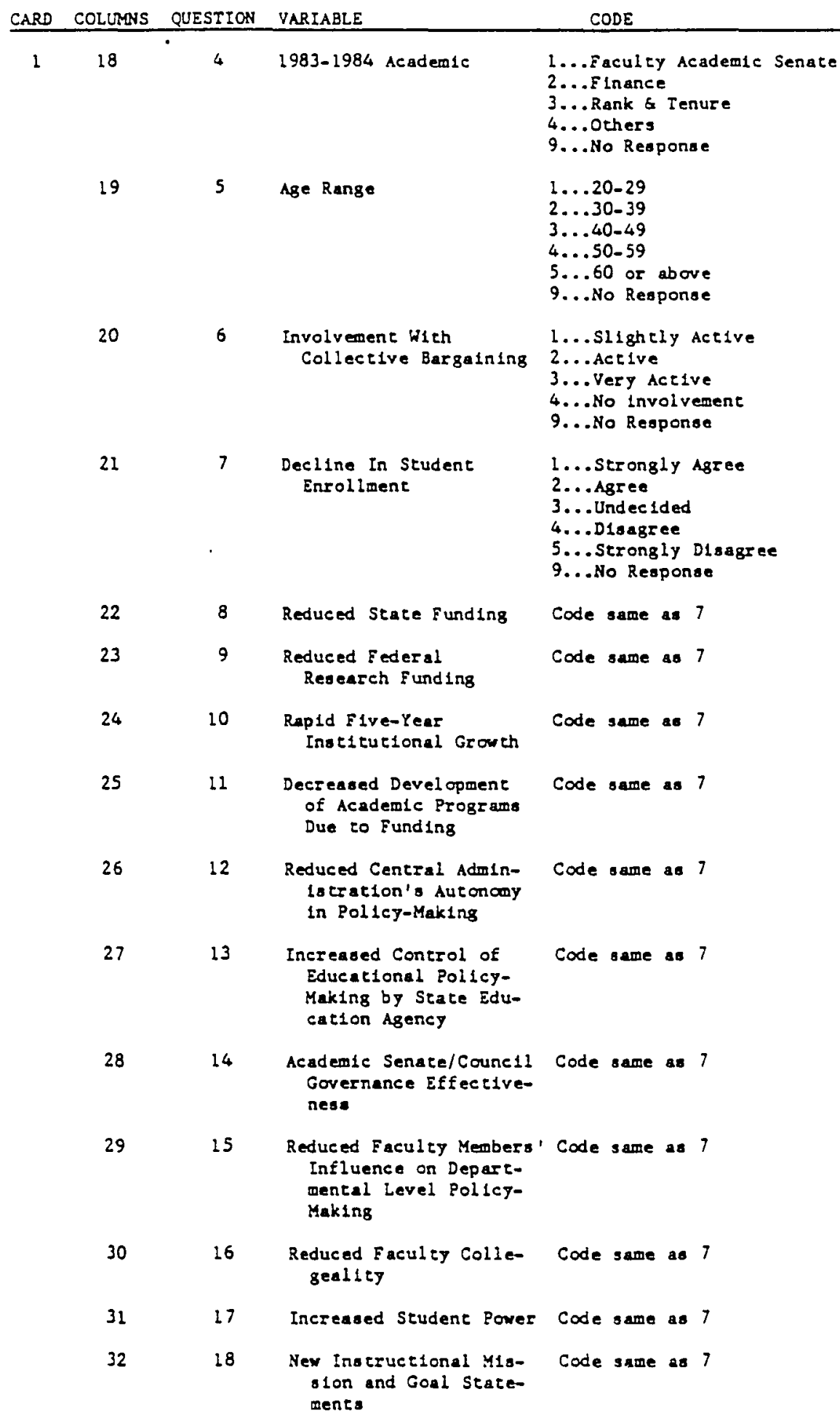




\begin{tabular}{|c|c|c|c|c|c|}
\hline CARD & COLLRNS & QUESTION & VARIABLE & CODE & \\
\hline \multirow[t]{16}{*}{1} & 33 & 19 & $\begin{array}{l}\text { New Inatructional or- } \\
\text { ganizational seruc- } \\
\text { ture }\end{array}$ & Code same as & 7 \\
\hline & 34 & 20 & $\begin{array}{l}\text { Academic Mil leu Support- } \\
\text { Ive of Scholarship }\end{array}$ & Code same as & 7 \\
\hline & 35 & 21 & $\begin{array}{l}\text { Collegial Relationship } \\
\text { vith Adminlatration }\end{array}$ & Code same as & 7 \\
\hline & 36 & 22 & $\begin{array}{l}\text { Formal Declalon-Making } \\
\text { Structure/Process }\end{array}$ & Code same as & 7 \\
\hline & 37 & 23 & $\begin{array}{l}\text { Profesolonal Status } \\
\text { Role }\end{array}$ & Code same as & 7 \\
\hline & 38 & 24 & $\begin{array}{l}\text { Increased Interest in } \\
\text { the Faculiy Senatel } \\
\text { Council }\end{array}$ & Code same as & 7 \\
\hline & 39 & 25 & $\begin{array}{l}\text { Influence in Seting } \\
\text { Standards for Academic } \\
\text { Performance }\end{array}$ & Code same an & 7 \\
\hline & 40 & 26 & $\begin{array}{l}\text { Involvement in the Ad- } \\
\text { ministrative Position } \\
\text { Selection Process }\end{array}$ & Code same as & 7 \\
\hline & 41 & 27 & $\begin{array}{l}\text { Particlpation in Educa- } \\
\text { tional Policy Iosues }\end{array}$ & Code same as & 7 \\
\hline & 42 & 28 & $\begin{array}{l}\text { High Public Profile Re- } \\
\text { garding Budgetary } \\
\text { Isoues }\end{array}$ & Code same as & 7 \\
\hline & 43 & 29 & $\begin{array}{l}\text { Clarificacion of Lou } \\
\text { Faculty Salary } \\
\text { Schedule }\end{array}$ & 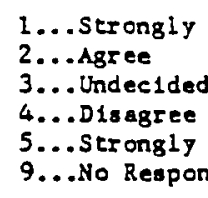 & $\begin{array}{l}\text { Agree } \\
\text { d } \\
\text { Dioagree } \\
\text { nse }\end{array}$ \\
\hline & 44 & 30 & $\begin{array}{l}\text { Importance of a } \\
\text { Budgetary/Financial } \\
\text { Camittee ln Univer- } \\
\text { alty Analgols/Planning }\end{array}$ & Code same as & 29 \\
\hline & 45 & 31 & $\begin{array}{c}\text { Input Inco Short-Range } \\
\text { Budgetary Planning }\end{array}$ & Cocie same as & 29 \\
\hline & 46 & 32 & $\begin{array}{l}\text { Input into the Long } \\
\text { Range Budgetary } \\
\text { Planning Model }\end{array}$ & Code same as & 29 \\
\hline & 47 & 33 & $\begin{array}{l}\text { Inkage of University } \\
\text { Budgetary Planning to } \\
\text { Academic Goals }\end{array}$ & Code same as & 29 \\
\hline & 48 & 34 & $\begin{array}{l}\text { United Faculty a Admin- } \\
\text { lotration gudgetary } \\
\text { Agreement to State } \\
\text { Leglalature }\end{array}$ & Code same as & 29 \\
\hline
\end{tabular}




\begin{tabular}{|c|c|c|c|c|c|}
\hline CARD & COLUMNS & QUESTION & VARIABLE & CODE & \\
\hline \multirow[t]{23}{*}{1} & 49 & 35 & $\begin{array}{l}\text { Increased Funding for } \\
\text { the Faculty Salary } \\
\text { Schedule }\end{array}$ & Code same a & as 29 \\
\hline & 50 & 36 & $\begin{array}{l}\text { Increased Faculty Salary } \\
\text { and Fringe Benef1t } \\
\text { Packnges }\end{array}$ & Code same & as 29 \\
\hline & 51 & 37 & Adonsolon Standards & Code same & es 29 \\
\hline & 52 & 38 & Curriculum Content & Code same a & as 29 \\
\hline & 53 & 39 & Degree Requizements & Code same a & as 29 \\
\hline & 54 & 40 & Grading Standards & Code same & as 29 \\
\hline & 55 & 41 & $\begin{array}{l}\text { Standards for Student } \\
\text { Conduct/Diacipline }\end{array}$ & Code ame : & as 29 \\
\hline & 56 & 42 & Iypes of Degrees offered & Code same a & as 29 \\
\hline & 57 & 43 & $\begin{array}{l}\text { Establ lahment of Edu- } \\
\text { cational Program }\end{array}$ & Code same a & as 29 \\
\hline & 58 & 44 & Teaching Aolignment & $\begin{array}{l}\text { 1... Always } \\
2 \ldots \text {.. Irequen } \\
3 . . . \text { Infrequ } \\
\text { 4... Never } \\
\text { 9... No Resp }\end{array}$ & $\begin{array}{l}\text { entig } \\
\text { quently } \\
\text { sponse }\end{array}$ \\
\hline & 59 & 45 & Teachling Schedule & Code same & as 44 \\
\hline & 60 & 46 & Teaching Loed & Code same & 8. 44 \\
\hline & 61 & 47 & Faculty Recruitment & Code same & as 44 \\
\hline & 62 & 48 & Faculty Promotion & Code ane a & as 44 \\
\hline & 63 & 49 & Faculity Ienure & Code same & as 44 \\
\hline & 64 & 50 & Academic Freedor & Code same: & 1644 \\
\hline & 65 & 51 & $\begin{array}{l}\text { Dismissel for Just } \\
\text { Cause }\end{array}$ & Code sume? & as 44 \\
\hline & 66 & 52 & Salary Scale & Code same: & a6 44 \\
\hline & 67 & 53 & Fringe Benefits & Code same & 0844 \\
\hline & 68 & 54 & Grlevance Procedures & Code same & as 44 \\
\hline & 69 & 55 & Offlce Space & Code same & as 44 \\
\hline & 70 & 56 & Secretarial Help & Code same a & a. 44 \\
\hline & 71 & 57 & Abstract Requeat & $\begin{array}{l}1 \ldots \text { Yes } \\
2 \ldots \text { No } \\
9 \ldots \text { No Reap }\end{array}$ & oponse \\
\hline
\end{tabular}




\section{APPENDIX I}

TABLE XXIV: FACULTY MEMBERS' PERCEPTIONS OF INSTITUTIONAL

INFLUENCES RELATED TO THE DECISION-MAKING TO

VOTE FOR A 1983 CONTRACT RENEWAL 
TABLE XXIV

FACULTY MEMBERS' PERCEPTIONS OF INSTITUTIONAL

INFLUENCES RELATED TO THEIR DECISION-MAKINC

TO VOTE FOR A 1983 CONTRACT RENEWAL

\begin{tabular}{|c|c|c|c|c|c|c|c|c|c|}
\hline \multirow{3}{*}{\multicolumn{2}{|c|}{ Insticutional influences }} & \multicolumn{8}{|c|}{ Frequency } \\
\hline & & \multicolumn{2}{|c|}{$\begin{array}{l}\text { Strongly } \\
\text { Agree }\end{array}$} & & & & \multicolumn{2}{|c|}{$\begin{array}{l}\text { Strongly } \\
\text { Disagree }\end{array}$} \\
\hline & & $\underline{N}$ & $\langle \%$ & $\underline{N}^{A g}$ & $(7)$ & $\underline{\mathrm{N}} \quad(\%)$ & $\begin{array}{l}\text { Nisagree } \\
N \quad(\%)\end{array}$ & $\underline{N}$ & $\begin{array}{l}(\%) \\
(\%)\end{array}$ \\
\hline \multicolumn{10}{|c|}{ Scacements } \\
\hline 7. & $\begin{array}{l}\text { The institution was } \\
\text { experiencing a de- } \\
\text { cline in student en- } \\
\text { rollment. }\end{array}$ & 26 & $(6.2 \%)$ & 109 & $(26.0) \%$ & $66(15.8 \%)$ & $132(31.5 \%)$ & 86 & $(20.5 \%)$ \\
\hline 8. & $\begin{array}{l}\text { Stace legistative } \\
\text { fund ing was reduced } \\
\text { for your institution. }\end{array}$ & 157 & $(37.1 \%)$ & 168 & $(39.2 \%)$ & $(7.1 \%)$ & $40 \quad(9.5 \%)$ & 28 & $(6.6 \%)$ \\
\hline 9. & $\begin{array}{l}\text { Federal funding appro- } \\
\text { priaced for research } \\
\text { have been reduced. }\end{array}$ & 32 & $(7.6 \%)$ & 88 & $(21.0 \%)$ & $111(26.5 \%)$ & $114(27.2 \%)$ & 74 & $(17.7 \%)$ \\
\hline 10. & $\begin{array}{l}\text { The structural size of } \\
\text { the institution had } \\
\text { grown rapidly during } \\
\text { the preceding fiscal } \\
\text { year. }\end{array}$ & 16 & $(3.9 \%)$ & 62 & $(15.1 \%)$ & $81(19.7 \%)$ & $152(36.9 \%)$ & 101 & $(24.5 \%)$ \\
\hline 11. & $\begin{array}{l}\text { Limited institutional } \\
\text { funds have decreased } \\
\text { the development of } \\
\text { academic programs. }\end{array}$ & 125 & $(29.6 \%)$ & 177 & $(41.8 \%)$ & $47(11.1 \%)$ & $48(11.4 \%)$ & 26 & $(6.2 \%)$ \\
\hline 12. & $\begin{array}{l}\text { The central adminis- } \\
\text { tration had experi- } \\
\text { enced a reduced au- } \\
\text { tonomy in policy- } \\
\text { making decisions } \\
\text { for the insticution. }\end{array}$ & 35 & $(8.4 \%)$ & 93 & $(22.5 \%)$ & $107(25.7 \%)$ & $118(28.3 \%)$ & 64 & $(15.4 \%)$ \\
\hline 13. & $\begin{array}{l}\text { The educational pol- } \\
\text { lcy decision-making } \\
\text { rights of the insti- } \\
\text { tution's central ad- } \\
\text { ministration were } \\
\text { controlled by the } \\
\text { state educational } \\
\text { agency. }\end{array}$ & 48 & $(11.5 \%)$ & 1246 & $(29.6 \%)$ & $98(23.4 \%)$ & $107(25.5 \%)$ & 42 & $(10.0 \%)$ \\
\hline 14. & $\begin{array}{l}\text { The faculty academic } \\
\text { senace/counct } 1 \text { has } \\
\text { become less effective } \\
\text { as a governance body. }\end{array}$ & 59 & $(14.0 \%)$ & 149 & $(35.4 \%)$ & $76(18.1 \%)$ & $102(24.2 \%)$ & 35 & $\left(8.3^{\circ}.\right)$ \\
\hline 15. & $\begin{array}{l}\text { There was a decline } \\
\text { in the faculcy mem- } \\
\text { bers' influence on } \\
\text { policy-making deci- } \\
\text { sions at the depart- } \\
\text { mental level. }\end{array}$ & 71 & $(16.9 \%)$ & 127 & $(30.2 \%)$ & $41 \quad(9.7 \%)$ & $128(30.4 \%)$ & 54 & $\left(12.8^{2}.\right)$ \\
\hline 16. & $\begin{array}{l}\text { There was a reduced } \\
\text { sense of collegial- } \\
\text { ity anong the faculty. }\end{array}$ & 72 & $(17.1 \%)$ & 148 & $(35.1 \%)$ & $61(14.5 \%)$ & $99(23.5 \%)$ & 42 & $110.0 \%$ \\
\hline 17 & $\begin{array}{l}\text { Stucent power has in- } \\
\text { sreased on the campus. }\end{array}$ & 2 & $(0.5 \%)$ & 43 & $(10.2 \%)$ & $70(16.0 \%)$ & $198(-7.0 \%)$ & 108 & $(25 . \%)$ \\
\hline
\end{tabular}


Table XXIV (continued)

\begin{tabular}{|c|c|c|c|c|c|c|}
\hline \multirow[b]{3}{*}{ Ingtitutional Influences } & \multicolumn{6}{|c|}{ Erequency } \\
\hline & \multicolumn{2}{|c|}{ Strongly } & & \multirow[b]{2}{*}{ Undecided } & & \multirow{2}{*}{$\begin{array}{l}\text { Strongly } \\
\text { Disagree } \\
N \quad(\%)\end{array}$} \\
\hline & $\begin{array}{c}\text { Agre } \\
\underline{N}\end{array}$ & $(\%)$ & $\underline{N}^{\text {Agree }}(\%)$ & & $\begin{array}{c}\text { Disagree } \\
\mathbb{N} \quad(\%)\end{array}$ & \\
\hline \multicolumn{7}{|l|}{ Statements } \\
\hline $\begin{array}{l}\text { 18. The institution has } \\
\text { developed and imple- } \\
\text { mented a new mission } \\
\text { and goal statement. }\end{array}$ & 12 & $(2.9 \%)$ & $96(22.9 \%)$ & $112(26.7 \%)$ & $135(32.2 \%)$ & $61(15.3 \%)$ \\
\hline $\begin{array}{l}\text { 19. The institution has } \\
\text { designed and imple- } \\
\text { mented a new organl- } \\
\text { zational structure. }\end{array}$ & 25 & $(6.0 \%)$ & $125(29.9 \%)$ & $102(24.4 \%)$ & $111(26.6 \%)$ & $55(13.2 \%)$ \\
\hline
\end{tabular}


APPENDIX J

TABLE XXX: FACULTY MEMBERS' PERCEPTIONS OF THE IMPACT OF ACADEMIC COLLECTIVE BARGAINING ON THEIR PROFESSIONAL INTERESTS IN INSTITUTIONAL GOVERNANCE 
IABS.E $\mathrm{xxx}$

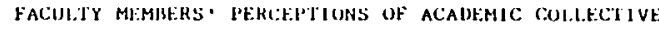

MARC:AINING:S IMPACIS UN THEITK PROFESSIUNA

\begin{tabular}{|c|c|c|c|c|c|c|}
\hline \multirow{3}{*}{$\begin{array}{l}\text { In:ticutional Covernance } \\
\text { Protesstonal linterests }\end{array}$} & \multicolumn{5}{|c|}{ Frequency } & \multirow{3}{*}{$\begin{array}{l}\text { Total } \\
\text { Respondente }\end{array}$} \\
\hline & $\begin{array}{l}\text { Strongly } \\
\text { Agrete }\end{array}$ & Agree & $\begin{array}{l}\text { lonile- } \\
\text { cided }\end{array}$ & $\begin{array}{l}\text { Dis- } \\
\text { agrete }\end{array}$ & $\begin{array}{l}\text { Strungly } \\
\text { Disagree }\end{array}$ & \\
\hline & $\underline{N} \quad(\%)$ & $\underline{N} \quad(\%)$ & N $\quad(\%)$ & $\underline{N} \quad(\%)$ & $\underline{N} \quad(\%)$ & \\
\hline
\end{tabular}

20. An acadernic nili ice supportive

$12 \quad(2.5 \%) \quad 87(18.3 \%) \quad 85(17.9 \%) \quad 184(38.7 \%) \quad 107(22.5 \%) \quad 475$

of the ine

of scholarstip.

21. A collesial relationship with alministration.

22. A formalized structure and prucess for insticutional decision-making.

23. A professional, rather than employee, status to the ir

24. An increaged interest in the funcision and role of the $f a c$ dity senate/council.

25. An intluence in setting inst t. Lutional standarda for academic performance.

26. Involvenent in the selection process for the appointenent of or jepartmental administrative postlion.

27. The right to paricicipation in policy makling on educat lonal is sues that have the potential to afrect public opinion about the

$11(2.3 \%) \quad 80(16.7 \%) \quad 67(14.0 \%) 202(42.3 \%) \quad 118(24.7 \%) \quad 478$

$52(11.0 \%) \quad 174(36.7 \%) \quad 78(16.5 \%) \quad 119(25.1 \%) \quad 51(10.8 \%)$

$19(4.1 \%) \quad 93(20.0 \%) \quad 85(18.3 \%) \quad 145(31.2 \%) \quad 123(26.5 \%)$

$14(2.9 \%) \quad 104(21.9 \%) \quad 81(17.0 \%) \quad 181(38.0 \%) \quad 96(20.2 \%) \quad 476$

$18 \quad(3.8 \%) \quad 117(24.5 \%) \quad 87(18.2 \%) \quad 162(34.0 \%) \quad 93(19.5 \%) \quad 477$

$21 \quad(4.4 \%) \quad 95(20.0 \%) \quad 81(37.1 \%) \quad 176(37.1 \%) \quad 101(21.3 \%)$

$28 \quad(5.9 \%) \quad 122(25.6 \%) \quad 90(18.9 \%) \quad 153(32.1 \%) \quad 84(17.6 \%)$ 


\section{APPENDIX K \\ TABLE XXXII: FACULTY MEMBERS' PERCEPTIONS OF THE IMPACT OF ACADEMIC COLLECTIVE BARGAINING ON ECONOMIC INTERESTS IN INSTITUTIONAL GOVERNANCE}


TABI.E XXXL1

FACULTY MEMUESS, PERCEPTIONS OF ACAUEMIC COL

.ECTIVE BAHLIAINING'S IMPACT ON ECONOMIC

\begin{tabular}{|c|c|c|c|c|c|c|c|c|c|c|}
\hline \multirow{2}{*}{\multicolumn{2}{|c|}{$\begin{array}{l}\text { Instilutlonal Governance } \\
\text { Econoric lnterests }\end{array}$}} & \multicolumn{8}{|c|}{ Frequency } & \multirow[b]{2}{*}{$\begin{array}{l}\text { Total } \\
\text { Respondents }\end{array}$} \\
\hline & & \multicolumn{2}{|c|}{$\begin{array}{l}\text { Strongly } \\
\text { Agre: } \\
\text { N }(\%)\end{array}$} & \multicolumn{2}{|c|}{$\underline{N}^{\text {ABrec }}(\%)$} & \multicolumn{2}{|c|}{$\begin{array}{l}\text { Unde- } \\
\text { cided } \\
N \quad(\%)\end{array}$} & $\begin{array}{l}\text { Dis- } \\
n^{\text {agree }}(\%)\end{array}$ & $\begin{array}{l}\text { Sirongly } \\
\text { Disagree } \\
\text { N } \quad(\%)\end{array}$ & \\
\hline 28. & $\begin{array}{l}\text { Provtded you wlili a high public } \\
\text { proflle regarding budgetary is- } \\
\text { sues in Oregon's system of high- } \\
\text { er education. }\end{array}$ & 19 & $(4.0 \%)$ & 107 & $(22.7 \%)$ & 81 & $(17.2 \%)$ & $193(41.0 \%)$ & $71(15.1 \%)$ & 470 \\
\hline 29. & $\begin{array}{l}\text { Clarified the problem of a low } \\
\text { faculcy salary ochedule in ore- } \\
\text { gon's system of higher education. }\end{array}$ & 46 & $(9.7 \%)$ & 169 & $(35.7 \%)$ & 59 & (12.5\%) & $135(28.5 \%)$ & $65(13.7 \%)$ & 474 \\
\hline 30. & $\begin{array}{l}\text { Increased the importance of the } \\
\text { budgetary/financial affairs com- } \\
\text { mittee's rote in univerglty bud- } \\
\text { get analysio and planning. }\end{array}$ & 16 & $(3.4 \%)$ & 150 & $(31.8 \%)$ & 137 & $(29.0 \%)$ & $129(27.3 \%)$ & $40 \quad(8.5 \%)$ & 472 \\
\hline 31. & $\begin{array}{l}\text { Strengtisened your input into } \\
\text { bliort-range universily budget } \\
\text { plamning and declsion-making. }\end{array}$ & 15 & $(3.2 \%)$ & 116 & $(24.6 \%)$ & 86 & $(18.2 \%)$ & $183(38.8 \%)$ & $72(15.3 \%)$ & 472 \\
\hline 32. & $\begin{array}{l}\text { Provided for your input into } \\
\text { llie long-range budgetary plan- } \\
\text { ning model of the univeralty. }\end{array}$ & 12 & $(2.6 \%)$ & 100 & $(21.2 \%)$ & 116 & $(24.6 \%)$ & $164(34.8 \%)$ & $79(16.8 \%)$ & 471 \\
\hline 33. & $\begin{array}{l}\text { Encouraged the untversity bud- } \\
\text { getary affairs comnitlee to link } \\
\text { universily budget plaming to the } \\
\text { ddentified instlcution's academic } \\
\text { goals. }\end{array}$ & 13 & $(2.8 \%)$ & 94 & $(20.1 \%)$ & 158 & $(33.8 \%)$ & $140(29.9 \%)$ & $63(13.5 \%)$ & 468 \\
\hline 34. & $\begin{array}{l}\text { Assisted the faculty and adminis- } \\
\text { tratlon to present a united agree- } \\
\text { ment to the stace legistature. }\end{array}$ & 23 & $(4.8 \%)$ & 138 & $(20.1 \%)$ & 119 & $(25.1 \%)$ & $128(27.0 \%)$ & $67(14.1 \%)$ & 475 \\
\hline 35. & $\begin{array}{l}\text { Cenerated additlonal money for the } \\
\text { university faculty salary schedule } \\
\text { in Oregon's syotem of higher educa- } \\
\text { inon. }\end{array}$ & 8 & $(1.7 \%)$ & 64 & $(13.5 \%)$ & 73 & $(15.4 \%)$ & $192(40.6 \%)$ & $136(28.8 \%)$ & 473 \\
\hline 36. & $\begin{array}{l}\text { Increased your salary and fringe } \\
\text { benefics packabe in the univer- } \\
\text { sity system. }\end{array}$ & 18 & $(3.8 \%)$ & 110 & $(23.2 \%)$ & 73 & $(15.4 \%)$ & $146(30.8 \%)$ & $127(26.8 \%)$ & 474 \\
\hline
\end{tabular}

